\title{
CARACTERIZAÇÃO DE RAÍZES DE MANDIOCA (Manihot esculenta Crantz) DO CULTIVAR IAC 576-70 QUANTO À COCÇÃO, COMPOSIÇÃO QUÍMICA E PROPRIEDADES DO AMIDO EM DUAS ÉPOCAS DE COLHEITA
}

\author{
Cristiane Mengue Feniman
}

\author{
Dissertação apresentada à Escola Superior de \\ Agricultura "Luiz de Queiroz", Universidade de São \\ Paulo, para obtenção do título de Mestre em Ciências, \\ Área de Concentração: Ciência e Tecnologia de \\ Alimentos.
}

P I R A C I C A B A

Estado de São Paulo - Brasil

Julho - 2004 


\section{CARACTERIZAÇÃO DE RAÍZES DE MANDIOCA (Manihot esculenta Crantz) DO CULTIVAR IAC 576-70 QUANTO À COCÇÃO, COMPOSIÇÃO QUÍMICA E PROPRIEDADES DO AMIDO EM DUAS ÉPOCAS DE COLHEITA}

\section{Cristiane Mengue Feniman}

Tecnólogo em Alimentos

Orientador: Prof ${ }^{\mathrm{a}}$. $\mathrm{Dr}^{\mathrm{a}}$. SILENE BRUDER SILVEIRA SARMENTO

Dissertação apresentada à Escola Superior de Agricultura "Luiz de Queiroz", Universidade de São Paulo, para obtenção do título de Mestre em Ciências, Área de Concentração: Ciência e Tecnologia de Alimentos.

P I R A C I C A B A

Estado de São Paulo - Brasil

Julho - 2004 


\section{Dados Internacionais de Catalogação na Publicação (CIP) DIVISÃO DE BIBLIOTECA E DOCUMENTAÇÃO - ESALQ/USP}

\section{Feniman, Cristiane Mengue}

Caracterização de raízes de mandioca (Manhiot esculenta Crantz) do cultivar IAC 576-70 quanto à cocção, composição química e propriedades do amido em duas épocas de colheita / Cristiane Mengue Feniman. - - Piracicaba, 2004.

$83 \mathrm{p}$.

Dissertação (mestrado) - - Escola Superior de Agricultura Luiz de Queiroz, 2004.

Bibliografia.

1. Amido-propriedade físico-químico 2. Cozimento 3. Época de colheita 4. Fibras vegetais 5. Mandioca 6. Pectina 7. Raiz I. Título

CDD 664.8052

\section{"Permitida a cópia total ou parcial deste documento, desde que citada a fonte - $\mathrm{O}$ autor"}


Aos meus queridos pais, Cesar e Lourdes, que sempre me amaram, perdoaram as minhas falhas, me incentivaram $e$ me apoiaram nesta jornada.

Aे minha querida irmã Greicy por me ouvir e me aconselhar nos momentos dificeis. 


\section{AGRADECIMENTOS}

A Deus, em primeiro lugar, por me guiar e sempre estar ao meu lado incondicionalmente.

Aos meus pais, Cesar e Lourdes, pelo amor, incentivo e dedicação, à minha irmã Greicy, ao meu cunhado Laércio e à minha querida sobrinha Gabriela por sempre estarem me apoiando.

Á Prof ${ }^{a}$. Dra . Silene Bruder Silveira Sarmento pelo disponibilização da orientação neste curso.

Á Prof ${ }^{a}$. Dr ${ }^{\mathrm{a}}$. Marina Moraes Dallaqua pela presteza e contribuição na realização das análises histoquímicas.

À Prof ${ }^{a}$. Dr ${ }^{\mathrm{a}}$. Marta Helena Fillet Spoto pela colaboração e auxílio na elaboração da análise sensorial e correção do trabalho.

Á Prof ${ }^{\mathrm{a}}$. Dr ${ }^{\mathrm{a}}$. Marney Pascoli Cereda pelas sugestões oferecidas.

À Carlota Borrali dos Anjos pela disposição, auxílio e realização nas análises laboratoriais e, principalmente, pela amizade e cuidado comigo.

Ao Luiz Carlos Rodrigues pela grande contribuição na arte gráfica.

À Escola Superior de Agricultura “Luiz de Queiroz”, Universidade de São Paulo, e Departamento de Ciência e Tecnologia de Alimentos por disponibilizar as instalações para a realização deste trabalho.

À CAPES pela concessão da bolsa de estudos.

Ao Centro Federal de Educação Tecnológica do Paraná - Unidade de Medianeira, responsável pela minha formação profissional e por me acolher durante a minha primeira experiência profissional. 
Às minhas queridas amigas Vanessa, Camila, Márcia Mayumi, Márcia D’Ávila, Claudia e Luciana que sempre estiveram ao meu lado me consolando e ajudando nas dificuldades, mas também compartilhando comigo os momentos alegres.

Aos meus queridos amigos da pós-graduação, Christiann, Nilo, Fabiana, Laurentina, Karina, Andréia e Rosane que juntos iniciamos esse desafio.

Aos meus colegas professores e amigos Marly, Janesca, Sônia, Milton, Cassiana, Marines, Ruth, Paulo, Margarida e Saraspathy pelo apoio, amizade e companheirismo. 


\section{SUMÁRIO}

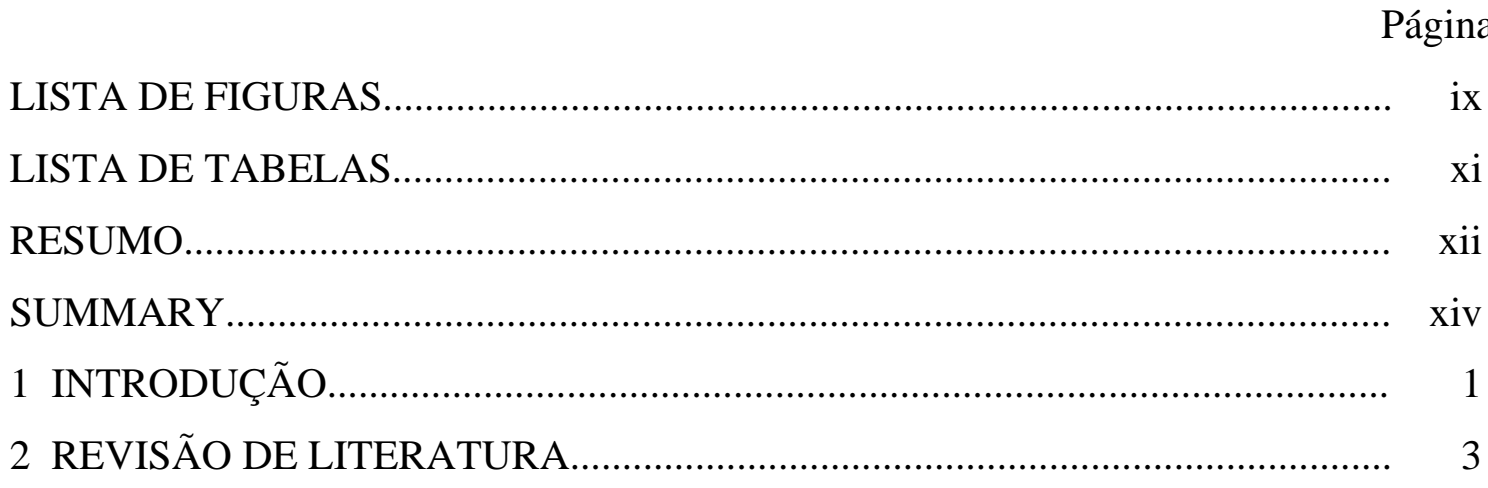

2.1 Características das raízes de mandioca.............................................................. 3

2.2 Carboidratos de reserva e estruturais dos vegetais.......................................... 4

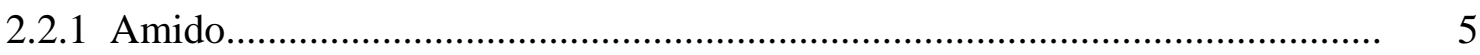

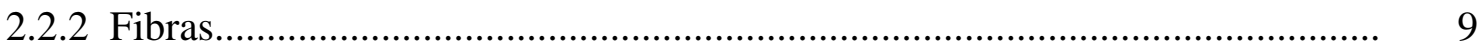

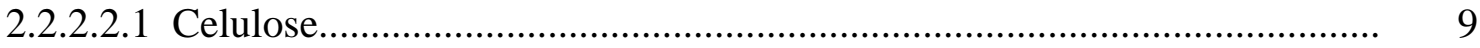

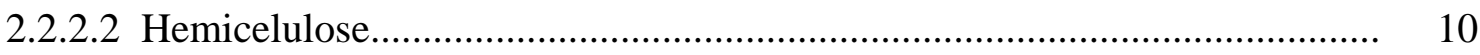

2.2.2.3 Substâncias pécticas.................................................................................. 10

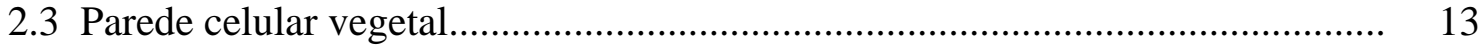

2.3.1 Lamela média................................................................................ 13

2.3.2 Parede celular primária............................................................................ 14

2.3.3 Parede celular secundária........................................................................ 16

2.3.4 Lignificação da parede celular................................................................ 17

2.3.5 Orientação da deposição da parede celular.................................................. 17

2.3.6 Pontoações da parede celular....................................................................... 17

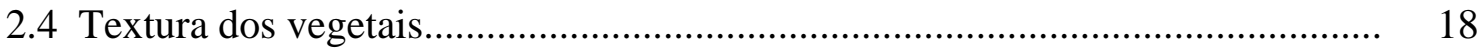

2.5 O cozimento de raízes de mandioca............................................................. 22 
2.6 Características de massa cozida de tuberosas.................................................. 24

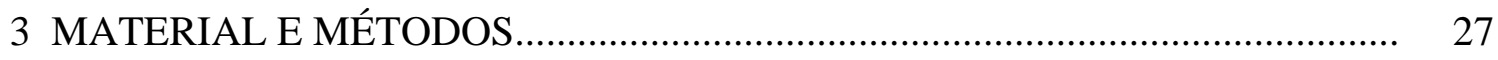

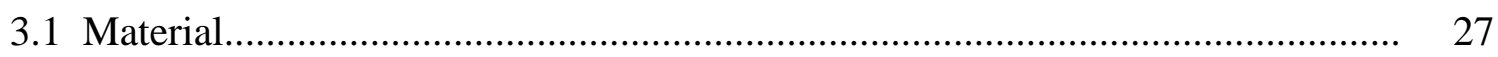

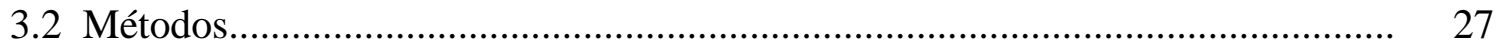

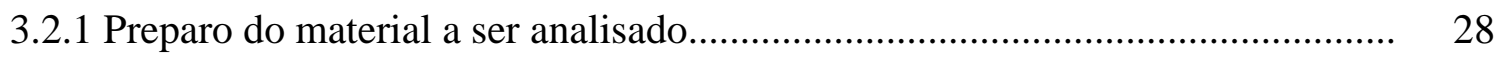

3.2.2 Composição da raiz in natura .................................................................. 30

3.2.2.1 Teor de umidade.................................................................................. 30

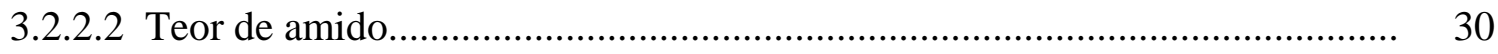

3.2.2.3 Teor de carboidratos redutores.............................................................. 30

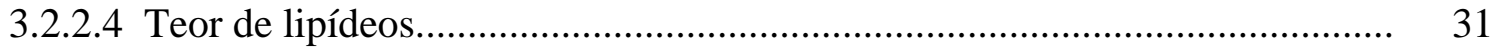

3.2.2.5 Teor de proteínas.................................................................................. 31

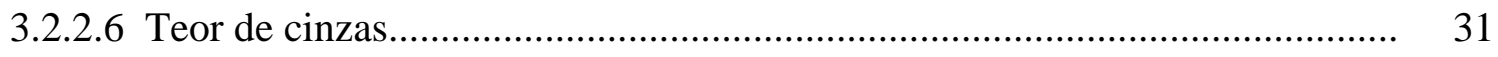

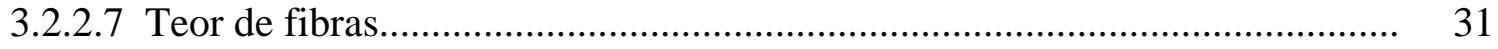

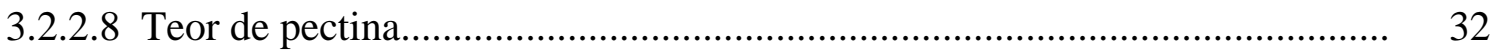

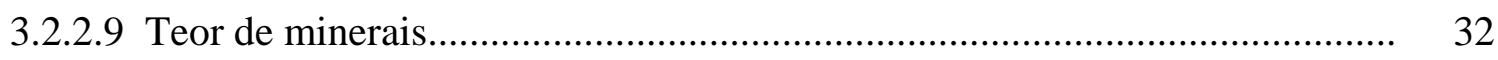

3.2.3 Tempo de cocção das raízes.......................................................................... 32

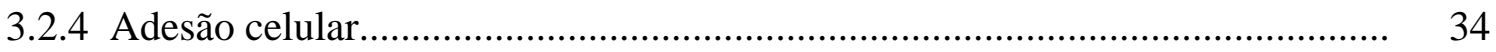

3.2.5 Avaliação histoquímica das raízes............................................................. 34

3.2.6 Textura das raízes quanto à resistência ao cisalhamento............................... 35

3.2.7 Avaliação das raízes congeladas.................................................................. 35

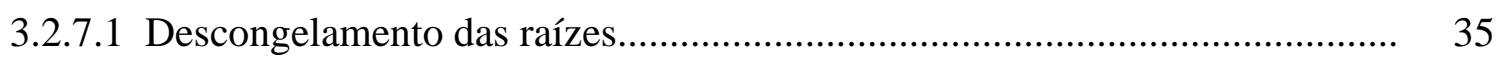

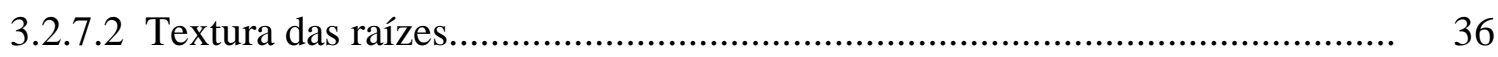

3.2.7.3 Análise sensorial das raízes....................................................................... 36

3.2.8 Extração e caracterização do amido.............................................................. 38

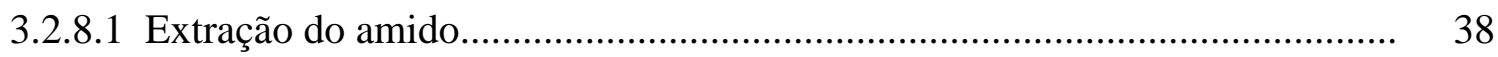

3.2.8.2 Teor de amilose aparente......................................................................... 38

3.2.8.3 Tamanho dos grânulos......................................................................... 38



3.2.9 Análise estatística................................................................................ 40

4 RESULTADOS E DISCUSSÃO.................................................................... 41 
4.1 Composição das raízes de mandioca.................................................................. 43

4.2 Características do amido............................................................................. 48

4.2.1 Teor de amilose aparente......................................................................... 49

4.2.2 Tamanho e formato dos grânulos de amido................................................... 50

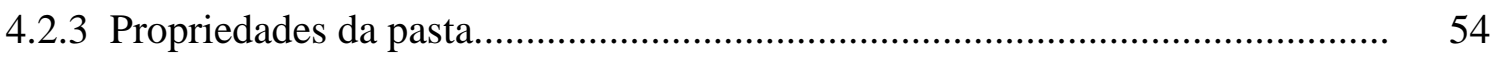

4.3 Tempo de cocção das raízes e adesão celular................................................... 56

4.4 Propriedades da pasta das raízes cozidas, desidratadas e moídas....................... 59

4.5 Avaliação histoquímica das raízes cruas e cozidas............................................ 61

4.6 Textura das raízes cruas e cozidas.................................................................... 66

4.7 Análise sensorial das raízes........................................................................ 70

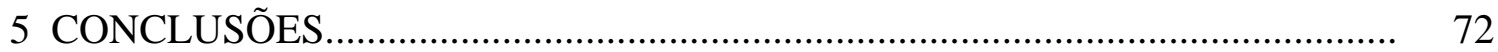

REFERÊNCIAS BIBILIOGRÁFICAS.............................................................. 74 


\section{LISTA DE FIGURAS}

Página

$1 \quad$ Estrutura da amilose (A) e amilopectina (B)............................................. 7

2 Representação esquemática do grânulo de amido......................................... 8

3 Representação esquemática dos níveis de estrutura que contribuem para as propriedades mecânicas dos tecidos vegetais............................................ 19

4 Representação esquemática de ruptura de tecido vegetal por (a) ruptura das células e (b) separação celular................................................................. 20

$5 \quad$ Esquema de análises utilizado no experimento........................................... 28

6 Aspecto do aparelho Mattson, modificado, utilizado para avaliar tempo de cocção das raízes de mandioca.................................................................. 33

7 Modelo da ficha utilizada na análise sensorial das raízes cozidas de

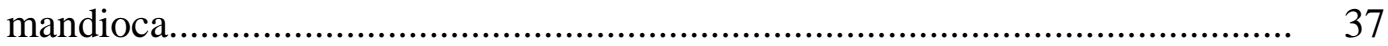

8 Curva típica do Rapid Visco Analyser (RVA).......................................... 40

9 Imagem dos grânulos de amido (aumento de 10 vezes) extraído de raízes de plantas de: 12 meses (A) e 15 meses (B)................................................. 50

10 Imagem dos grânulos de amido (aumento de 40 vezes) extraído de raízes de plantas de: 12 meses (A). 15 meses (B)................................................... 50

11 Histogramas para diâmetro menor dos grânulos de amido de raízes de plantas de mandioca com 12 e 15 meses.................................................... 52

12 Histogramas para diâmetro maior dos grânulos de amido de raízes de plantas de mandioca com 12 e 15 meses....................................................................... 53

13 Curvas viscoamilográficas obtidas pelo RVA para amidos extraídos de raízes do cultivar IAC 576-70, com 12 e 15 meses de idade. 
14 Perfis de viscosidade (RVA) das farinhas de raspas e das raízes cozidas, desidratadas e moídas, de plantas de mandioca aos 12 e aos 15 meses de idade

15 Secções transversais medianas da raiz adventícia de Manihot esculenta Crantz cultivar IAC 576-70, de plantas com 12 meses de idade, tuberizada. Aspecto geral do cilindro vascular em estrutura secundária. Vermelho de rutênio evidenciando pectina na parede celular (setas) de raízes cruas (A) e

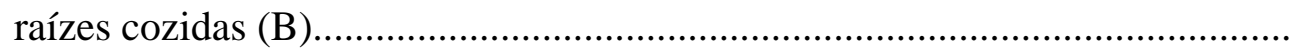

16 Secções transversais medianas da raiz adventícia de Manihot esculenta Crantz cultivar IAC 576-70, de plantas com 12 meses de idade, tuberizada. Aspecto geral do cilindro vascular em estrutura secundária. Floroglucina evidenciando parede celular secundária lignificada de elemento de vaso (setas). Raiz crua (A). Raiz cozida (B)

17 Secções transversais medianas da raiz adventícia de Manihot esculenta Crantz cultivar IAC 576-70, de plantas com 12 meses de idade, tuberizada. Aspecto geral do cilindro vascular em estrutura secundária. Cloreto férrico para a determinação de compostos fenólicos (coloração azul não evidenciada). Raiz crua (A). Raiz cozida (B)

18 Secções transversais medianas da raiz adventícia de Manihot esculenta Crantz cultivar IAC 576-70, de plantas com 12 meses de idade, tuberizada. Aspecto geral do cilindro vascular em estrutura secundária. Sudan IV evidenciando presença de lipídeos na parede celular de raiz crua e nas células de raiz cozida (setas). Raiz crua (A). Raiz cozida (B).

19 Curvas do texturômetro TA.XT2 para raízes de mandioca de plantas com 12 meses de idade

20 Curvas do texturômetro TA.XT2 para raízes de mandioca de plantas com 15 meses de idade 


\section{LISTA DE TABELAS}

Página

1 Temperaturas médias e pluviosidades mensais na região de Piracicaba - SP durante o desenvolvimento da cultura no campo........................................... 42

2 Composição centesimal das raízes de mandioca do cultivar IAC 576-70 aos 12 e aos 15 meses de idade

3 Componentes químicos da matéria-seca das raízes de mandioca do cultivar IAC 576-70 aos 12 e aos 15 meses de idade.

4 Teores de pectinas e de minerais em raízes de mandioca do cultivar IAC 57670, aos 12 e aos 15 meses de idade

5 Teores de pectinas e de minerais na matéria seca de raízes de mandioca, cultivar IAC 576-70, aos 12 e aos 15 meses de idade.

6 Tamanho dos grânulos de amido das raízes de plantas de mandioca do cultivar IAC 576-70, com 12 e 15 meses de idade.

7 Propriedades das pastas de amidos extraídos de raízes de plantas com 12 e 15 meses de idade.

8 Tempo ideal de cocção e adesão celular das raízes de mandioca do cultivar IAC 576-70 aos 12 e aos 15 meses de idade.

9 Propriedades da pasta de raízes de mandioca cruas, desidratadas e moídas e raízes cozidas, desidratas e moídas

10 Textura das raízes de mandioca de plantas do cultivar IAC 576-70 aos 12 e aos 15 meses de idade

11 Notas dos provadores pela escala hedônica para avaliação global das raízes cozidas de plantas com 12 e 15 meses de idade. 


\title{
CARACTERIZAÇÃO DE RAÍZES DE MANDIOCA (Manihot esculenta Crantz) DO CULTIVAR IAC 576-70 QUANTO À COCÇÃO, COMPOSIÇÃO QUÍMICA E PROPRIEDADES DO AMIDO EM DUAS ÉPOCAS DE COLHEITA
}

\author{
Autora: CRISTIANE MENGUE FENIMAN \\ Orientador: Prof ${ }^{\mathrm{a}}$. Dr ${ }^{\mathrm{a}}$. SILENE BRUDER SILVEIRA SARMENTO
}

\section{RESUMO}

A cocção é uma característica importante na seleção de um cultivar de mandioca para uso culinário, tanto pelo consumidor como pela indústria de produtos processados. No entanto, existem épocas em que raízes de mandioca apresentam problemas no cozimento, como o de textura da massa, ou ainda, cultivares com melhores ou piores características de cozimento, independente de quanto tempo dure o processamento. O objetivo do presente estudo foi caracterizar o cultivar IAC 576-70, o mais utilizado no Estado de São Paulo para fins culinários, em diferentes idades, quanto ao tempo de cocção das raízes e à qualidade das mesmas quando cozidas. Estes parâmetros foram relacionados com composição química e características histológicas das raízes e também com características físicas e físico-químicas do amido. As raízes desse cultivar, nas condições do estudo, apresentaram variabilidade no tempo de cocção com a idade ou período fisiológico do vegetal. As raízes de plantas com 12 meses, colhidas no mês de fevereiro (período vegetativo) apresentaram menor tempo de cocção que as raízes de plantas com 15 meses, colhidas no mês de maio (repouso fisiológico). Quanto à composição as raízes de plantas aos 12 meses apresentaram menores teores de amido e de fibras e maiores teores de carboidratos redutores, de pectina total, de 
proteínas e de lipídeos na massa seca que as plantas de 15 meses. Nas raízes de plantas aos 12 meses o amido apresentou grânulos de menor tamanho e com menor pico de viscosidade. A textura das raízes aos 12 meses apresentou menor resistência ao cisalhamento, maior percentual de desintegração e maior aceitabilidade pelos provadores na avaliação sensorial. Os testes histoquímicos das raízes de ambas as idades não revelaram diferenças entre si. 


\title{
CHARACTERIZATION OF CASSAVA (Manihot esculenta Crantz) ROOTS, IAC 576-70 CULTIVAR, REGARDING COOKING, CHEMICAL COMPOSITION AND STARCH CHARACTERISTICS AT TWO HARVEST TIMES
}

\author{
Author: CRISTIANE MENGUE FENIMAN \\ Adviser: Prof ${ }^{a}$. Dr ${ }^{\mathrm{a}}$. SILENE BRUDER SILVEIRA SARMENTO
}

SUMMARY

Cooking is an important characteristic for the selection of cassava cultivars, not only by end consumers, but also by food processing companies. Cassava roots present some cooking problems, such as poor texture characteristics, when harvested in certain periods of the year. Cultivars also show different cooking characteristics, regardless of the processing time. The present study was aimed at characterizing cassava roots, IAC 576-70 cultivar, the most used for cooking in Sao Paulo State, at different ages, as regards cooking times and quality after cooking. These two parameters were related to the chemical composition and histological characteristics of roots, as well as to physical and physicochemical characteristics of the starch. Under the conditions of the study, roots showed differences in cooking times, which varied with age or with the physiological stage of plants. Roots of 12-month-old plants harvested in February (vegetative period) showed shorter cooking times than roots of 15-month-old plants harvested in May (physiological rest). Roots of 12-month -old plants showed lower amounts of starch and fibers and larger contents of reducing carbohydrates, total pectin, 
protein and lipids in the dry matter than roots of 15-month-old plants. Twelve-monthold plants yielded roots with smaller starch granules, lower viscosity peak. Such roots also showed lower shear strength, higher disintegration percentage and higher approval by tasters during sensory tests. Histochemcial tests revealed no differences between 12month-old and 15-month-old roots. 


\section{INTRODUÇÃO}

A mandioca (Manihot esculenta C.) desempenha um importante papel na dieta alimentar dos brasileiros, por seu alto teor energético. O Brasil figura como um dos maiores produtores dessa cultura e também como grande consumidor, apresentando em 1999 um consumo de raízes per capita de $42,9 \mathrm{Kg} / \mathrm{hab} / \mathrm{ano}$, enquanto o consumo per capita mundial foi de apenas 16,4Kg/hab/ano (FAO, 2003).

A exploração agrícola dessa cultura destina-se ao mercado hortícola e às indústrias de transformação. A comercialização das raízes de mandioca para uso na alimentação humana se dá principalmente sob a forma in natura, ou seja, do uso direto. Entretanto, no Brasil é crescente o mercado de produtos de mandioca de uso culinário industrializados como a pré-cozida congelada, os produtos processados a partir da massa cozida, como croquetes, empanados, bolinhos condimentados e massas formatadas, como os palitos estruturados e ainda as fritas tipo chips. Esse aumento do consumo dos produtos semi-prontos e principalmente dos fast foods decorre de fatos como a migração da população para os grandes centros urbanos, o aumento da participação feminina no mercado de trabalho e a falta de tempo disponível para a preparação convencional dos alimentos de um modo geral.

O tempo de cozimento é uma característica importante na seleção de uma cultivar de mandioca para uso de mesa, tanto pelo consumidor como para a indústria de produtos processados. Além do tempo de cocção, a qualidade de massa cozida é fundamental. Essa qualidade é determinada por uma série de fatores os quais contribuem, em maior ou menor intensidade, para a boa aceitação do produto pelo consumidor. A plasticidade, por exemplo, permite moldar a massa cozida de acordo com a finalidade de utilização da mesma. 
Existem raízes de mandioca que apresentam problemas na cocção, demandando elevado tempo de cozimento ou, ainda, por mais extenso que seja esse tempo, não apresentam características de raiz totalmente cozida. Existem também períodos mais favoráveis à coç̧ão. O tempo de cozimento é decisivo na eleição de novas variedades, devido ao gasto de energia e por estar relacionado ao tipo de massa gerada. Geralmente, quanto mais tempo é gasto para cozer, pior é a qualidade da massa.

O tempo de cocção das raízes de mandioca e as características da massa cozida resultante constituem preocupação para o consumidor direto, que quer garantia do bom cozimento e para a indústria, que necessita definir parâmetros de processo, controlar a qualidade do produto final e a uniformidade do mesmo. Entretanto, poucos trabalhos são encontrados na literatura científica visando elucidar os mecanismos relacionados à maior ou menor dificuldade de cocção dessas raízes. O objetivo do presente estudo foi caracterizar o cultivar IAC 576-70, em raízes de plantas com 12 e 15 meses de idade, quanto ao tempo de cocção das raízes e relacionar esse tempo com parâmetros como composição química e características hitológicas das raízes, características físicas e físico-químicas do amido, textura e análise sensorial das raízes cozidas. 


\section{REVISÃO DE LITERATURA}

\subsection{Características das raízes de mandioca}

A mandioca é uma planta da família Euphorbiaceae e segundo MoraesDallaqua \& Coral (2002) a raiz adventícia dessa planta apresenta o padrão anatômico normal de desenvolvimento até o início do processo de tuberização, estabelecendo-se uma diferenciação maior de células parenquimáticas do xilema para o acúmulo de grãos de amido.

A planta de mandioca apresenta ciclo de desenvolvimento composto por cinco fases fisiológicas principais, sendo quatro ativas e uma de repouso vegetativo. $\mathrm{Na}$ primeira fase, chamada de brotação da maniva, sob condições favoráveis de umidade e temperatura, surgem as primeiras raízes fibrosas após o $7^{\circ}$ dia do plantio. $\mathrm{Na}$ segunda fase continua sendo formado o sistema radicular, constituído por raízes fibrosas, como o de qualquer outra planta. Esta fase tem duração aproximada de 70 dias. Na terceira fase ocorre o desenvolvimento da parte aérea e tem duração de 90 dias. Durante essa fase já ocorre simultaneamente o espessamento de algumas raízes fibrosas pelo acúmulo de amido. Ressalta-se que quanto mais tempo a folha da mandioca permanecer na planta, menor quantidade de produtos da fotossíntese será alocada na formação de novos ápices de crescimento e conseqüentemente mais energia poderá ser transportada para ser armazenada na raiz de reserva, que será traduzida em maior produtividade de amido. A quarta fase é o espessamento das raízes de reservas, que corresponde à migração das substâncias de reserva para as raízes de armazenamento que se inicia na fase anterior e acentua-se no $5^{\circ}$ mês. Nessa fase já não há mais crescimento das raízes em 
comprimento, mas em diâmetro, pela deposição do amido. Na quinta e última fase, a chamada fase de repouso, a planta perde a folhagem naturalmente, encerrando a sua atividade vegetativa, permanecendo apenas a migração das substâncias de reserva para as raízes. É durante essa fase que a planta de mandioca armazena o máximo de reserva de amido nas raízes. Recomeça após esse período de repouso uma nova fase de crescimento, quando é reiniciada a formação das ramas e folhas, que inicialmente acontece à custa do amido armazenado nas raízes e ramas durante a fase de crescimento anterior (Ternes, 2002).

As raízes de mandioca apresentam uma composição média de 68,2\% de umidade, $30 \%$ de amido, $2 \%$ de cinzas, 1,3\% de proteínas 0,2\% de lipídeos e 0,3 de fibras (Albuquerque et al., 1993). As raízes de mandioca são, portanto, essencialmente energéticas, apresentando elevados teores de carboidratos, principalmente polissacarídeos.

\subsection{Carboidratos de reserva e estruturais dos vegetais}

Alimentos contendo carboidratos como componentes majoritários são comuns em todas as dietas. Os carboidratos abrangem desde monossacarídeos, como glicose e frutose, até polissacarídeos de alto peso molecular, como a amilose e amilopectina do amido, e a celulose. Muitos dos polissacarídeos são compostos por um só tipo de monômero, como a amilose, amilopectina e celulose. Outros são compostos por diferentes monômeros, como as hemiceluloses. Os polissacarídeos são importantes na estrutura que proporciona textura desejável em muitos alimentos. Os carboidratos, particularmente os polissacarídeos, são susceptíveis a alterações degradativas, que muitas vezes ocorrem durante processamento. As maiores alterações químicas, com impacto na textura, durante o processamento de alimentos ricos em carboidratos, incluem a gelatinização do amido, a hidrólise de polissacarídeos e a ação de certas carboidrases (Lineback, 1986). 
Outra alteração química que pode ocorrer com o avanço da maturação nos vegetais e que reflete na textura é a lignificação, caracterizada pela impregnação de ligninas nos espaços interfibrilares da parede celular, aumentando a resistência mecânica, especialmente contra pressão, e simultaneamente promovendo a perda de elasticidade. Pela incrustação com lignina, também há a redução de passagem de água pelas paredes celulares (Nultsch, 2000).

\subsubsection{Amido}

A maior reserva de energia em todas as plantas é o amido, sendo abundante em sementes, raízes e tubérculos. De todos os polissacarídeos, o amido é o único produzido em pequenos agregados individuais, denominados grânulos. São sintetizados nas células de cada planta, adquirem tamanho e forma prescritos pelo sistema biossintético das plantas e pelas condições físicas impostas pelo contorno do tecido (Whistler \& Daniel, 1993).

A biossíntese do amido ocorre em uma organela subcelular especializada, o amiloplasto, que possui uma membrana lipoprotéica limitante. Dentro dos amiloplastos estão as enzimas que catalisam a biossíntese da amilose e da amilopectina. $\mathrm{O}$ material inicial para a biossíntese do amido é a sacarose, que é transportada dos tecidos fotossintéticos da planta em desenvolvimento para os órgãos de armazenamento. A formação das cadeias poliméricas do amido ocorre em uma matriz lipoprotéica e o amiloplasto em desenvolvimento contém materiais lipídicos e protéicos, ambos na membrana que constitui o envoltório do mesmo e nas membranas da matriz interna no interior dos mesmos. O desenvolvimento do grânulo de amido dentro do amiloplasto ocupa uma proporção crescente do volume até que, com o grânulo totalmente desenvolvido, o volume interno é completamente ocupado pelo amido (Galliard \& Bowler, 1987).

O tamanho e forma do grânulo variam de planta para planta, todos eles diferentes e de procedência reconhecida quando examinados ao microscópio. Todos os 
grânulos possuem um hilo, que constitui o centro de nucleação, ao redor do qual desenvolve-se o grânulo (Whistler \& Daniel, 1986). Os grânulos possuem regiões cristalinas e não cristalinas em camadas alternadas. As ramificações agrupadas de amilopectina ocorrem como feixes de dupla hélice. Essas estruturas, a partir de muitas regiões cristalinas pequenas nas camadas densas dos grânulos de amido, alterna-se com camadas amorfas (Whistler \& BeMiller, 1999).

O amido é constituído basicamente por amilose e amilopectina, que representam 97 a 99\% do peso seco do mesmo (Galliard \& Bowler, 1987). Segundo Blanshard (1987) esses dois componentes do amido diferem-se entre si, quanto ao peso molecular, ao grau de polimerização de suas cadeias e à disposição dos mesmos no interior do grânulo.

Segundo Galliard \& Bowler (1987) a amilose possui peso molecular de $10^{5}$ a $10^{6}$ e com um número de resíduos de glicose por molécula que varia de 500 a 5000 . É considerada essencialmente linear, com ligações glicosídicas a (1-4). Entretanto, segundo Whistler \& BeMiller (1999) pode ocorrer a presença de algumas ramificações na amilose, com ligações $\alpha(1-6)$ em 0,3 a $0,5 \%$ do total de ligações na molécula.

As moléculas de amilose tendem a formar estruturas helicoidais, existindo evidências de que a amilose apresenta-se com uma dupla hélice em solução e que pode existir nesse estado nos grânulos de amido (Whistler \& Daniel, 1993).

Durante o aquecimento do grânulo de amido em meio aquoso a amilose contribui na viscosidade da fase contínua da dispersão amido-água (Galliard \& Bowler, 1987). Durante esse processo, parte da amilose de menor peso molecular poderá ter passado à solução, tendo-se, então, um sistema em que não há mais água livre, pois estará totalmente ligada às cadeias de amilose e amilopectina, ou presa nos espaços entre os grânulos. A viscosidade do sistema aumenta até o máximo e a transparência também (Bobbio \& Bobbio, 1992).

A amilopectina é descrita por Whistler \& BeMiller (1999) como uma grande molécula altamente ramificada. As moléculas de amido desenvolvem-se a partir de uma única unidade de $\alpha$-D-glucopiranose ligada a uma molécula protéica iniciadora, a amilogenina. Outras unidades D-glucopiranosil são adicionadas seqüencialmente, 
doadas pelas moléculas de adenosina difosfato glucose para produzir uma cadeia de unidades $\alpha$-D-glicopiranosil unidas por ligações $\alpha$ (1-4). Além da enzima que aumenta o tamanho da cadeia, a enzima ramificadora está ativa. A enzima ramificadora precisa de uma cadeia linear de 40 a 50 unidades antes de transferir uma porção de cadeia, que se torna uma ramificação de ligação $\alpha$-D-(1-6), e depois disto, ambos os terminais não redutores podem continuar sendo alongados. Esses pontos de ligação das ramificações constituem 4 a $5 \%$ do total de ligações. A molécula de amilopectina é constituída por uma cadeia principal, chamada de cadeia $\mathrm{C}$, que possui um grupamento final não redutor e numerosas ramificações, chamadas de cadeias B, nas quais o terceiro tipo de cadeia, as cadeias A, são fixadas. A amilopectina está presente em todos os amidos conhecidos, constituindo em torno de $75 \%$ dos amidos mais comuns (Whistler \& BeMiller, 1999) e possui peso molecular de $10^{7}$ a $10^{9}$, dependendo de sua origem (Galliard \& Bowler, 1987).

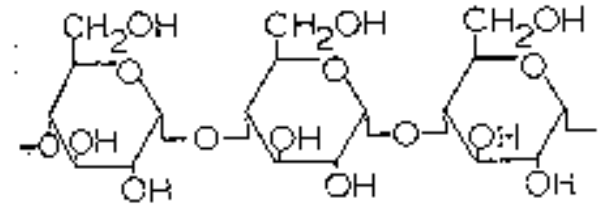

(A)

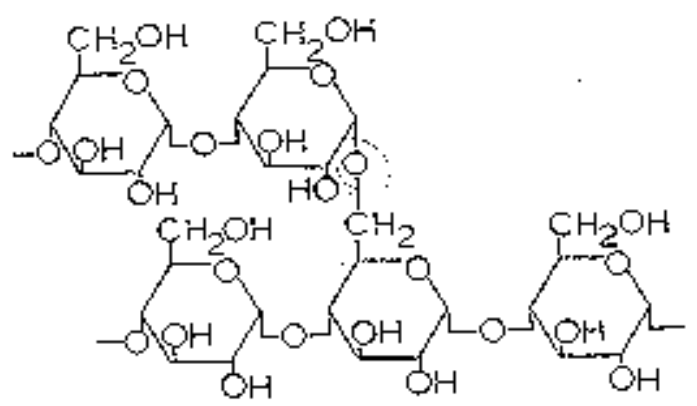

(B)

Figura 1 - Estrutura da amilose (A) e amilopectina (B)

Fonte: Whistler \& Daniel (1993)

Durante a cocção a amilopectina absorve muita água e é, em grande parte, responsável pela expansão do grânulo de amido. Assim, os grânulos ricos em amilopectina são mais fáceis de serem dissolvidos em água a $95^{\circ} \mathrm{C}$ que os que contêm muita amilose. Devido ao aumento esférico as moléculas de amilopectina não têm 
tendência à recristalização e, portanto, possuem elevado poder de retenção de água (Cheftel \& Cheftel, 1992).

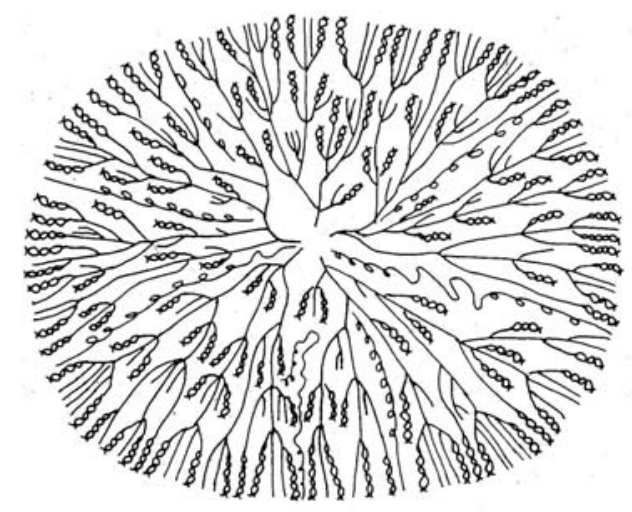

Figura 2 - Representação esquemática do grânulo de amido Fonte: Lineback (1986)

De acordo com Whistler \& Daniel (1993) os grânulos de amido intactos não são solúveis em água fria, mas podem reter pequenas quantidades de água de forma reversível, ocasionando um pequeno inchamento. Quando se aumenta a temperatura, as moléculas de amido vibram vigorosamente, rompendo as ligações intermoleculares e permitem a formação de pontes de hidrogênio com a água. A penetração de água e a separação progressiva de maiores segmentos de cadeias de amido aumentam ao acaso a estrutura geral e diminui o número de regiões cristalinas. Entretanto, segundo Bobbio \& Bobbio (1992) existem no grânulo zonas de maior resistência à penetração da água e a hidrólise, indicando regiões em que há maior número de ligações entre as moléculas.

$\mathrm{O}$ aquecimento contínuo em presença de água abundante resulta na completa perda de cristalinidade. $\mathrm{O}$ momento em que desaparece a birrefringência é conhecido como ponto ou temperatura de gelificação, que normalmente produz-se dentro de uma faixa de temperatura, gelificando primeiro os grânulos maiores e por último os menores. No estado nativo os grânulos não possuem membrana. Suas superfícies são formadas simplesmente por extremos de cadeias densamente empacotadas. Nas fases iniciais da gelificação aumenta-se a pressão interna no grânulo, conforme ocorre a entrada de água 
nas moléculas. Essa pressão provoca em algumas moléculas de amido a formação de uma membrana. As moléculas de amilose, lineares, são menos volumosas que as da amilopectina, ramificadas, e podem, na fase inicial do processo de gelificação, difundirem-se através da membrana superficial e passar à solução fora do grânulo (Whistler \& Daniel, 1993).

\subsubsection{Fibras}

As fibras referem-se ao total de polissacarídeos da planta, junto com a lignina, que são resistentes à hidrólise por enzimas digestivas do trato gastrintestinal. São formadas por componentes majoritários, tais como a celulose, a hemicelulose, a pectina e a lignina. Podem ser classificadas de acordo com suas relações com a estrutura das paredes celulares, de acordo com a sua natureza química (polissacarídeos não relacionados com o amido e polissacarídeos não relacionados com a celulose) e segundo a sua solubilidade em água, sendo que as fibras solúveis incluem pectinas, algumas hemiceluloses solúveis e polissacarídeos de reserva da planta. As fibras insolúveis compreendem celulose, lignina e algumas frações de hemiceluloses (Periago et al., 1993).

\subsubsection{Celulose}

O material que forma as paredes celulares das plantas é uma matriz complexa de celulose, lignina e hemicelulose. A celulose encontra-se presente em todas as plantas como principal componente estrutural das paredes celulares. Está normalmente associada a hemicelulose e lignina, sendo que o tipo e extensão dessas associações contribuem em grande parte com a textura característica dos vegetais. A celulose é uma homoglucana formada por cadeias lineares de unidades de (1-4)- $\beta$-D-glicopiranosil. A extrema linearidade da celulose promove forte associação das moléculas, de forma 
paralela, como ocorre extensivamente na celulose vegetal nativa. Suas moléculas possuem regiões amorfas e cristalinas, sendo que as regiões amorfas são mais facilmente atacadas por solventes e reagentes químicos (Whistler \& Daniel, 1993).

O calor úmido reduz a cristalinidade da celulose por inchamento e penetração de água entre as cadeias. As fibras ou fibrilas de celulose, numerosas cadeias de celulose associadas, são extremamente resistentes ao estiramento e praticamente insolúveis na maioria dos solventes (Cheftel \& Cheftel, 1992).

\subsubsection{Hemicelulose}

As hemiceluloses são uma classe de polímeros que se distinguem por produzirem, ao serem hidrolizadas, uma série de pentoses, ácidos glucurônicos e algumas formas de desoxi-açúcares. As inter-relações entre os componentes da parede celular não são conhecidas com detalhes, mas sabe-se com segurança que existem ligações físicas e covalentes entre eles. A hemicelulose mais abundante em alimentos possui uma cadeia principal do tipo xilano composto por unidades $(1 \rightarrow 4)-\beta$-Dxilopiranosil. Esse polímero contém freqüentemente cadeias laterais de $\beta$-Larabinofuranosil unidos na posição 3 de algumas unidades D-xilosil. Outros constituintes típicos são o 4-O-metil-éster do ácido D-glucurônico, D-galactose e grupos acetil-éster (Whistler \& Daniel, 1993).

\subsubsection{Substâncias pécticas}

As substâncias pécticas são polímeros compostos principalmente de unidades de $(1 \rightarrow 4)$ - $\alpha$-D-galacturonapiranosil encontradas nas lamelas médias das células vegetais. Alguns galactanos e arabinanos incluem-se nesta definição (Whistler \& Daniel, 1993). 
Brett \& Waldron (1996) descrevem os polissacarídeos mais representativos desse grupo:

$\checkmark$ Ramnogalacturonana 1 (RG I):consiste de uma cadeia de resíduos de ácido galacturônico unidos por ligações $\alpha-1,4$, e resíduos de ramnose unidos por ligações $\alpha-1,6$. A RG I contém também resíduos de arabinose e galactose unidos ao carbono 4 da ramnose. Esses resíduos formam as cadeias laterais. As hidrolixas dos resíduos da RG I podem ser esterificadas por grupamentos metil ou acetil.

$\checkmark$ Homogalacturonana: consiste em uma cadeia de resíduos de ácido galacturônico unidos por ligações $\alpha-1,4$, com variação no grau de esterificação. Quando a cadeia apresenta baixo nível de metilesterificação nos resíduos de ácido galacturônico, é referida como ácido péctico. Já quando a cadeia apresenta um alto grau de metilesterificação é denominada de ácido pectínico ou pectina. A homogalacturonana, caracterizada por conter pequena proporção, ou presença praticamente inexistente, de resíduos de ramnose, pode também estar unida à RG I.

$\checkmark$ Arabinana: possui cadeia altamente ramificada, cujo esqueleto é formado por resíduos de arabinose unidos por ligações $\alpha-1,5$.

$\checkmark$ Galactana: os resíduos de galactose são unidos por ligações $\beta$-1,4 e constituem a cadeia principal. Possui algumas ramificações de ácidos galacturônico e glucurônico unidos no carbono 6.

$\checkmark$ Arabinogalactana: formada quando as cadeias laterais, unidas à cadeia de galactose, são compostas por cadeias curtas de arabinose.

Um dos aspectos que diferencia as pectinas entre si, portanto, é o seu conteúdo de ésteres metílicos (ou grau de esterificação). O grau de esterificação é definido como o número de resíduos de ácido D-galacturônico esterificados sobre o total de resíduos desse ácido, expressos em porcentagem. A pectina, por exemplo, possui um grau de esterificação de 50\%. A protopectina é a substância péctica presente na polpa dos frutos não maduros. Os ácidos pectínicos são substâncias pécticas menos metiladas que a protopectina e derivam-se dessa por ação de protopectinases e pectina 
metilesterase. Dependentemente do grau de polimerização e da metilação os ácidos pectínicos podem ser coloidais ou solúveis em água. Os ácidos pectínicos solúveis são conhecidos como pectinas de baixa metoxilação. A ação completa da pectinametilesterase sobre tais ácidos conduz à eliminação total dos grupos metilésteres, dando lugar aos ácidos pécticos. As enzimas pécticas contribuem com o desenvolvimento de textura desejável que se produz no fruto durante a maturação. Ao longo desse período, a protopectinase converte a protopectina em pectina coloidal ou em ácidos pectínicos solúveis. A pectina metilesterase elimina grupos metiléster da pectina para produzir ácido poli-D-galacturônico e o ácido péctico, que pode ser degradado a monômeros de ácido D-galacturônico pela poligalacturonase. Essas três enzimas atuam durante a maturação e são cruciais para determinar a textura dos vegetais (Whistler \& Daniel, 1993).

No vegetal, as pectinas e os ácidos pectínicos, uma vez liberados de suas ligações com a celulose, podem ser degradadas por dois processos diferentes, a despolimerização e a desesterificação. $\mathrm{Na}$ despolimerização, o aquecimento em meio ácido ou a ação de hidrolases, como pectinases, poligalacturonases, polimetilgalacturonases, pectino-hidrolases, originam o rompimento da cadeia, em partes mais curtas. $\mathrm{O}$ pH ótimo para essas enzimas pectinolíticas situa-se em torno de 4,0. O rompimento acontece em resíduos de ácido galacturônico não metilados, quando não há ação da polimetilgacturonase, pois as enzimas dessa classe são as únicas capazes de atacar uma cadeia péctica metilada artificialmente com 100\% de eficiência. Os íons cálcio são capazes de ativarem a ação de algumas poligalacturonases. $O$ outro processo de degradação de substâncias pécticas, a desmetilação, ocorre mediante ação de álcalis a frio ou pela ação da pectinametilesterase, como pectases e pectina metoxilases, que têm efeito de desmetilar a pectina e transformá-la em ácido péctico insolúvel em água. O aquecimento em meio ácido também pode efetuar a desmetilação, pois promove a fragmentação da cadeia poligalacturônica. As pectinametilesterases são específicas e só atuam nas proximidades de um resíduo galacturônico não metilado. Existem dois grupos de pectinametilesterases, as que são insolúveis, ligadas a estruturas celulares e que atuam sobre a protopectina em $\mathrm{pH}$ ótimo próximo a 7,5 e inativadas em $\mathrm{pH}$ abaixo de 
4,5, e as que são solúveis, que atacam as pectinas em solução, em pH ótimo de 7,5 e que seguem ativas em meio ácido (Cheftel \& Cheftel, 1992).

\subsection{Parede celular vegetal}

Parede celular vegetal é definida por Bruce et al. (1997) como sendo a matriz extracelular elaborada que envolve cada célula em um vegetal. São geralmente espessas e rígidas, podendo ter vários micrômetros de espessura.

A composição pode variar dependendo da espécie, estágio de desenvolvimento e diferenciação de célula e tecido da planta (Brownleader et al., 1999). Assim como a composição, as propriedades também são afetadas pelo ambiente, nutrição e estágio de diferenciação da célula. Essas propriedades influenciam características dos vegetais como a textura e a qualidade de cozimento (Cutter, 2002).

Uma parede celular íntegra e desenvolvida, de acordo com Sterling (1963), pode ser considerada viva quando for composta por três camadas que diferem uma das outras em virtude da topografia, ontogenia e estrutura.

\subsubsection{Lamela média}

A lamela média é a camada cimentadora comum entre células. Essa camada é formada durante a divisão celular e as células dessa camada são as primeiras a se dividirem para a formação de duas células filhas (Sterling, 1963).

Algumas pectinas são especialmente abundantes na lamela média e as ligações cruzadas causadas pelo cálcio auxiliam a manter os componentes da parede celular unidos. Assim, a dissociação de vários tecidos vegetais em suas células constituintes pode ser alcançada pelo tratamento com agentes quelantes de cálcio (Bruce et al., 1997). Entretanto, quando o cálcio é extraído dos tecidos, a maceração não é completa. 
Provavelmente, outras ligações podem estar fortalecendo o conjunto de células (Sterling, 1963).

Outro fator que mantém a integridade da lamela média é o grau de esterificação da pectina, sendo que a firmeza da estrutura celular pode ser afetada pela desesterificação das substâncias pécticas na lamela média (Bartolome \& Hoff, 1972).

\subsubsection{Parede celular primária}

Adjacente à lamela média há depósitos celulares que formam uma camada com elevado grau de organização, a parede primária. Essa camada é geralmente mais delgada, e forma-se logo abaixo da lamela média, enquanto a célula ainda está alongando-se. É birrefringente em luz polarizada e a estrutura organizada é também detectada por difração de raios X e por microscopia eletrônica (Sterling, 1963).

A parede primária é composta de celulose, hemicelulose e outros polissacarídeos (Cutter, 2002).

Em relação à parede celular primária Brownleader et al. (1999) reconhecem duas fases básicas, a fase microfibrilar, que compreende as microfibrilas celulósicas responsáveis pela estrutura principal da parede celular, e a fase matriz, constituída por polissacarídeos não celulósicos, fenóis e proteínas, que envolve e encaixa a estrutura de celulose.

A fase microfibrilar é distinguível da fase matriz pelo seu alto grau de cristalinidade e por apresentar relativa homogeneidade em sua composição química. Já a fase matriz é também chamada de fase não cristalina e é constituída de hemiceluloses, pectinas, proteínas e compostos fenólicos. Essa fase apresenta composição variável em virtude das partes da parede, dos tipos de células, das espécies e dos estágios do ciclo celular (Brett \& Waldron, 1996).

A celulose na fase microfibrilar é uma cadeia linear de polissacarídeos contendo de 3000 a 5000 resíduos de D-glucose unidos por ligações $\beta$ - $(1 \rightarrow 4)$ formando uma estrutura em forma de fita (Brownleader et al., 1999). Essa fita é estabilizada por 
pontes de hidrogênio dentro da cadeia. As cadeias de celulose são ligadas também por pontes de hidrogênio, o que promove uma adesão mais forte entre as cadeias, que são sobrepostas e dispostas paralelamente, formando um feixe de 60 a 70 cadeias de celulose, todas com a mesma polaridade. Estes agregados cristalinos altamente organizados, com vários micrômetros de comprimento, são chamados de microfibrilas de celulose. Grupos de microfibrilas são organizados em camadas ligadas por longas moléculas de hemicelulose. As moléculas de hemicelulose são ligadas por pontes de hidrogênio à superfície das microfibrilas. Várias destas camadas dispostas em uma rede conglomerada consistem na parede celular primária (Bruce et al., 1997).

As hemiceluloses são um grupo heterogêneo de polissacarídeos ramificados de várias classes, mas todas elas contêm uma cadeia principal longa e linear composta por um tipo de monômero e desta, projetam-se pequenas cadeias laterais de outros monômeros (Bruce et al., 1997). As hemiceluloses da parede celular primária são principalmente xiloglucanas. Sua cadeia principal é constituída de unidades de glucose unidas por ligações $\beta-(1 \rightarrow 6)$. Alguns resíduos de glicose podem ser substituídos por dissacarídeos ou trissacarídeos compostos por xilose, galactose, frutose e arabinose (Brownleader et al., 1999).

Tanto o monômero da cadeia principal como os da cadeia lateral variam de acordo com a espécie das plantas e seu estágio de desenvolvimento. São as moléculas de açúcar na cadeia principal que formam as pontes de hidrogênio com as microfibrilas de celulose. Essa rede de microfibrilas de celulose e hemicelulose é intercruzada por outra rede de polissacarídeos composta basicamente de pectinas. As pectinas são um grupo heterogêneo de polissacarídeos ramificados que contêm várias moléculas de ácido galacturônico carregadas negativamente, o que as tornam altamente hidratadas e acompanhadas por uma nuvem de cátions (Bruce et al., 1997).

Os polissacarídeos pécticos podem se ligar covalentemente a outro e a alguns compostos fenólicos, celuloses e proteínas do interior da parede celular primária. Os blocos estruturais das pectinas são essencialmente representados por ácido Dgalacturônico, L-rhamnose e D-galactose em variadas proporções dependendo de sua origem. Outros açúcares têm também sido encontrados nas pectinas, participando como 
D-xilose, 2-O-metil-L-frutose, D-apiose e ácido D-glucurônico. Já os componentes fenólicos da parede celular primária são compostos principalmente por ácido ferúlico e ácido p-ciumárico, sendo a base muito esterificada por resíduos de arabinose e galactose de polissacarídeos pécticos. Podem também ser identificadas glicoproteínas ricas em prolina, proteínas ricas em glicina e proteínas arabinogalactanas. Encontra-se também algumas enzimas, como as peroxidases, fosfatases, glicosil-hidrolases e algumas desidrogenases. As partes protéicas insolúveis encontram-se no interior da parede (Brownleader et al., 1999).

\subsubsection{Parede celular secundária}

Nas células novas a parede celular é denominada primária e apresenta-se fina e apenas semi-rígida, capaz de acomodar o crescimento celular subseqüente. Após a etapa de crescimento, a parede celular primária não necessita mais ser expandida, passando a ser retida. A célula passa a produzir uma parede rígida, a parede celular secundária, através do aumento da parede primária ou pela deposição de novas camadas de composição diferente abaixo das camadas já existentes (Bruce et al., 1997). Assim como a parede primária, a parede secundária é constituída de celulose, hemicelulose e outros polissacarídeos. Outras substâncias, como a lignina, podem também ser depositadas (Cutter, 2002).

Normalmente três camadas bem definidas chamadas de $S_{1}, S_{2}$ e $S_{3}$ para as camadas externa, mediana e interna, respectivamente, podem ser distinguidas na parede secundária (Raven et al., 2001).

A parede secundária tem como função aumentar a resistência particularmente em células especializadas e naquelas envolvidas na condução de água. Nessas células, o protoplasto morre após a parede secundária ter sido depositada (Raven et al., 2001). Citam-se os esclerócitos, fibras e elementos de vasos (Cutter, 2002). 


\subsubsection{Lignificação da parede celular}

Outro importante constituinte das paredes de muitos tipos de células é a lignina, que fornece resistência à compressão e rigidez à parede celular. A lignina é comumente encontrada em paredes de células vegetais que têm uma função mecânica ou de sustentação. Ela é hidrofóbica, substituindo a água na parede celular. O processo de lignificação inicia-se na substância intercelular, junto às extremidades das células, e então se estende para as primeiras camadas celulares formadas e finalmente para aquelas formadas posteriormente (Raven, et al., 2001).

A lignificação efetua-se pela impregnação de ligninas nos espaços interfibrilares da parede celular, aumentando a resistência mecânica, especialmente contra pressão, e simultaneamente promovendo a perda de elasticidade. Pela incrustação com lignina, também há a redução de passagem de água pelas paredes celulares (Nultsch, 2000).

\subsubsection{Orientação da deposição da parede celular}

A orientação das microfibrilas de celulose dentro da parede primária influencia a direção da expansão celular. Quando as microfibrilas de celulose estão aleatoriamente orientadas nas paredes, a célula se expandirá igualmente em todas as direções, tendendo a adquirir a forma esférica. Quando as microfibrilas estão orientadas em ângulos retos em relação ao maior eixo da célula, a célula se expandirá longitudinalmente ao longo desse eixo (Raven et al., 2001).

\subsubsection{Pontoações da parede celular}

Normalmente as paredes primárias das células não têm espessamento uniforme, apresentando áreas mais finas chamadas campos de pontoação primários. 
Filamentos citoplasmáticos ou plasmodesmos apresentam-se comumente agregados nos campos de pontoação primários. Os plasmodesmos são cordões citoplasmáticos que atravessam a parede celular, interligam os protoplastos de células adjacentes fornecendo uma via para o transporte de substâncias entre as células (Raven et al., 2001).

Quando a parede secundária não é depositada sobre os campos de pontoação da parede primária, interrupções características ou pontoações são formadas na parede secundária. Paredes secundárias não são permeáveis à água, mas com a formação de pontoação, pelo menos nesses sítios, as células adjacentes são separadas somente pelas paredes primárias. Uma pontoação em uma parede celular usualmente ocorre oposta a uma pontoação na parede de uma célula adjacente. A lamela média e as duas paredes primárias entre as duas pontoações são chamadas de membrana da pontoação (Raven et al., 2001).

\subsection{Textura dos vegetais}

O conceito de textura para o consumidor significa o grau de aceitabilidade em função do produto ser macio ou não, suculento ou não. Do ponto de vista técnico, textura é a soma das sensações cinestésicas derivadas da degustação de um alimento, englobando as sensações percebidas na cavidade oral, as propriedades mastigatórias, residuais e acústicas, ou ainda é a reação do alimento frente à aplicação de força (Campos, 1989).

A textura dos vegetais depende do arranjo das células juntamente com os espaços intercelulares que compõem os tecidos, ou seja, da organização estrutural. Damião Filho (1993) cita como exemplo dessa organização estrutural o tecido parenquimático, rico em substâncias de reserva, que possui variação no formato das células, mas geralmente são poliédricas e possuem apenas a parede celular primária.

Segundo Waldron et al. (1997) o conjunto de tecidos resulta em um determinado órgão, tais como frutos, raízes ou folhas, com características particulares da sua funcionalidade. A estrutura hierárquica mostrada na Figura 3 ilustra o elevado grau 
de complexidade dos tecidos vegetais e demonstra que não se pode aplicar modelos simplistas para entender seu comportamento frente a determinadas condições físicas e químicas.

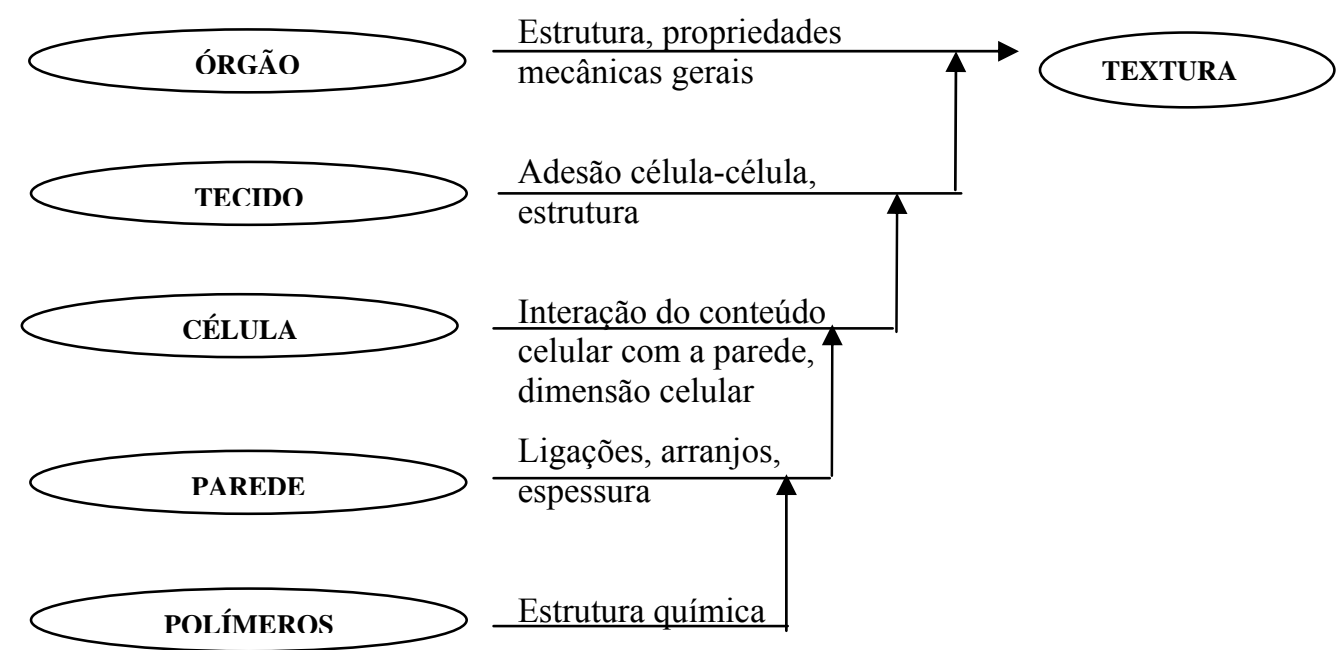

Figura 3 - Representação esquemática dos níveis de estrutura que contribuem para as propriedades mecânicas dos tecidos vegetais

Fonte: Waldron et al. (1997)

Quando o vegetal perde a integridade dos tecidos, deixa de refletir uma estrutura organizada e aproxima-se da estrutura apresentada por um tecido macio, composto por muitas células individualizadas e/ou rompidas (Favaro, 2003). Essa é a característica de vegetais cozidos e frutos macios, cuja textura é considerada farinácea ou mealy (Figura 4).

O processamento de vegetais pelo calor é geralmente acompanhado pelo amolecimento do tecido vegetal. O branqueamento e a esterilização afetam os tecidos vegetais pela destruição da pressão de turgor, expansão das paredes celulares e a maceração do tecido. Como resultado, a textura dos vegetais processados pode ser atribuída muitas vezes à perda de integridade estrutural da parede celular e da lamela média (Stolle-Smits et al., 1997). 
(a) crocante

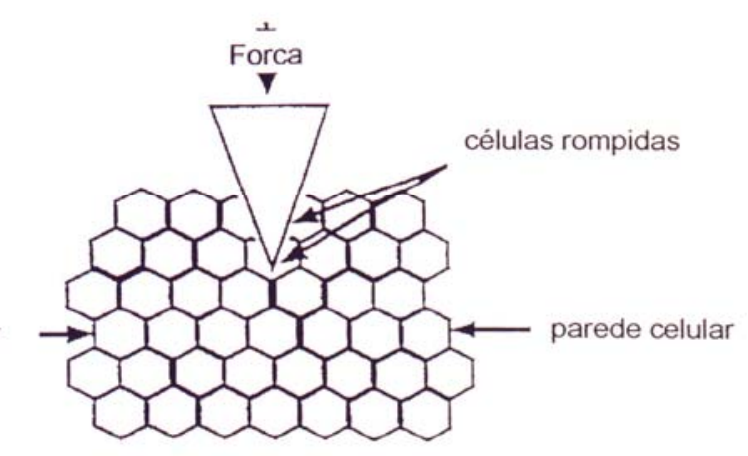

(b) maciol"mealy"

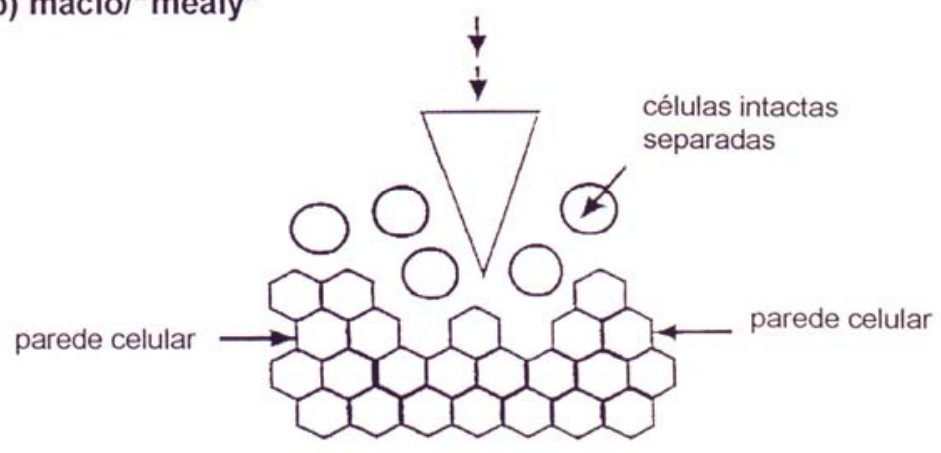

Figura 4 - Representação esquemática de ruptura de tecido vegetal por (a) ruptura das células e (b) separação celular

Fonte: Favaro (2003)

A textura dos tecidos vegetais decorre principalmente das características da parede celular. Conseqüentemente, há muito interesse em compreender os efeitos do processamento térmico na química dos polímeros da parede celular em relação à textura do produto final (Ng \& Waldron, 2002). O amolecimento termicamente induzido do tecido de vegetais conduz, principalmente, a um aumento da separação celular. Essa separação ocorre devido a destruição parcial do gel péctico que se forma na matriz da parede celular, com conseqüente perda de adesividade intercelular na lamela média. Esse efeito é acompanhado por aumento na solubilidade de polissacarídeos pécticos, provavelmente em conseqüência da degradação dos mesmos por $\beta$-eliminação e de alterações na distribuição de íons (Binner et al., 2000; Ng \& Waldron, 2002). 
As pontes de hidrogênio das substâncias pécticas são propensas ao rompimento quando submetidas ao aquecimento. Esse fato, em adição ao efeito da despolimerização péctica durante a cocção, tem como conseqüência a expansão e a solubilização das substâncias pécticas, promovendo a maciez dos tecidos, causada pela perda de integridade da lamela média (Sterling, 1963). Linehan \& Hughes (1969) observaram que a degradação de substâncias pécticas está associada à perda de adesão celular.

A pectina determina a porosidade e a espessura da parede celular e participa da importante função de manutenção da integridade do tecido. No processamento de batatas o material péctico é degradado e parcialmente solubilizado no meio de cocção. Essa degradação influencia amplamente a adesão intercelular e a estrutura da parede celular remanescente, tornando-as parâmetros importantes de textura. Três tipos de polissacarídeos pécticos estão presentes em todas as paredes celulares primárias de vegetais, a saber, homogalacturonano, ramnogalacturonano I e II. Entretanto, pouco é conhecido das pequenas diferenças na estrutura e composição dos polissacarídeos pécticos com respeito ao desenvolvimento de textura durante o processamento (Marle et al., 1997).

Segundo Stolle-Smits et al. (1995) a pectina da parede celular consiste de duas regiões distintas, uma linear de homogalacturonanos e uma ramificada de ramnogalacturonanos. Há evidências de ligações cruzadas covalentes em pectinas via ligações ésteres, conectando cada molécula de pectina, hemicelulose, celulose ou proteína. Sugere-se que algumas dessas ligações sejam pontes entre moléculas de pectinas adjacentes. A pectina está conectada na parede apenas pela sua habilidade de formar géis não covalentes intermediados pelo cálcio. A maior reação de quebra que conduz ao amolecimento do vegetal é a despolimerização por $\beta$-eliminação da pectina intercelular. $\mathrm{O}$ aumento do conteúdo de grupamentos metil éster na molécula resulta em maior grau de degradação péctica. Entretanto, possíveis modificações de constituintes menores, mas importantes, da parede celular, permanecem amplamente desconhecidas.

Bhatty (1995) observou que cultivares de lentilhas que apresentaram menores tempos de cocção foram as que apresentaram teores mais elevados de ácido fítico. O 
autor atribui essa associação à ação quelante do ácido fítico sobre os cátions bivalentes, $\mathrm{Ca}^{++}$e $\mathrm{Mg}^{++}$, impedindo a formação de pectatos insolúveis, formados a partir das substâncias pécticas. Como os pectatos evitam a desagregação celular durante o cozimento houve, conseqüentemente, uma redução da firmeza dos tecidos vegetais.

Normalmente, os tecidos que possuem parede celular secundária ou sofrem lignificação da parede não se tornam macios pela maturação ou pela cocção. No entanto, alguns tecidos parenquimáticos, cuja característica é a de possuírem parede pouco espessa e não lignificada, além de alto teor de amido, conservam a textura firme ou amaciam lentamente durante a cocção, como é o caso da parte comestível da monocotiledônea chinese water chestnut (Parker \& Waldron, 1995).

\subsection{0 cozimento de raízes de mandioca}

A qualidade da cocção de um vegetal é afetada por muitos fatores. Entre esses, podem ser citados a variedade, as condições de cultivo e as condições ambientais durante o crescimento, as condições de estocagem e os métodos de processamento (Safo-Kantanka \& Owsu-Nipah, 1992). De acordo com Valetudie et al. (1999) os produtos cozidos apresentam grande diversidade de propriedades estruturais, sensoriais e funcionais, de acordo com o método e a intensidade de processamento.

Lorenzi (1994) classifica os fatores que influenciam o tempo de cozimento da mandioca como intrínsecos e extrínsecos. São considerados fatores intrínsecos as variações dentro e entre raízes de uma mesma planta e entre plantas da mesma variedade. A influência desses fatores é gerada pelos processos fisiológicos de crescimento, acúmulo e mobilização de substâncias na raiz, que interferem na variação de composição tanto no eixo radial quanto no longitudinal, expondo diferenças na qualidade de massa cozida ao longo da raiz. Já os fatores extrínsecos estão relacionados à variação do genótipo, das condições ambientais, como o tipo de solo, e do estado fisiológico das plantas, como a idade das mesmas na época de colheita. Apesar da mandioca ser uma cultura de ciclo longo e não ter época definida de maturação há 
períodos, especialmente entre o final do primeiro e o início do segundo ciclo vegetativo, de maior estabilidade na produção e na composição das raízes e que normalmente coincidem com as melhores épocas de colheita em relação à qualidade de cocção.

Normanha (1988) sugere que o não cozimento pleno das raízes de mandioca seja devido, principalmente, a fatores que não permitem o rompimento completo das ligações entre moléculas de derivados pécticos que unem a lamela média às paredes primárias das células e aos demais elementos do parênquima. De acordo com esse autor a mandioca é considerada cozida quando a polpa for facilmente esmagada, desfeita, quando amassada com o garfo, até o ponto de purê, e ficar como uma pasta moldável, plástica. Na cocção das raízes de mandioca o calor gerado pela temperatura de ebulição da água, em torno de $98^{\circ} \mathrm{C}$, catalisa ou desencadeia o processo de precipitação do cálcio nas moléculas dos derivados pécticos presentes na lamela média, resultando no rompimento das forças de união e no afrouxamento das células armazenadoras de amido como um todo, permitindo que deslizem ou rolem umas sobre as outras, ao se comprimir ou amassar a polpa com o garfo ou ao mastigá-la.

Vilpoux \& Cereda (2003) sugeriram duas hipóteses para explicar o não cozimento da mandioca. A primeira é que a impermeabilização da parede celular impede a penetração da água nas células da raiz impedindo a gelificação do amido. Essa impermeabilização é um processo rápido o suficiente para explicar a diferença de cozimento entre mandiocas do mesmo campo, colhidas juntas e processadas com algumas horas de intervalo. A segunda hipótese admite alterações na parede celular, que não se deforma, impedindo o inchamento dos grânulos de amido e conseqüentemente de uma boa gelificação, fator característico do bom cozimento.

$\mathrm{O}$ cozimento industrial da mandioca pode ser classificado em 3 tipos. O tipo A em que o cozimento é normal e tem duração de até 30 minutos a temperatura de fervura da água e em pressão ambiente. $\mathrm{O}$ tipo $\mathrm{B}$, nas condições de cozimento e em pressão normal, a consistência é vítrea ou cerosa e a raiz abre-se em lamelas apresentando-se translúcida, sem sabor e sem aroma. Sob pressão o cozimento se desenvolve normalmente ou próximo da normalidade. $\mathrm{O}$ tipo $\mathrm{C}$ o cozimento não se desenvolve, mesmo sob condições de cozimento com pressão (Vilpoux \& Cereda, 2002). 
De acordo com Favaro (2003) os fatores responsáveis por diferenças nas características de cozimento da mandioca não estão suficientemente esclarecidos. Esse autor constatou diferença de tempo de cocção entre variedades e idades de colheita em uma mesma variedade, sendo de mais rápido cozimento as raízes de menor idade. Foi encontrada, uma menor quantidade de cálcio e magnésio e maior quantidade de potássio em raízes de mandioca da variedade Pioneira, de cocção mais rápida, em relação às raízes das variedades Taquari e Branca de Santa Catarina. Essa relação também foi observada quanto à idade dentro da mesma variedade, sendo que raízes de plantas com 7 meses apresentaram menores teores de cálcio e magnésio e maior teor de potássio em relação às raízes com 12 meses. Outra relação observada foi uma maior quantidade de polissacarídeos pécticos na variedade de maior tempo de cozimento.

\subsection{Características de massa cozida de tuberosas}

De modo geral, a massa de mandioca cozida preferida é aquela que se apresenta não encaroçada, plástica e não pegajosa. Esse tipo de massa irá atender a grande maioria dos procedimentos industriais que utilizam a mandioca cozida (Pereira et al., 1985). As características de textura, plasticidade e pegajosidade da massa cozida de mandioca estão associadas à duração do tempo de cozimento, sendo que quanto menor esse tempo, melhor a massa gerada (Lorenzi, 1994).

Farinosidade é uma característica de textura e refere-se a percepção na boca do alimento cozido. A farinosidade na mandioca é definida como a propriedade do tubérculo de desintegrar-se espontaneamente durante a cocção e esmigalhar-se em pedaços na aplicação de uma força cortante. A principal hipótese para explicar a farinosidade da mandioca é a da separação celular, baseada no fato de que a perda de substâncias pécticas intercelulares pode conduzir à liberação das células, o que confere a característica de cozido nos vegetais que passaram pelo processo de cocção (SafoKantanka \& Owusu-Nipah, 1992). Entretanto, Favaro (2003) não considera adequado o termo mealy ou farinácea para descrever a mandioca cozida, pois as características 
desejáveis pelo consumidor não correspondem àquelas que determinam o mealiness em batata. De acordo com esse autor o padrão preferido de mandioca cozida no norte do Paraná é aquele que promove sensação degustativa de um produto macio, úmido, liso e não farináceo. Esse autor ainda evidencia a importância da padronização dos termos a serem empregados para descrever as características de textura em mandioca.

No caso de batatas, a separação celular é o principal atributo físico do produto farináceo e o grau desse atributo é uma medida do grau de farinosidade. Certas características dos materiais pécticos disputam funções no desenvolvimento da qualidade de textura. $\mathrm{O}$ efeito destes materiais é oposto ao efeito do amido. $\mathrm{O}$ amido tende a causar o arredondamento e separação celular e os materiais pécticos tendem a equilibrar a força de adesividade para prevenir a separação celular (Sterling \& Battelheim, 1955). Potter \& McComb (1957) afirmam que a diferença entre batatas com diferentes farinosidades é devida a diferenças quantitativas e qualitativas das substâncias pécticas encontradas na parede celular e em materiais intercelulares na lamela média.

A qualidade da massa cozida de raízes tuberosas e de tubérculos pode ser influenciada por alguns parâmetros. Kawano \& Fukuda (1987) constataram que quanto maior o teor de matéria seca, maior a capacidade de cocção da mandioca. No caso de batatas, Jaswal (1989) observou que a qualidade culinária e a textura global são influenciadas pelo conteúdo de matéria seca e de amido, tamanho das células e dos grânulos de amido, teor de substâncias pécticas e de polissacarídeos não amiláceos.

A relação positiva entre o total de pectinato de cálcio e a textura firme pode ser explicada pelas propriedades coloidais das substâncias pécticas. Geralmente, materiais pécticos tendem produzir a ampliação da lamela média e aumentar a separação celular. Entretanto, essa tendência pode ser inibida pelas ligações catiônicas entre as moléculas de pectina, fortalecendo as ligações pécticas e impedindo a expansão da lamela média (Sterling \& Battelheim, 1955).

A farinosidade e a firmeza de batatas também se correlacionam com elevados teores de matéria seca (Krokida et al., 2001), gravidade específica, conteúdo de amido e tamanho de seus grânulos (Krokida et al., 2001; Briant et al., 1945; Bu-Contreras \& Rao, 2002). Battelheim \& Sterling (1955) afirmam que o teor de amido dos tubérculos é o 
principal fator determinante da textura da batata por causar o rompimento da parede celular durante a gelatinização do amido, resultando no arredondamento e separação das células. Warren \& Woodman (1974) concluíram que a farinosidade é dependente primariamente do teor de amido ou de sólidos do tubérculo e, em menor extensão, da coesividade celular em batatas. Krokida et al. (2001) também citam a espessura celular, os polissacarídeos da parede celular, os polissacarídeos não amiláceos e as substâncias pécticas como fatores controladores de textura de batatas. 


\section{MATERIAL E MÉTODOS}

\subsection{Material}

O cultivar IAC 576-70 foi selecionado para este estudo pela grande importância que apresenta para o Estado de São Paulo, constituindo a quase totalidade da área plantada para o consumo de mesa. Segundo Lorenzi \& Dias (1993) essa variedade apresenta como principais características morfológicas da raiz a presença de película suberosa rugosa e escura e tanto a feloderme como a polpa são de cor creme.

As plantas foram cultivadas no município de Piracicaba - SP e colhidas aos 12 e aos 15 meses de idade, respectivamente nos meses de fevereiro e maio de 2003. As amostras foram colhidas no período da tarde, armazenadas sob condições ambientais, no Laboratório de Amido e Produtos Amiláceos, da Escola Superior de Agricultura Luiz de Queiroz, Universidade de São Paulo, onde foram avaliadas na manhã do dia posterior.

Para cada época de colheita foram colhidas, ao acaso, 24 plantas de uma área homogênea. De cada planta foram utilizadas apenas cinco raízes de tamanho mais representativo do cultivar, que é o tamanho médio, ou seja, comprimento entre 25 e 30 centímetros. Para cada idade foram efetuadas 2 repetições, com sessenta raízes cada.

\subsection{Métodos}




\subsubsection{Preparo do material a ser analisado}

A seqüência das etapas de preparo do material para análises dentro de cada tratamento pode ser visualizada pela Figura 5.

\section{Raízes selecionadas}

(60 raízes)

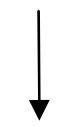

Retirada de 3 toletes centrais (aproximadamente $5 \mathrm{~cm}$ cada) de cada raiz

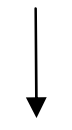

Teste prévio de tempo de cocção com $1 / 4$ de um dos 3 toletes provenientes de cada raiz

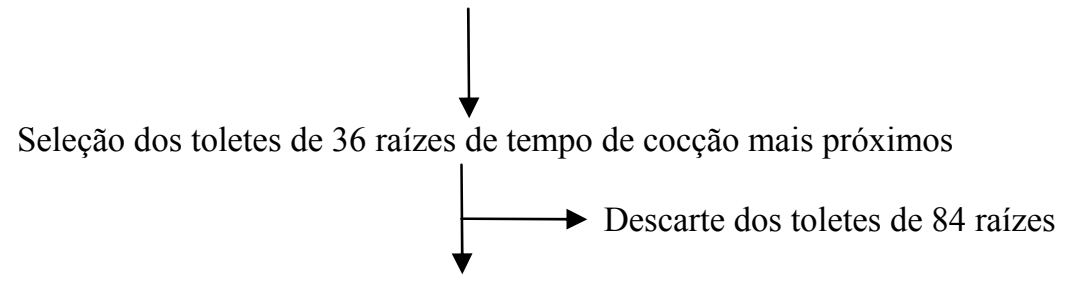

Descascamento e lavagem dos toletes das raízes selecionadas

\begin{tabular}{|c|c|c|c|}
\hline \multicolumn{4}{|c|}{ Divisão dos toletes das raízes selecionadas em lotes para tratamentos e análises diversas } \\
\hline$\downarrow$ & $\downarrow$ & $\downarrow$ & $\downarrow$ \\
\hline Raízes in natura & Raízes cozidas & Congelamento das raízes & Extração de amido \\
\hline $\begin{array}{l}\text { - Testes histoquímicos } \\
\text { - Textura (cisalhamento) }\end{array}$ & $\begin{array}{l}\text { - Adesão celular } \\
\text { - Testes histoquímicos }\end{array}$ & & Extração do amido \\
\hline $\begin{array}{l}\text { Raízes desidratadas e } \\
\text { moídas: } \\
\text { - Composição química } \\
\text { - Propriedades de pasta }\end{array}$ & $\begin{array}{l}\text { - Textura (cisalhamento) } \\
\text { Raízes cozidas, } \\
\text { desidratadas e moídas: } \\
\text { - Propriedades da pasta }\end{array}$ & $\begin{array}{l}\text { Descongelamento e } \\
\text { cozimento das raízes: } \\
\text { - Análise sensorial } \\
\text { - Textura: } \\
\text { - dureza } \\
\text { - adesividade } \\
\text { - cisalhamento }\end{array}$ & $\begin{array}{l}\text { Amido isolado: } \\
\text { - Amilose } \\
\text { - Tamanho dos grânulos } \\
\text { - Propriedades da pasta }\end{array}$ \\
\hline Tempo de cocção & & & \\
\hline
\end{tabular}

Figura 5 - Esquema de análises utilizado no experimento

Considerando que as raízes apresentam grande variabilidade quanto às características de cocção, foi tomada uma série de medidas para garantir maior 
homogeneidade e representatividade das amostras e poder relacionar o tempo de cocção com os demais parâmetros. De cada raiz foram retirados três toletes centrais medindo aproximadamente cinco centímetros cada e pesando entre 60 e 70 gramas. O primeiro tolete foi dividido em quatro partes e uma delas foi utilizada para um teste prévio quanto ao tempo de cocção. Foi avaliado o tempo em que a agulha penetrou o pedaço de tolete correspondente a cada raiz amostrada. Considerando os tempos de cocção apresentados pelas raízes foram selecionadas dezoito delas com os tempos mais próximos e de maior freqüência dentro de cada repetição. Apenas os toletes das raízes selecionadas foram utilizados para as análises subseqüentes. O material restante do primeiro tolete utilizado para o teste prévio de cocção, de cada raiz selecionada, foi destinado à extração de amido.

Os demais toletes das 18 raízes selecionadas de cada repetição, totalizando 36 toletes, foram descascados e lavados. Esse material foi separado em três partes.

A primeira parte do material foi submetida à determinação do tempo ideal de cocção. No material resultante do processo de cocção foram realizadas análises de resistência ao cisalhamento em texturômetro e testes histoquímicos. Parte do material cozido pelo tempo ideal de cocção também foi desidratada em estufa com circulação de ar a $35^{\circ} \mathrm{C}$, moída e peneirada em peneira de malha 60 mesh. Este material foi avaliado quanto às propriedades de pasta (viscosidade).

Uma outra parte do material in natura foi destinada a testes histoquímicos, análise de textura quanto à resistência ao cisalhamento e parte do material foi fatiado. Deste material fatiado foi retirada amostra para a determinação do teor de matéria seca, sendo o restante desidratado em estufa com circulação de ar a $35^{\circ} \mathrm{C}$, até umidade inferior a $14 \%$, e moído. Neste material desidratado (farinha de raspas) foram realizadas análises para determinação da composição das raízes.

Uma outra parte do material (toletes) ainda foi congelada e armazenada em freezer a $-18^{\circ} \mathrm{C}$ para análises posteriores de textura e sensorial das raízes cozidas. 


\subsubsection{Composição da raiz in natura}

A composição das raízes cruas que passaram por processo de desidratação foi avaliada por análises realizadas em triplicata. Foram avaliados os teores de matéria seca, amido, carboidratos redutores, pectina, fibras (solúvel, insolúvel e total), lipídeos, cinzas e minerais (cálcio, magnésio e potássio).

\subsubsection{Teor de umidade}

Para a determinação do teor de umidade foram pesados $3 \mathrm{~g}$ de amostra em placas de Petri previamente taradas e colocados em estufa com circulação de ar a $105^{\circ} \mathrm{C}$ até peso constante (AOAC, 1995).

\subsubsection{Teor de amido}

A determinação do teor de amido foi realizada segundo o método enzimático descrito em Rickard \& Behn (1987) e a dosagem dos açúcares redutores por SomogyNelson (Somogy, 1945).

\subsubsection{Teor de carboidratos redutores}

A determinação do teor de carboidratos redutores foi realizada segundo o método de Somogy-Nelson (Somogy, 1945). 


\subsubsection{Teor de lipídeos}

O teor de lipídeos das amostras foi avaliado em aparelho Soxleth tendo como solvente o hexano, conforme técnica da AOAC (1995).

\subsubsection{Teor de proteínas}

O teor de nitrogênio das amostras foi determinado pelo método microKjeldahl segundo metodologia da AOAC (1995). O fator 6,25 foi empregado para a conversão do nitrogênio detectado em proteína bruta.

\subsubsection{Teor de cinzas}

O teor de cinzas foi determinado após incineração da amostra em mufla a $550^{\circ} \mathrm{C}$ segundo o método descrito pela AOAC (1995).

\subsubsection{Teor de fibras}

Os teores de fibras solúveis e insolúveis foram determinados pelo método enzimático de Asp et al. (1983). E pela somatória desses teores determinou-se o teor de fibras totais.

\subsubsection{Teor de pectina}

O teor de pectina solúvel e total foi determinado pelo método do mhidroxidifenil de acordo com McCready \& McComb (1952). O resultado foi expresso em mg de ácido galacturônico por $100 \mathrm{~g}$ de amostra. 


\subsubsection{Teor de minerais}

Os minerais foram determinados após digestão nitroperclórica do material segundo recomendação de Sarruge \& Haag (1974). Os cátions divalentes, cálcio e magnésio foram determinados através de espectrofotometria de absorção atômica em aparelho Perkin Elmer, modelo 3.110. O teor de potássio foi quantificado neste mesmo material, por fotometria de chama.

\subsubsection{Tempo de cocção das raízes}

Essa avaliação foi realizada nos testes prévios em quartos de toletes de cada raiz e posteriormente em toletes inteiros, com pesos de 60 a $70 \mathrm{~g}$, para determinar o tempo ideal de cocção. Para essas determinações foi utilizado o aparelho Mattson com adaptações do modelo apresentado por Miranda (2000), conforme Figura 6. Cada agulha fixada em haste de vidro apresentava peso total de 90,0g. Procedeu-se a imersão do aparelho com as amostras em recipiente de aço inoxidável contendo água destilada em ebulição. A quantidade de água foi a suficiente para manter o material submerso durante todo o tempo de cocção.

Nos testes prévios foi considerado o tempo em que todas as agulhas penetraram as raízes amostradas. Na determinação do tempo ideal de cocção foram utilizados 12 toletes de mandioca e sobre cada um deles, a ponta de uma das agulhas, sendo considerado tempo ideal de cozimento aquele em que a sétima agulha (metade mais uma) descia $2 \mathrm{~cm}$ para dentro da amostra. 


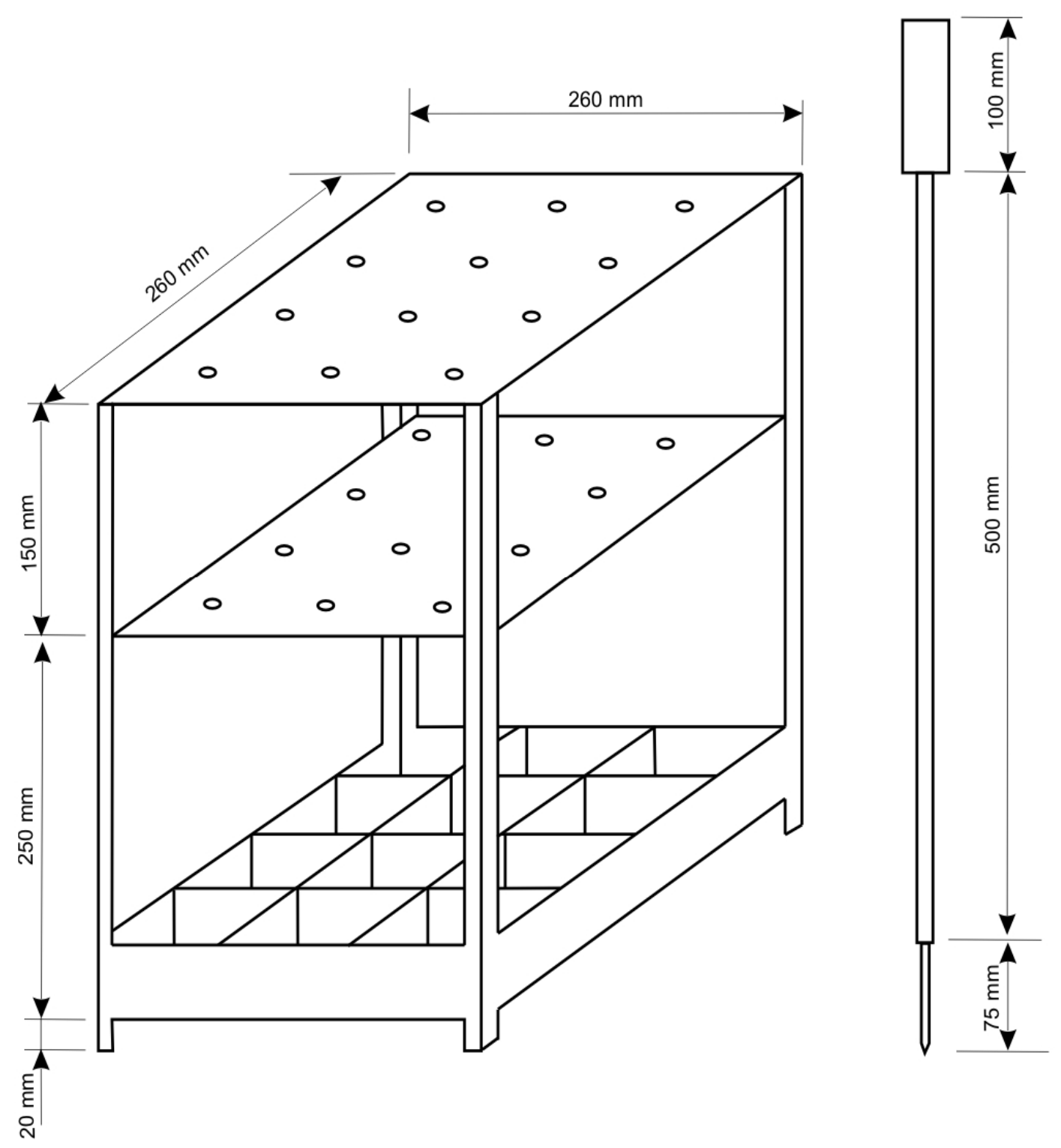

Figura 6 - Aspecto do aparelho Mattson, modificado, utilizado para avaliar tempo de cocção das raízes de mandioca 


\subsubsection{Adesão celular}

A adesão celular do tecido vegetal foi avaliada de acordo com Eggleston \& Asiedu (1994). Essa análise determina a desintegração celular calculada pela perda de massa seca do material cozido após agitação. Essa avaliação foi realizada em triplicata.

Primeiramente foi determinada a matéria seca de uma porção de $50 \mathrm{~g}$ de amostra. Dessa porção, foram também pesadas $15 \mathrm{~g}$ de amostra em béquer e adicionados $60 \mathrm{~mL}$ de água destilada. O béquer foi colocado para agitar por 15 minutos em banho de água tipo Dubnoff, marca Marconi, modelo MA093, em temperatura ambiente. Ao término da agitação, as amostras foram drenadas em papel de filtro qualitativo e o teor de matéria seca foi novamente determinado. A porcentagem de perda de massa seca é relatada como porcentagem de desintegração.

\subsubsection{Avaliação histoquímica das raízes}

Os testes histoquímicos foram realizados tanto em raízes cruas como cozidas pelo tempo ideal de cocção, ou seja, aquele tempo determinado para as raízes das plantas daquele determinado tratamento (idade ou repetição).

A avaliação histoquímica foi efetuada em cortes muito finos do material, feitos à mão livre, utilizando-se lâminas. O corante Vermelho de Rutênio foi utilizado para a observação de compostos pécticos e o corante Sudan IV para evidenciar a presença de substâncias lipídicas (Jensen, 1962). Já o corante cloreto férrico a 10\% acrescido de carbonato de sódio foi utilizado para detectar a presença de compostos fenólicos e a floroglucina acrescida de ácido clorídrico concentrado para detectar paredes lignificadas (Johansen, 1940). O registro dos resultados foi efetuado através de fotomicrografias feitas em fotomicroscópio Zeiss (MC-80), sendo que o aumento final foi registrado nas condições ópticas adequadas, de acordo com o aparelho utilizado. 


\subsubsection{Textura das raízes quanto à resistência ao cisalhamento}

Estas avaliações foram efetuadas nas raízes cruas e cozidas pelo tempo considerado como ideal para a cocção das raízes de plantas em cada idade estudada.

As avaliações foram realizadas em seis toletes, com peso de 60 a 70 gramas cada, segundo Di-Tanno (2001), em texturômetro Texture Test System, Série 2053, Modelo TP1, acoplado a um registrador automático de variação de força, operando em célula padrão de compressão de cisalhamento CS-1, com 10 lâminas de 1/8 polegadas de espessura e ângulo de $90^{\circ}$. O instrumento operou com os sensores eletrônicos de 300 libras-força (lbf) para o material cru e 1000 libras-força para o material cozido. A velocidade de descida do pistão foi de $20 \mathrm{~cm} / \mathrm{min}$.

As medidas de resistência ao cisalhamento foram obtidas através da força

máxima de cisalhamento detectada no registrador, multiplicada pelo fator de posição do sensor eletrônico (3 se sensor em 300 lbf e 10 se sensor em 1000 lbf) e dividida pelo peso da amostra, sendo expressas em lbf/g de amostra.

\subsubsection{Avaliação das raízes congeladas}

\subsubsection{Descongelamento das raízes}

O material congelado foi descongelado diretamente em água fervente, por imersão, nos tempos considerados ideais para cocção das raízes daquele tratamento, ou seja, 16 e 21 minutos, respectivamente para as raízes de plantas com 12 e 15 meses de idade. 


\subsubsection{Textura das raízes}

As raízes descongeladas e cozidas foram avaliadas quanto à resistência ao cisalhamento de acordo com o item.3.2.6.

As amostras cozidas foram também submetidas à avaliação do grau de dureza (resistência à força) e a adesividade (aderência). Para isto, os toletes descongelados e cozidos foram cortados transversalmente, em formato cilíndrico, com $20 \mathrm{~mm}$ de diâmetro e $30 \mathrm{~mm}$ de altura. Foram realizadas 12 replicatas. Esta análise de textura instrumental foi realizada no analisador de textura TA-XT2i, utilizando o probe P-36R (cilíndrico) e plataforma HDP/ 90, operando nas seguintes condições:

- medida de força de compressão;

- velocidade de pré-teste: $1,0 \mathrm{~mm} / \mathrm{s}$;

- velocidade de teste: $1,0 \mathrm{~mm} / \mathrm{s}$;

- velocidade de pós-teste: $1,0 \mathrm{~mm} / \mathrm{s}$;

- distância: $15 \mathrm{~mm}$.

Os resultados foram expressos em grama-força $(g)$.

\subsubsection{Análise sensorial das raízes}

O método utilizado na análise sensorial foi o de aceitabilidade, por Escala Hedônica, segundo Poste et al. (1991).

Para esta análise foram utilizados 30 provadores não treinados, de ambos os sexos e com idade entre 20 e 40 anos. As amostras, sob a forma de toletes, foram cozidas de acordo com o tempo ideal de cada tratamento e fatiadas longitudinalmente em quatro partes. Foram servidas em cabines individuais no período vespertino (14:00 15:30 h) em um único dia. Foi utilizada uma escala hedônica de 9 pontos variando de gostei extremamente a desgostei extremamente. As notas foram atribuídas posteriormente para o cálculo da média dos provadores. O modelo de ficha preenchida pelos provadores pode ser visualizado na Figura 7. 


\section{TESTE DE ACEITABILIDADE}

Nome:

Data:

Por favor avalie as amostras de mandioca cozida utilizando a escala abaixo para descrever o quanto você gostou ou degostou. Indique na escala o código de cada amostra que melhor corresponde ao seu julgamento. Em seguida responda as questões abaixo. Obrigado.

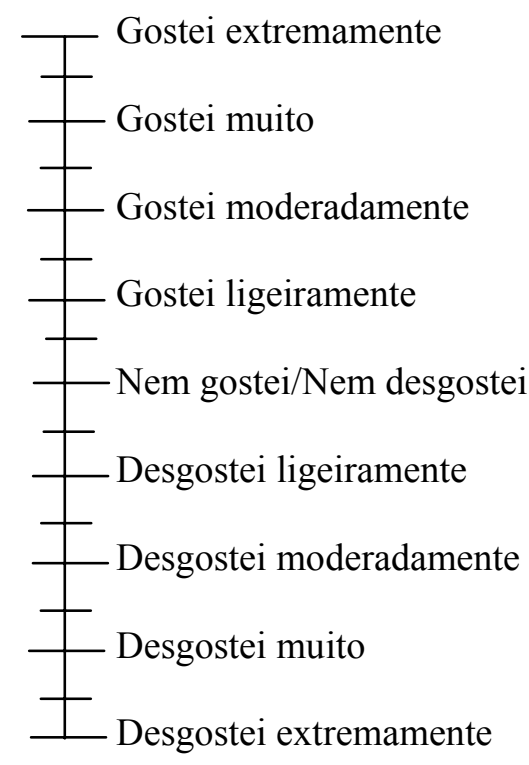

Porque gostei:

429

537

Porque desgostei:

429

537

Freqüência de consumo: ( ) 1 a 2 vezes por semana ( ) a cada 15 dias ( ) 1 vez por mês

Outras formas de consumo: ( ) frita ( ) purê ( ) sopa ( ) croquetes

Figura 7 - Modelo da ficha utilizada na análise sensorial das raízes cozidas de mandioca 


\subsubsection{Extração e caracterização do amido}

\subsubsection{Extração do amido}

A extração do amido das raízes de mandioca foi realizada segundo o método descrito por Sarmento (1997). O amido assim extraído foi avaliado quanto ao teor de amilose, tamanho dos grânulos e propriedades da pasta.

\subsubsection{Teor de amilose aparente}

O teor de amilose aparente no amido foi determinado segundo o método descrito pela ISO 6647 (International Organization for Standardization, 1987), em triplicata.

\subsubsection{Tamanho dos grânulos}

O tamanho dos grânulos de amido foi avaliado pelo Sistema de Análise de Imagem KS 300 da Zeiss. As amostras de amido foram coletadas com fio de platina e misturadas, sobre lâminas de vidro, com duas gotas de água destilada e, posteriormente, cobertas com lamínula. As lâminas foram observadas em microscópio óptico Zeiss (MC80) e as imagens selecionadas foram analisadas pelo sistema. Essa determinação foi realizada em duplicata.

Em função da irregularidade nos formatos dos grânulos, o software foi direcionado para tomar medidas quanto ao diâmetro maior, diâmetro menor e área superficial aparente. Foram efetuadas 600 medidas de grânulos de cada amostra. Os resultados foram reportados também em histogramas como distribuição de freqüência para o conjunto de dados quantitativos. 


\subsubsection{Propriedades da pasta}

As propriedades de pasta dos amidos isolados das raízes in natura foram avaliadas em aparelho Rapid Visco Analyser (RVA), série 4, da Newport Scientific, na concentração de 2,5g/25 mL de água. Para o cálculo desta concentração foram efetuadas correções na quantidade de amido a ser pesada e na quantidade de água a ser adicionada, segundo tabela fornecida pelo fabricante (Newport Scientific, 1998), tomando como base um teor de umidade de $14 \%$, para se obter um peso seco de amido de 2,5g.

As raízes cozidas, desidratadas e moídas foram também avaliadas pelo Rapid Visco Analyser, utilizando-se a concentração de $3,5 \mathrm{~g} / 25 \mathrm{~mL}$ de água, também corrigidos para a base de $14 \%$ de umidade.

Foi utilizada a programação Std 2 (Standard Analysis 2) do software Thermocline for Windows, versão 2.2, procedendo a seguinte programação tempo/temperatura: $50^{\circ} \mathrm{C}$ por 1 minuto, aquecimento de 50 a $95^{\circ} \mathrm{C}$ a uma taxa de $6^{\circ} \mathrm{C} /$ min, manutenção da pasta a $95^{\circ} \mathrm{C}$ por 5 minutos e resfriamento de 95 a $50^{\circ} \mathrm{C}$ a uma taxa de $6^{\circ} \mathrm{C} /$ minuto.

Do gráfico obtido foram avaliadas as seguintes características: temperatura de pasta, viscosidade máxima (pico), quebra de viscosidade (diferença entre a viscosidade máxima e da pasta mantida a $95^{\circ} \mathrm{C}$ por 5 min.), viscosidade final e tendência à retrogradação (diferença entre as viscosidades final e da pasta a $50^{\circ} \mathrm{C}$ por $5 \mathrm{~min}$.). Esses parâmetros podem ser melhor visualizados pelo gráfico apresentado na Figura 8 .

Nas análises dos resultados obtidos para temperatura de pasta por esse programa foi feita correção na fórmula, de TempAtViscRate $(1 ; 13 ; 1 ; 24)$ para TempAtViscRate $(1 ; 13 ; 1 ; 6)$. As unidades de viscosidade geradas pelo equipamento são arbitrárias, em RVU, ou seja, Rapid Visco Units. Essas determinações foram realizadas em duplicatas. 


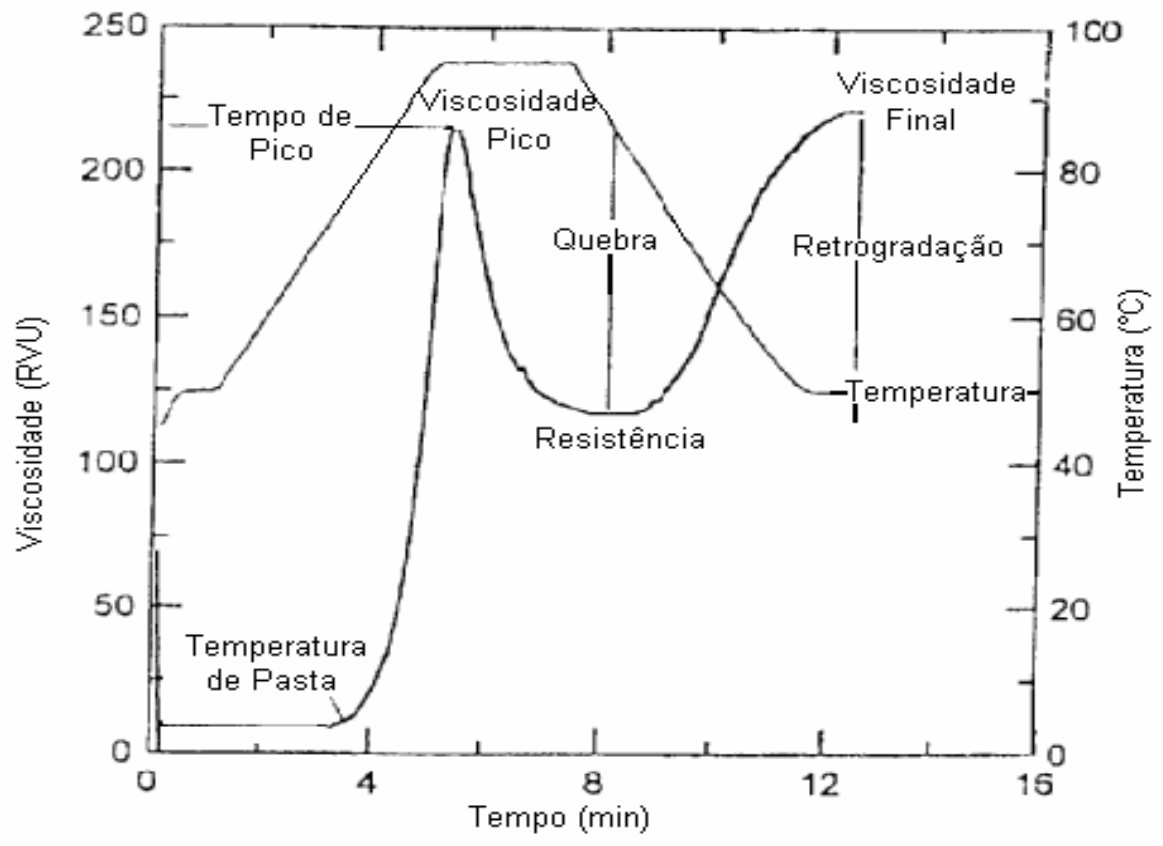

Figura 8 - Curva típica do Rapid Visco Analyser (RVA)

Fonte: Thomas \& Atwell (1999)

\subsubsection{Análise estatística}

O delineamento experimental utilizado foi o inteiramente ao acaso, com 2 repetições para cada idade de planta estudada (12 e 15 meses).

Para avaliar as tendências comportamentais dos dados foram utilizadas medidas de posição, que permitem verificar a distribuição e o comportamento de dados quantitativos no intervalo fechado, e medidas de dispersão, que medem as variabilidades dos dados em estudo e verificar se o conjunto de dados é homogêneo ou heterogêneo. A análise estatística foi realizada através do software Minitab Release 13.1 (Minitab, 2003) abrangendo a análise descritiva dos dados e comparação de médias pela análise de variância (ANOVA) utilizando-se o teste de Tukey. 


\section{RESULTADOS E DISCUSSÃO}

As condições climáticas durante o desenvolvimento da cultura e no período da colheita podem afetar a qualidade das raízes de mandioca. A influência desses fatores decorre dos processos fisiológicos de crescimento, acúmulo e mobilização de substâncias nas raízes tuberosas dessa planta, que irão interferir na composição das raízes e qualidade da massa cozida (Lorenzi, 1994). De acordo com Vilpoux \& Cereda (2003) mandioca apresenta melhor cozimento quando entra em repouso fisiológico e quando passa por período de estresse (seca ou frio).

As temperaturas médias e as pluviosidades mensais no município de Piracicaba, onde as plantas foram cultivadas, são apresentadas na Tabela 1 .

As plantas de 12 e 15 meses foram colhidas em fevereiro e maio de 2003, respectivamente. No Estado de São Paulo esses meses correspondem a fases diferentes do ciclo desse vegetal. No mês de fevereiro as plantas estavam no período de desenvolvimento vegetativo e em maio, no início do período de repouso físiológico, ou seja, as plantas já se encontravam com poucas folhas.

No presente trabalho, além de se avaliar a idade das plantas, deve se considerar os diferentes momentos fisiológicos do vegetal nos períodos onde foram efetuadas essas colheitas. Para referência aos tratamentos utilizados neste estudo serão utilizados os termos para idade (12 e 15 meses), muito embora na discussão, os períodos (vegetativo e repouso) não deixam de serem considerados. 
Tabela 1. Temperaturas médias e pluviosidades mensais na região de Piracicaba - SP durante o desenvolvimento da cultura no campo

\begin{tabular}{lcc}
\hline Meses & $\begin{array}{c}\text { Temperatura média } \\
\text { Mensal }\left({ }^{\circ} \mathrm{C}\right)\end{array}$ & $\begin{array}{c}\text { Pluviosidade mensal } \\
(\mathrm{mm})\end{array}$ \\
\hline 2002 & 23,9 & 187,9 \\
Fevereiro (plantio) & 25,8 & 274,6 \\
Março & 24,7 & 27,2 \\
Abril & 20,7 & 112,4 \\
Maio & 20,3 & 0,0 \\
Junho & 17,7 & 23,4 \\
Julho & 21,6 & 79,6 \\
Agosto & 20,6 & 44,8 \\
Setembro & 26,3 & 49,4 \\
Outubro & 24,7 & 176,5 \\
Novembro & 25,4 & 166,1 \\
Dezembro & & \\
2003 & 24,9 & 302,4 \\
Janeiro & 26,5 & 58,6 \\
Fevereiro (1 ${ }^{\mathrm{a}}$ colheita) & 24,3 & 180,9 \\
Março & 22,6 & 55,2 \\
Abril & 18,8 & 54,7 \\
Maio (2a colheita) & &
\end{tabular}

Fonte: Posto Agrometeorológico da ESALQ (2004)

No presente trabalho, durante o período de crescimento das plantas de mandioca a temperatura média foi de $25,3^{\circ} \mathrm{C}$ para as plantas colhidas em fevereiro de 2003 e de $24,6^{\circ} \mathrm{C}$ para as plantas colhidas em maio de 2003. Essas temperaturas médias encontram-se dentro da faixa ideal apontada por Lorenzi \& Dias (1993), que se situa entre 23 e $25^{\circ} \mathrm{C}$, como adequada para um bom desenvolvimento da planta.

Em relação ao índice pluviométrico verificou-se regime hídrico com um total de precipitação pluviométrica de $1477,9 \mathrm{~mm}$ para as plantas colhidas aos 12 meses de idade e de $1768,7 \mathrm{~mm}$ para as plantas colhidas aos 15 meses de idade. De acordo com 
Lorenzi \& Dias (1993) a mandioca pode ser cultivada em regimes hídricos com precipitação pluviométrica variando de 600 a $4000 \mathrm{~mm}$, sendo o volume ideal de chuvas entre 1000 e $1500 \mathrm{~mm}$ bem distribuídas, especialmente nos seis primeiros meses após o plantio. No presente experimento foram observados índices mais baixos de pluviosidade durante os meses de abril e de junho a outubro de 2002, mais próximos ao que corresponde à estação seca na região de Piracicaba. No mês de junho de 2002, entretanto, faltou precipitação pluviométrica.

As condições de temperatura durante o desenvolvimento da cultura no campo apresentaram-se dentro dos requerimentos para esta cultura. Durante o inverno as temperaturas não foram demasiadamente baixas.

\subsection{Composição das raízes de mandioca}

O tempo de cocção e a qualidade de massa cozida de mandioca estão relacionados com a composição química das raízes (Safo-Kantanka \& Owusu-Nipah, 1992; Eggleston \& Asiedu, 1994).

As raízes de mandioca do cultivar IAC 576-70 apresentaram a composição química mostrada na Tabela 2.

Não foi observada variação significativa nos teores de matéria seca presentes nas raízes das plantas deste cultivar aos 12 meses e aos 15 meses, sendo de 33,1\% e $34,9 \%$, respectivamente. Esses valores encontram-se dentro de faixas de variação citadas na literatura, de 30 a 42\% (Sarmento, 1997; Pereira \& Beléia, 2004). Pequenas diferenças nos teores de umidade das raízes podem ser oriundas da variação da quantidade de água disponível no solo. Para plantas colhidas no início de fevereiro de 2003 a disponibilidade de água era mais elevada em decorrência da alta pluviosidade nos meses que antecederam este período, e para as plantas colhidas em maio de 2003 os totais pluviométricos dos meses anteriores foram baixos. 
Tabela 2. Composição centesimal das raízes de mandioca do cultivar IAC 576-70 aos 12 e aos 15 meses de idade

\begin{tabular}{lcc}
\hline \multirow{2}{*}{ Composição centesimal (\%) } & \multicolumn{2}{c}{ Média e desvio padrão } \\
\cline { 2 - 3 } & 12 meses & 15 meses \\
\hline Umidade & $66,86^{\mathrm{a}} \pm 1,953$ & $65,15^{\mathrm{a}} \pm 1,051$ \\
Amido & $26,63^{\mathrm{a}} \pm 1,437$ & $31,09^{\mathrm{b}} \pm 1,119$ \\
Carboidratos redutores & $2,45^{\mathrm{a}} \pm 0,232$ & $1,65^{\mathrm{b}} \pm 0,169$ \\
Fibras totais & $1,26^{\mathrm{a}} \pm 0,364$ & $1,99^{\mathrm{b}} \pm 0,380$ \\
$\quad$ & $0,74^{\mathrm{a}} \pm 0,326$ & $1,15^{\mathrm{a}} \pm 0,269$ \\
$\quad$ Fibras insolúveis & $0,51^{\mathrm{a}} \pm 0,250$ & $0,84^{\mathrm{a}} \pm 0,321$ \\
$\quad$ Fibras solúveis & $0,78^{\mathrm{a}} \pm 0,042$ & $0,78^{\mathrm{a}} \pm 0,022$ \\
Cinzas & $0,70^{\mathrm{a}} \pm 0,025$ & $0,69^{\mathrm{a}} \pm 0,019$ \\
Proteínas & $0,12^{\mathrm{a}} \pm 0,005$ & $0,12^{\mathrm{a}} \pm 0,007$ \\
Lipídeos & & \\
\hline
\end{tabular}

Nota: médias com letras diferentes na mesma linha diferem entre si em nível de 5\% de probabilidade pelo teste de Tukey

A composição química das raízes apresentou variação significativa durante o período estudado quanto aos teores de amido, de carboidratos redutores e de fibras totais.

A primeira colheita, aos 12 meses de idade, se deu no período vegetativo, quando a planta necessitava mais energia para completar seu primeiro ciclo de desenvolvimento. Isto implica em menor acúmulo de amido nas raízes e justifica o maior teor de carboidratos redutores presentes. Comportamento semelhante foi observado por outros autores, como Pereira \& Beléia (2004), que estudaram raízes de plantas de mandioca com 19 meses de idade, na fase vegetativa do segundo ciclo, e encontraram elevados teores $(8,8 \%)$ de carboidratos não amídicos nas mesmas. De acordo com esses autores as plantas obtiveram a energia necessária para esta fase fisiológica a partir do amido armazenado nas raízes, cujos metabolismos promoveram a 
produção de açúcares redutores. Já as plantas com 15 meses foram colhidas em maio, época em que perdem as folhas e entram na fase de repouso fisiológico, quando tendem a acumular maiores teores de amido nas raízes.

Sarmento (1997) estudando raízes de quatro cultivares de mandioca encontrou maiores teores de amido (32,3 a 36,3\%) em plantas aos 10 meses, durante o período de repouso e menores teores $(30,2$ a $34,8 \%)$ em plantas aos 14 meses, durante o período vegetativo.

Os teores de fibras solúveis e insolúveis encontram-se abaixo dos valores encontrados por Di-Tanno (2001) para raízes do cultivar Ouro do Vale aos 14 meses de idade, que foram de 3,5\% (fibras solúveis) e de 5,1\% (fibras insolúveis).

Embora os teores de fibras solúveis e insolúveis das raízes nas idades estudadas não tenham apresentado diferenças significativas, a somatória dos mesmos (fibras totais) acusou aumento significativo com a idade das plantas, provavelmente devido ao maior tempo de permanência das raízes no solo.

A maioria dos trabalhos da literatura afirma que o teor de fibras nas raízes de mandioca aumenta com a idade da planta. Kato et al. (1987) encontraram incremento dos teores de fibra bruta das raízes com o envelhecimento das plantas, como conseqüência, observaram modificação da textura e aumento do tempo de cocção das raízes. Pereira \& Beléia (2004) observaram decréscimo no teor de fibra bruta das raízes com o aumento da idade das plantas de mandioca, dos meses 7 aos 19 meses.

Os percentuais de cinzas ( $0,8 \%$ para ambas as idades) encontrados no presente estudo estão abaixo dos obtidos por Pereira \& Beléia (2004). Para as raízes de plantas com 7 e 19 meses de idade, estes autores encontraram os teores 2,3\% e 1,9\%, respectivamente, decrescente com a idade.

Os teores de proteínas e lipídeos presentes nas raízes de mandioca não apresentaram diferença estatística entre as idades de plantas. Sarmento (1997) avaliando cultivares de mandioca dos 10 aos 24 meses observou decréscimo no teor de proteína e não observou variação dos teores de lipídeos.

A composição química da massa seca das raízes de plantas aos 12 e 15 meses é apresentada na Tabela 3. 
Tabela 3. Componentes químicos da massa seca das raízes de mandioca do cultivar IAC 576-70 aos 12 e aos 15 meses de idade

\begin{tabular}{lcc}
\hline \multirow{2}{*}{ Composição da mass seca (\%) } & \multicolumn{2}{c}{ Média e desvio padrão } \\
\cline { 2 - 3 } & $12^{\text {meses }}$ & 15 meses \\
\hline Amido & $80,3^{\mathrm{a}} \pm 2,20$ & $88,5^{\mathrm{b}} \pm 2,99$ \\
Carboidratos redutores & $7,4^{\mathrm{a}} \pm 0,87$ & $4,7^{\mathrm{b}} \pm 0,52$ \\
Fibras totais & $3,8^{\mathrm{a}} \pm 1,03$ & $5,7^{\mathrm{b}} \pm 1,13$ \\
$\quad$ & $2,2^{\mathrm{a}} \pm 0,93$ & $3,3^{\mathrm{a}} \pm 0,78$ \\
$\quad$ Fibras insolúveis & $1,6^{\mathrm{a}} \pm 0,77$ & $2,4^{\mathrm{a}} \pm 0,94$ \\
$\quad$ Fibras solúveis & $2,4^{\mathrm{a}} \pm 0,18$ & $2,3^{\mathrm{a}} \pm 0,05$ \\
Cinzas & $2,1^{\mathrm{a}} \pm 0,03$ & $1,9^{\mathrm{b}} \pm 0,07$ \\
Proteínas & $0,4^{\mathrm{a}} \pm 0,01$ & $0,3^{\mathrm{b}} \pm 0,01$ \\
Lipídeos &
\end{tabular}

Nota: médias com letras diferentes na mesma linha diferem entre si em nível de 5\% de probabilidade pelo teste de Tukey

Através dos resultados, pode-se observar acréscimos significativos nos teores de amido e fibras totais com o aumento do período de colheita, acarretando reduções significativas principalmente nos teores de carboidratos redutores.

Em relação ao teor protéico e lipídico, no presente trabalho foi observado um pequeno decréscimo com o aumento da idade. Gómez et al. (1985) estudando a composição química das raízes de algumas variedades de mandioca com a idade das plantas observaram decréscimo do teor de proteínas. E em relação aos lipídeos, esse decréscimo também foi verificado por Pereira e Beléia (2004) na base seca.

Outros componentes químicos normalmente associados com textura dos vegetais de um modo geral são as pectinas e essas, podem apresentar associações com os minerais. De acordo com Bruce et al. (1997) essas associações são especialmente abundantes na lamela média e são ligações cruzadas que se estabelecem entre as pectinas 
e os íons bivalentes. Tais ligações auxiliam a manter os componentes da parede celular unidos.

A Tabela 4 mostra os teores de pectinas e de minerais apresentados pelas raízes de plantas de mandioca com 12 e 15 meses de idade e a Tabela 5 apresenta esses mesmos componentes na massa seca das raízes.

Tabela 4. Teores de pectinas e de minerais em raízes de mandioca do cultivar IAC 57670 , aos 12 e aos 15 meses de idade

\begin{tabular}{lcc}
\hline \multirow{2}{*}{ Componentes } & \multicolumn{2}{c}{ Média e desvio padrão } \\
\cline { 2 - 3 } & 12 meses & 15 meses \\
\hline Pectina solúvel (mg ác. galacturônico/100g) & $88,3^{\mathrm{a}} \pm 13,71$ & $76,0^{\mathrm{a}} \pm 10,42$ \\
Pectina total (mg ác. galacturônico/100g) & $245,8^{\mathrm{a}} \pm 12,24$ & $219,5^{\mathrm{a}} \pm 31,67$ \\
Cálcio (\%) & $0,038^{\mathrm{a}} \pm 0,004$ & $0,038^{\mathrm{a}} \pm 0,009$ \\
Magnésio (\%) & $0,045^{\mathrm{a}} \pm 0,001$ & $0,046^{\mathrm{a}} \pm 0,000$ \\
Potássio (\%) & $0,936^{\mathrm{a}} \pm 0,126$ & $0,892^{\mathrm{a}} \pm 0,039$ \\
\hline
\end{tabular}

Nota: médias com letras diferentes na mesma linha diferem entre si em nível de 5\% de probabilidade pelo teste de Tukey

Dentre os microcomponentes estudados nas raízes deste cultivar, apenas o teor de pectina total apresentou diferença significativa entre plantas com 12 e 15 meses, sendo mais elevado nas plantas mais novas.

Favaro (2003) isolou o material da parede celular de raízes de mandioca das variedades Pioneira e Branca de Santa Catarina. No material isolado foram encontrados $44 \%$ de pectinas para raízes da variedade Pioneira e 32\% de pectinas para raízes da variedade Branca de Santa Catarina. 
Tabela 5. Teores de pectinas e de minerais na matéria seca de raízes de mandioca, cultivar IAC 576-70, aos 12 e aos 15 meses de idade

\begin{tabular}{lcc}
\hline \multirow{2}{*}{ Componentes } & \multicolumn{2}{c}{ Média e desvio padrão } \\
\cline { 2 - 3 } & 12 meses & 15 meses \\
\hline Pectina solúvel (mg ác. galacturônico/100g) & $267,5^{\mathrm{a}} \pm 48,3$ & $218,4^{\mathrm{a}} \pm 31,3$ \\
Pectina total (mg ác. galacturônico/100g) & $742,5^{\mathrm{a}} \pm 45,8$ & $630,1^{\mathrm{b}} \pm 92,2$ \\
Cálcio (mg/100g) & $39,6^{\mathrm{a}} \pm 4,59$ & $38,5^{\mathrm{a}} \pm 9,08$ \\
Magnésio (mg/100g) & $45,5^{\mathrm{a}} \pm 0,55$ & $46,0^{\mathrm{a}} \pm 0,0$ \\
Potássio (mg/100g) & $935,7^{\mathrm{a}} \pm 126,43$ & $892,3^{\mathrm{a}} \pm 39,24$ \\
\hline
\end{tabular}

Nota: médias com letras diferentes na mesma linha diferem entre si em nível de 5\% de probabilidade pelo teste de Tukey

Favaro (2003) determinou teores de minerais em raízes de mandioca da variedade Pioneira aos 12 meses de idade, que foram de 81,5mg/100g de cálcio, $56,0 \mathrm{mg} / 100 \mathrm{~g}$ de magnésio e $1010,0 \mathrm{mg} / 100 \mathrm{~g}$ de potássio na massa seca. Os teores de magnésio e potássio encontrados no presente estudo estão próximos e o de cálcio estão abaixo desses valores obtidos por Favaro (2003).

De acordo com Oke (1968) os teores de cálcio (13mg/100g), de magnésio $(4 \mathrm{mg} / 100 \mathrm{~g})$ e de potássio $(138 \mathrm{mg} / 100 \mathrm{~g})$ na massa seca de raízes de mandioca são inferiores aos teores encontrados para esses minerais no presente experimento.

\subsection{Características do amido}

Durante a cocção o amido gelifica e promove o arredondamento celular, o que provoca o rompimento da lamela média, influenciando as características da massa apresentada após cocção (Battelheim \& Sterling, 1955; Warren \& Woodman 1974). Por inferência, as características que alteram a gelificação deste polímero podem também 
afetar a cocção das raízes. Se não houver entrada de água nas células ou se a parede celular estiver rígida, não se consegue gelificação do amido.

O amido extraído das raízes de mandioca das plantas com 12 e 15 meses de idade foi avaliado no presente experimento quanto ao teor de amilose, tamanho dos grânulos e propriedades da pasta.

\subsubsection{Teor de amilose aparente}

O teor de amilose no amido de plantas aos 12 meses foram de 19,6\% $\pm 0,29$ e aos 15 meses de 18,7\% $\pm 0,68$, não ocorrendo variação estatisticamente significativa nestes teores entre as idades ou períodos estudados.

Segundo Rickard et al. (1991) o teor de amilose em amido de mandioca pode variar entre 13,6 e 23,8\%. Os valores encontrados neste estudo foram ligeiramente superiores aos citados por Sarmento (1997) para a variedade Branca de Santa Catarina, que foram de $18,16 \%$ e 18,03\%, respectivamente para raízes de plantas com 12 meses e 16 meses.

Relações entre teores de amilose e cocção podem ser encontradas na literatura para outros produtos amiláceos como arroz. De acordo com Ong \& Blanshard (1995) os grãos de arroz com maiores teores de amilose apresentam-se mais duros após a cocção. Entretanto esses autores atribuíram a dureza de arroz também às cadeias mais longas de amilopectina, que poderiam ter influência sobre a textura mesmo com baixos teores de amilose. No caso das raízes de mandioca, Asaoka et al. (1992) não encontraram relação entre qualidade de cocção e conteúdo de amilose, cristalinidade, digestibilidade por amilases ou tamanho dos grânulos de amido. 


\subsubsection{Tamanho e formato dos grânulos de amido}

Os grânulos de amidos extraídos das raízes de mandioca de plantas com 12 e 15 meses de idade podem ser visualizados nas Figuras 9 e 10 por fotomicrografias feitas por análise de imagem em microscópio óptico.

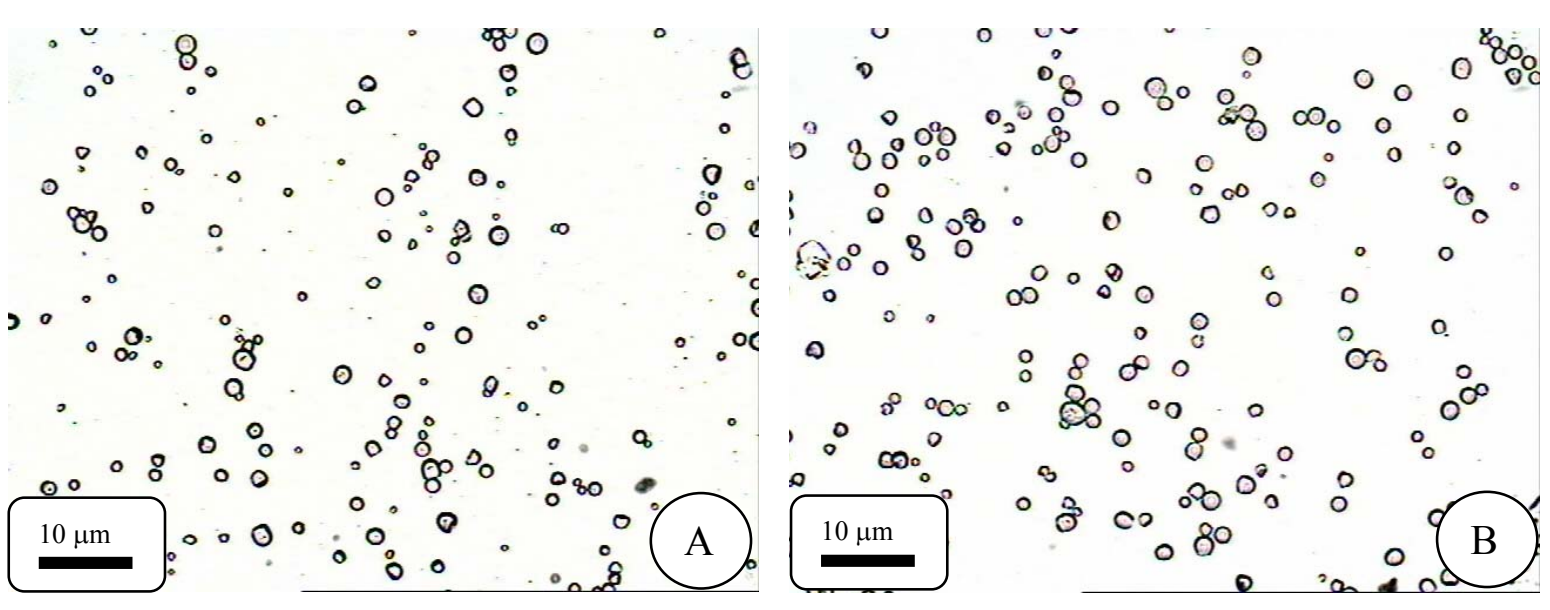

Figura 9 - Imagem dos grânulos de amido (aumento de 10 vezes) extraído de raízes de plantas de: 12 meses (A) e 15 meses (B)

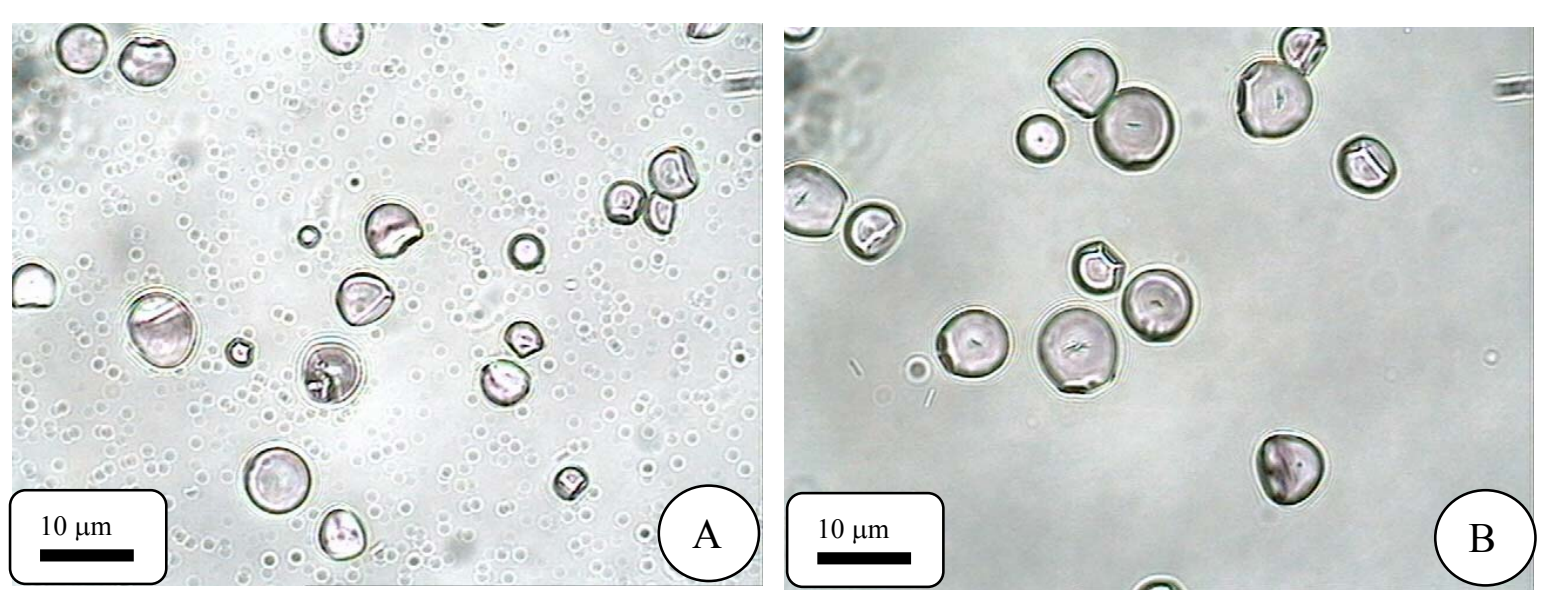

Figura 10 - Imagem dos grânulos de amido (aumento de 40 vezes) extraído de raízes de plantas de: 12 meses (A) e 15 meses (B) 
Como visualizados nas fotos, os grânulos de amido não são uniformes quanto ao formato e tamanho, o que se encontra em acordo com a literatura. Os formatos dos grânulos de amido encontrados nas raízes foram os arredondados, convexo-bicôncavo, cupuliforme e mitriforme, formatos estes também citados por Rosenthal (1972) para raízes de mandioca. Nos períodos avaliados, os grânulos de amido não apresentaram diferença entre si quanto aos formatos.

Em função da variabilidade de formatos apresentados por este cultivar, a mensuração dos tamanhos dos grânulos foi realizada e expressa como a média dos diâmetros maiores e menores e ainda, média das áreas superficiais específicas. Os resultados obtidos são apresentados na Tabela 6 .

Tabela 6. Tamanho dos grânulos de amido das raízes de plantas de mandioca do cultivar IAC 576-70, com 12 e 15 meses de idade.

\begin{tabular}{lcc}
\hline \multicolumn{1}{c}{ Mensuração dos grânulos } & 12 meses & 15 meses \\
\hline Diâmetro menor $(\mu \mathrm{m})$ & $10,9^{\mathrm{a}} \pm 3,02$ & $12,8^{\mathrm{b}} \pm 3,27$ \\
Diâmetro maior $(\mu \mathrm{m})$ & $12,8^{\mathrm{a}} \pm 3,27$ & $15,0^{\mathrm{b}} \pm 2,36$ \\
Área superficial específica $\left(\mu \mathrm{m}^{2}\right)$ & $108,2^{\mathrm{a}} \pm 59,54$ & $141,2^{\mathrm{b}} \pm 34,8$ \\
\hline
\end{tabular}

Nota: médias com letras diferentes na mesma linha diferem entre si em nível de 5\% de probabilidade pelo teste de Tukey

As raízes de plantas com 12 meses apresentaram grânulos de amido de variando de 4 a $20 \mu \mathrm{m}$ (diâmetro menor), de 5 a $25 \mu \mathrm{m}$ (diâmetro maior) e 12 a $325 \mu \mathrm{m}^{2}$ (área superficial específica). Já os grânulos de amido de raízes de plantas com 15 meses apresentaram 6 a $22 \mu \mathrm{m}$ (diâmetro menor), 7 a $28 \mu \mathrm{m}$ (diâmetro maior) e 30 a $380 \mu \mathrm{m}^{2}$ (área superficial específica).

As plantas de mandioca apresentam crescimento indeterminado, tendo sempre grânulos de tamanho pequeno, médio e grande (Daiuto, 2000). Nos períodos de colheitas avaliados no presente experimento, os grânulos de amido passaram por alterações 
significativas de tamanho. Conforme as plantas se desenvolveram, os grânulos aumentaram de tamanho, muito provavelmente em função da fisiologia do vegetal que, aos 12 meses correspondia ao período vegetativo e aos 15 meses ao início do período de repouso.

Nas Figuras 11 e 12 a distribuição de freqüência dos tamanhos de grânulos sob a forma de histogramas permite melhor visualização de como se deu esse crescimento.
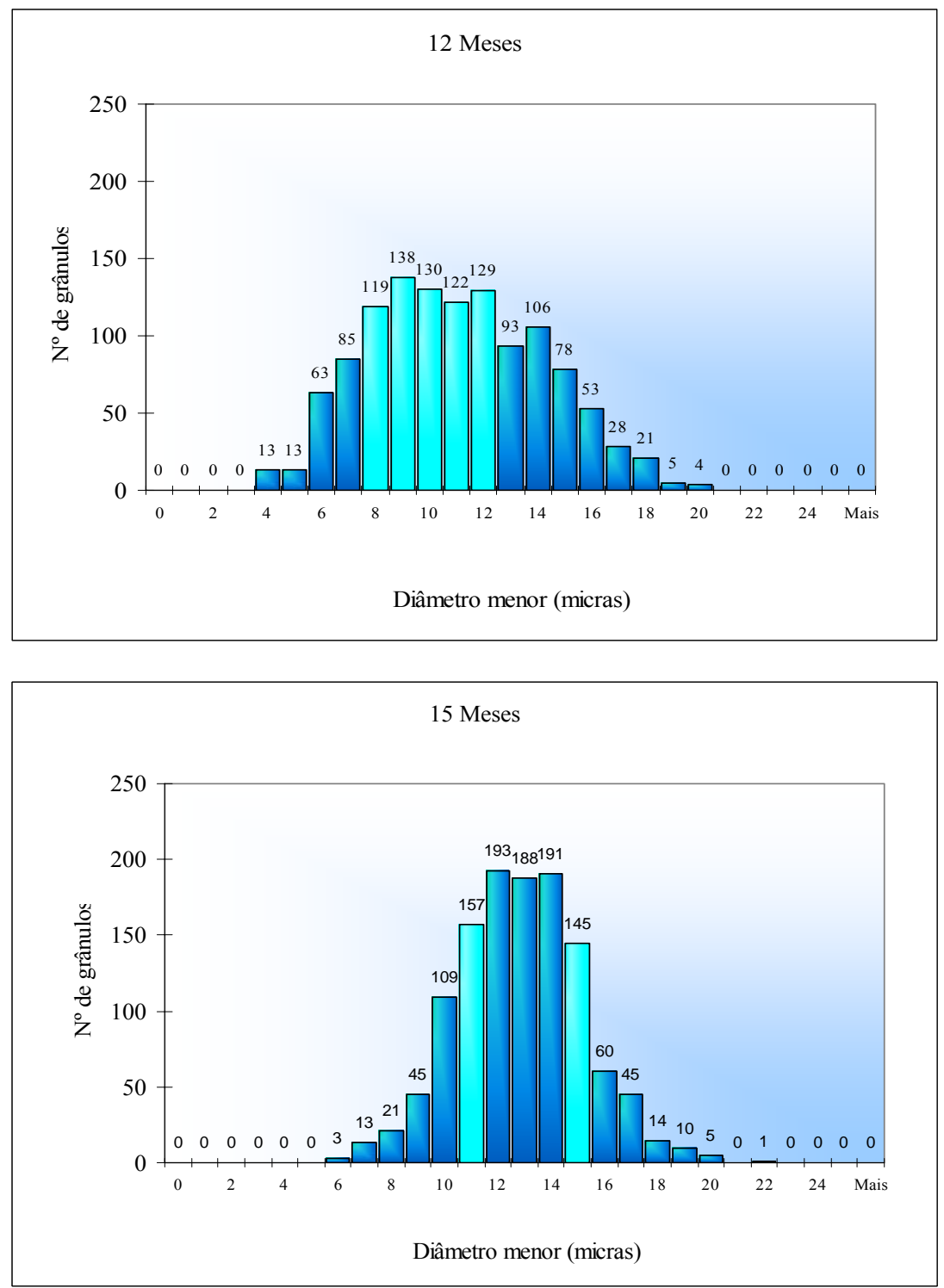

Figura 11 - Histogramas para diâmetro menor dos grânulos de amido de raízes de plantas de mandioca com 12 e 15 meses 

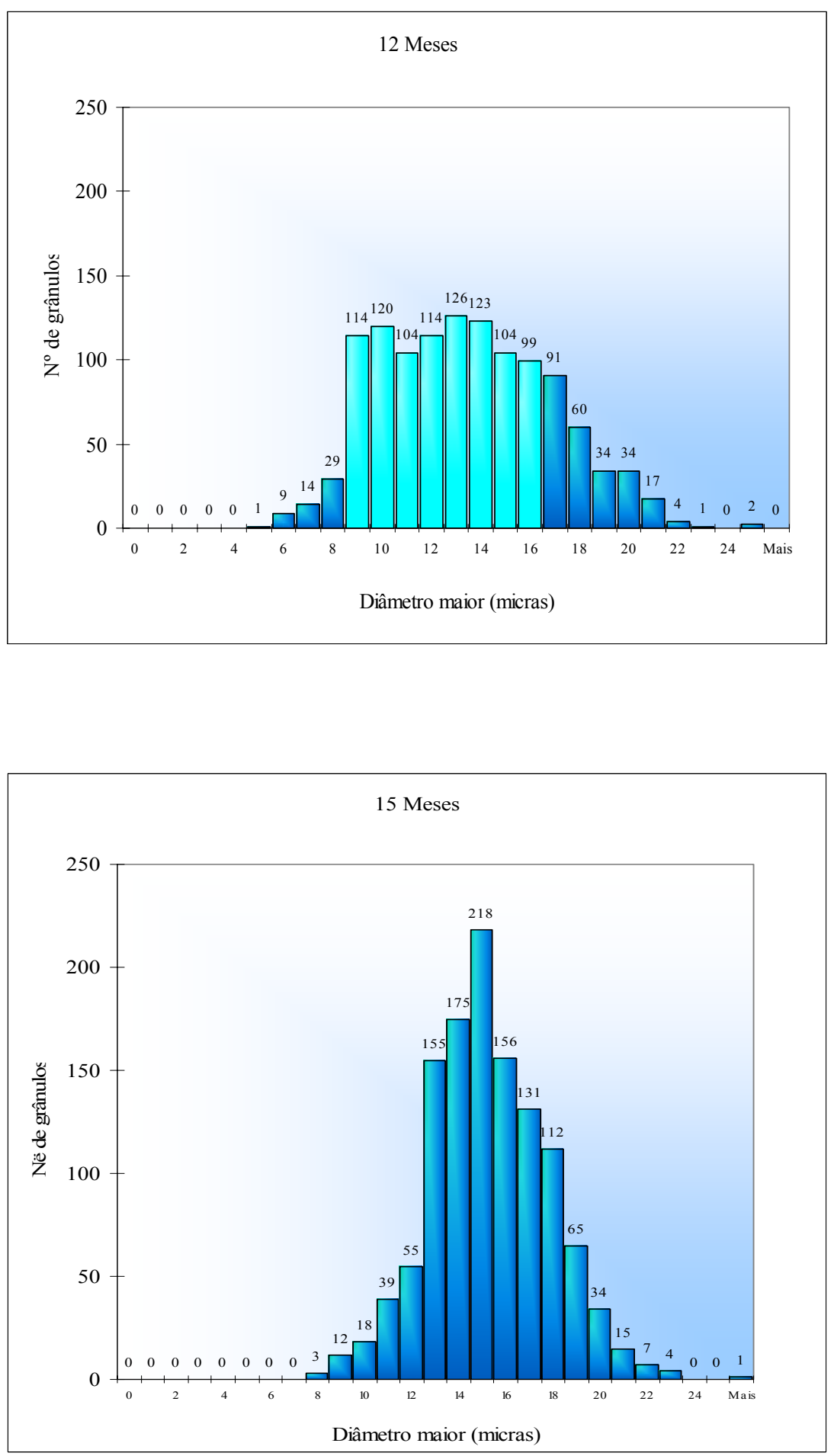

Figura 12 - Histogramas para diâmetro maior dos grânulos de amido de raízes de plantas de mandioca com 12 e 15 meses 
Aos 12 meses de idade, as raízes de mandioca apresentaram grânulos de amido com diâmetro menor predominante variando entre 6 e $18 \mu \mathrm{m}$ e diâmetro maior entre 9 e $18 \mu \mathrm{m}$. Aos 15 meses de idade as plantas apresentavam grânulos de amido com diâmetro menor predominante entre 10 e $15 \mu \mathrm{m}$ e diâmetro maior entre 13 e $18 \mu \mathrm{m}$.

Os grânulos de amido de raízes de plantas com 12 meses apresentaram maior amplitude de variação de tamanho que os de plantas com 15 meses. Pelos histogramas de todos os parâmetros avaliados (diâmetro menor, diâmetro maior) pode se visualizar que os grânulos de amido de plantas mais novas se distribuíram mais pelas várias classes de tamanho e nas mais velhas ficaram mais concentrados em classes de tamanho superior. Essa maior amplitude decorre, muito possivelmente, do momento fisiológico da planta, onde aos 12 meses a atividade era maior, havendo grânulos de menor tamanho sendo depositados e também utilizados pelo vegetal e aos 15 meses, apenas depositado.

\subsubsection{Propriedades da pasta}

As propriedades de pasta dos amidos extraídos de raízes de plantas do cultivar IAC 576-70 com 12 e 15 meses são apresentadas na Figura 13 e Tabela 7.

O perfil viscoamilográfico do amido das raízes de plantas aos 12 meses apresentou pico de viscosidade mais arredondado e o de plantas aos 15 meses foi mais agudo. Picos com formatos mais agudos dizem respeito a grânulos de amido com propriedades de expansão/ruptura mais uniformes durante o tratamento hidrotérmico e picos mais achatados significam o inverso. Os grânulos de amido também apresentaram aos 12 meses uma variação de tamanho mais ampla que aos 15 meses. Tal comportamento pode ser conseqüência dos períodos físiológicos do vegetal, de constante atividade metabólica na fase vegetativa aos 12 meses e de repouso aos 15 meses, alterando não somente o tamanho, mas também outras propriedades dos grânulos que estão associadas ao comportamento dos amidos em tratamento hidrotérmico. 


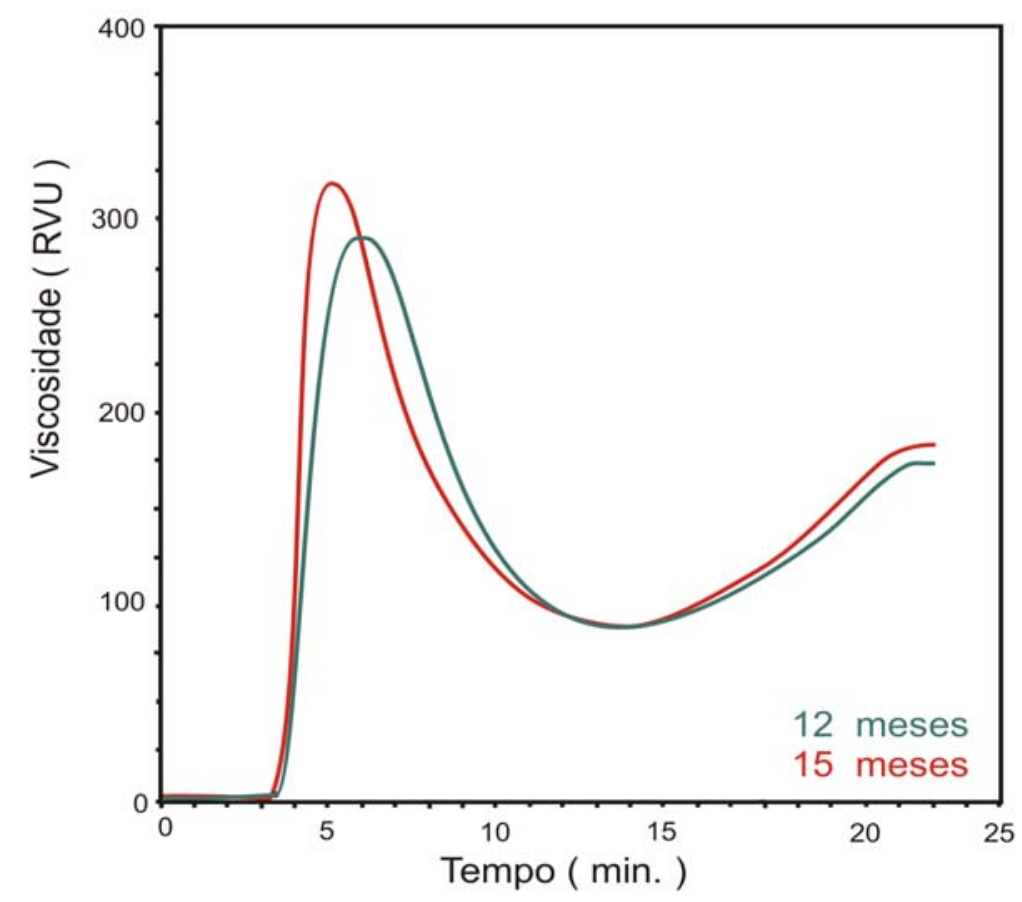

Figura 13 - Curvas viscoamilográficas obtidas pelo RVA para amidos extraídos de raízes do cultivar IAC 576-70, com 12 e 15 meses de idade

Tabela 7. Propriedades das pastas de amidos extraídos de raízes de plantas com 12 e 15 meses de idade

\begin{tabular}{lcc}
\hline \multicolumn{1}{c}{ Parâmetros } & \multicolumn{2}{c}{ Média e desvio padrão } \\
\cline { 2 - 3 } & 12 meses & 15 meses \\
\hline Viscosidade máxima (RVU) & $288^{\mathrm{a}} \pm 18,8$ & $318^{\mathrm{b}} \pm 8,2$ \\
Quebra na viscosidade (RVU) & $18^{\mathrm{a}} \pm 5,2$ & $23^{\mathrm{a}} \pm 1,2$ \\
Viscosidade final (RVU) & $174^{\mathrm{a}} \pm 7,2$ & $179^{\mathrm{a}} \pm 9,4$ \\
Tendência a retrogradação (RVU) & $86^{\mathrm{a}} \pm 5,1$ & $94^{\mathrm{a}} \pm 4,5$ \\
Tempo de pico (min.) & $6^{\mathrm{a}} \pm 0,1$ & $5^{\mathrm{b}} \pm 0,1$ \\
Temperatura de pasta $\left({ }^{\circ} \mathrm{C}\right)$ & $66^{\mathrm{a}} \pm 0,3$ & $66^{\mathrm{a}} \pm 0,4$ \\
\hline
\end{tabular}

Nota: médias com letras diferentes na mesma linha diferem entre si em nível de $5 \%$ de probabilidade pelo teste de Tukey 
Nas mesmas condições de análise Peroni (2003) encontrou o valor de 263 RVU para o pico de viscosidade em amido de mandioca, menor que o encontrado no presente estudo.

Considerando os perfis de viscosidade e as propriedades de pasta no presente estudo pode se observar que a diferença mais expressiva entre os amidos de plantas em ambas as idades ocorreu para o pico de viscosidade (formato e valor). O amido extraído de raízes de plantas com 15 meses mostraram maior viscosidade e menor tempo de pico. Plantas nesta idade ou fase fisiológica também apresentaram maior proporção de grânulos de amido de maior tamanho.

De acordo com Zeng et al. (1997) e Peterson \& Fulch (2001) a viscosidade máxima se correlaciona negativamente com o teor de amilose do amido. Estes autores citam que em grânulos com menor teor de amilose ocorre maior inchamento, com conseqüente queda na quantidade de água livre da suspensão. Apesar de não ter sido estatisticamente significativa a diferença quanto aos teores de amilose nas plantas estudadas, o amido desse cultivar aos 15 meses de idade apresentou menor percentual dessa macromolécula.

\subsection{Tempo de cocção das raízes e adesão celular}

A avaliação do grau de cozimento raízes de mandioca é realizada em função do tempo necessário para que ocorra o amolecimento de pedaços imersos em água fervente. O tempo ideal de cocção e a adesividade celular durante o cozimento das raízes de plantas nas idades estudadas são mostrados na Tabela 8. 
Tabela 8. Tempo ideal de cocção e adesão celular das raízes de mandioca do cultivar IAC 576-70 aos 12 e aos 15 meses de idade

\begin{tabular}{lcc}
\hline \multicolumn{1}{c}{ Variáveis } & \multicolumn{2}{c}{ Média e desvio padrão } \\
\cline { 2 - 3 } & 12 meses & 15 meses \\
\hline Tempo ideal de cocção (minutos) & $16,0^{\mathrm{a}} \pm 0,00$ & $21,0^{\mathrm{b}} \pm 1,41$ \\
Desintegração celular (\%) & $19,1^{\mathrm{a}} \pm 0,35$ & $6,8^{\mathrm{b}} \pm 1,13$ \\
\hline
\end{tabular}

Nota: médias com letras diferentes na mesma linha diferem entre si em nível de 5\% de probabilidade pelo teste de Tukey

Raízes das plantas em ambas as idades atingiram o que é considerado pela metodologia como ponto ideal de cozimento, ou seja, o tempo onde metade das agulhas mais uma conseguem penetrar nas mesmas. Houve, entretanto, diferenças significativas no tempo para as raízes de ambas as idades chegarem a esse ponto de cocção. O tempo ideal de cocção das raízes com 12 meses, 16 minutos, foi menor e estatisticamente diferente do tempo daquelas de 15 meses, que foi de 21 minutos. As raízes com ambas idades estudadas, de acordo com a classificação de Vilpoux \& Cereda (2003), apresentaram o cozimento, que em nível industrial, seriam consideradas tipo A. O tipo A é o que apresenta cozimento normal, em até 30 minutos, à temperatura de fervura da água e em pressão ambiente. De acordo com a classificação proposta por Pereira et al. (1985), as raízes de plantas com 12 meses seriam consideradas de cozimento bom, enquanto que as raízes de plantas com 15 meses seriam consideradas de cozimento regular.

Considerando o que afirmam Vilpoux \& Cereda (2003), que o período de repouso é o melhor para cozimento das raízes de mandioca, a resposta obtida no presente experimento não correpondeu, pois as raízes de plantas com 15 meses (período de repouso) apresentaram maior tempo de cocção.

Os períodos em que a planta de mandioca apresenta maior dificuldade de cocção correspondem ao período onde as raízes estão com maiores teores de umidade, 
ou seja, com menores teores de massa seca (Vilpoux \& Cereda, 2003). No presente trabalho, também não foi evidenciada diferença estatística entre os teores de umidade das amostras de 12 e 15 meses, embora tenha sido observada variação quanto ao tempo de cocção das mesmas.

A porcentagem de desintegração celular do material cozido após agitação, que é uma medida da adesão celular dos tecidos da raiz, é mostrada na Tabela 5. As raízes de plantas com 12 meses, que cozeram mais rapidamente, apresentaram também maior perda de massa seca (maior percentual de desintegração celular) devido à estrutura celular mais frágil ou menor adesividade celular.

Segundo Binner et al. (2000) a perda de adesividade intercelular na lamela média é devida à destruição parcial do gel péctico quando o vegetal é cozido. Sterling (1963) atribuiu o desenvolvimento de uma rápida maciez dos tecidos vegetais ao fenômeno de expansão e solubilização das substâncias pécticas, com conseqüente queda de integridade da lamela média.

Desse modo, no presente estudo, a diferença quantitativa no teor das substâncias pécticas entre raízes de plantas em ambas as idades poderia estar relacionada com o tempo de cocção e qualidade de massa apresentada.

Bhatty (1995) levantou também a hipótese de que a presença de íons bivalentes favorece a formação de pectatos insolúveis, formados a partir das substâncias pécticas e teriam a função de dificultar a desagregação celular durante o cozimento com conseqüente redução na firmeza dos tecidos vegetais. Favaro (2003) também sugere que menor quantidade de cátions bivalentes, como cálcio e magnésio, e maior quantidade de potássio, podem ter influencia sobre as ligações entre polissacarídeos pécticos na lamela média e resultar em maior perda de adesão celular durante o cozimento de raízes de mandioca. Favaro (2003) detectou diferenças significativas para teores de minerais nas raízes de variedades que apresentaram tempos de cocção diferentes. No trabalho desse autor nas variedades que apresentaram menor tempo de cocção foi determinada quantidade menor de cálcio e magnésio e maior de potássio. Entretanto, o autor não verificou diferença estatística nos teores de minerais em raízes de plantas de uma mesma variedade, mas com diferentes idades. 
No presente experimento, embora se tenha tempo de cocção diferente para raízes de plantas com 12 e 15 meses, os teores de minerais nas mesmas não apresentaram variação significativa nas idades estudadas.

\subsection{Propriedades da pasta das raízes cozidas, desidratadas e moídas}

As raízes de mandioca cozidas e desidratadas foram moídas e avaliadas quanto às propriedades de pasta pelo Rapid Visco Analyser, com o objetivo de correlacionar tais propriedades com a cocção das raízes e tipo de massa gerada. Os perfis viscoamilográficos obtidos para este material podem ser visualizados pela Figura 14, onde também são apresentados, para fins de comparação, os respectivos materiais crus, ou seja, raízes cruas, desidratadas e moídas.

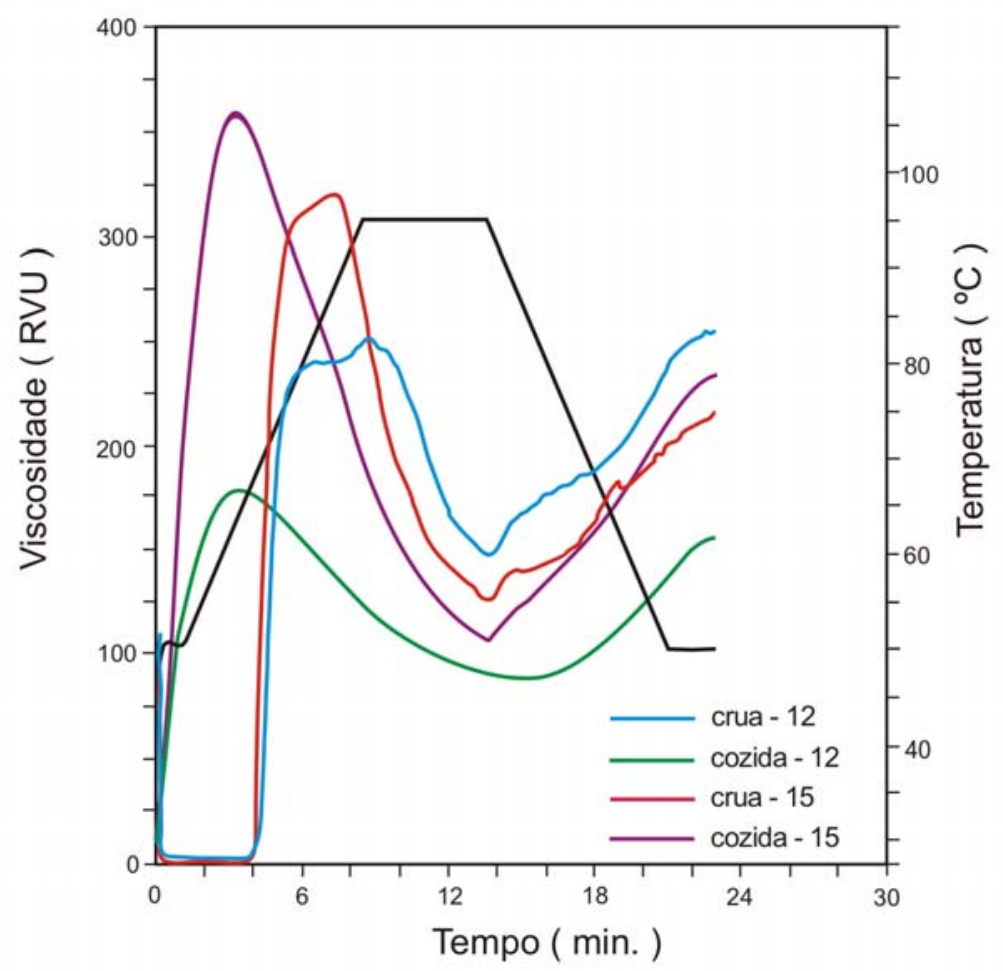

Figura 14 - Perfis de viscosidade (RVA) das raízes cruas, desidratadas e moídas e das raízes cozidas, desidratadas e moídas, de plantas de mandioca aos 12 e aos 15 meses de idade 
$\mathrm{Na}$ Tabela 9 são apresentados os pontos críticos de viscosidade, extraídos das curvas obtidas pelo RVA para farinhas de raízes cruas, desidratadas e moídas e raízes cozidas, desidratadas e moídas.

Tabela 9. Propriedades da pasta de raízes de mandioca cruas, desidratadas e moídas e raízes cozidas, desidratas e moídas

\begin{tabular}{lcccc}
\hline \multirow{2}{*}{\multicolumn{1}{c}{ Parâmetros }} & \multicolumn{4}{c}{ Média e desvio padrão } \\
\cline { 2 - 5 } & \multicolumn{2}{c}{12 meses } & \multicolumn{2}{c}{15 meses } \\
\cline { 2 - 5 } & $\begin{array}{c}\text { Raízes cruas, } \\
\text { desidratadas e } \\
\text { moídas }\end{array}$ & $\begin{array}{c}\text { Raízes cozidas, } \\
\text { desidratadas e } \\
\text { moídas }\end{array}$ & $\begin{array}{c}\text { Raízes cruas, } \\
\text { desidratadas e } \\
\text { moídas }\end{array}$ & $\begin{array}{c}\text { Raízes cozidas, } \\
\text { desidratadas e } \\
\text { moídas }\end{array}$ \\
\hline Viscosidade máxima (RVU) & $252 \pm 2,06$ & $184 \pm 5,59$ & $320 \pm 1,35$ & $354 \pm 5,30$ \\
Quebra na viscosidade (RVU) & $106 \pm 2,83$ & $101 \pm 2,77$ & $196 \pm 1,82$ & $243 \pm 0,71$ \\
Viscosidade final (RVU) & $255 \pm 1,12$ & $154 \pm 3,24$ & $212 \pm 2,06$ & $238 \pm 6,77$ \\
Tendência a retrogradação (RVU) & $109 \pm 1,89$ & $74 \pm 2,00$ & $88 \pm 1,59$ & $129 \pm 0,25$ \\
Tempo de pico (min.) & $8,7 \pm 0,00$ & $3,6 \pm 0,49$ & $7,2 \pm 0,05$ & $3,4 \pm 0,14$ \\
\hline
\end{tabular}

O amido das raízes de plantas aos 12 meses, como visto na Figura 14 (item 4.2.3.), apresentou pico de menor viscosidade e mais arredondado que o de plantas aos 15 meses. No caso do perfil de RVA das raízes cruas, desidratadas e moídas na Figura 15 foi observada tendência similar, ou seja, a curva para plantas aos 12 meses apresentou pico menor de viscosidade e formato achatado, enquanto que a de plantas aos 15 meses apresentou pico de maior viscosidade e mais agudo. A comparação destes perfis de viscosidade evidenciou a importância das características do amido no comportamento reológico das raízes. Também de grande importância é a composição das raízes, principalmente no que diz respeito à quantidade de amido, que foi significativamente diferente entre as idades ou períodos fisiológicos estudados.

As raízes cozidas, desidratadas e moídas mostraram curvas mais definidas, apresentando viscosidade a frio e pico em tempo curto, comportamento já esperado, uma vez que se trata de material previamente cozido, um produto pré-gelificado. Ao se 
comparar as curvas do material elaborado com raízes cruas com o elaborado com raízes cozidas, oriundas de plantas da mesma idade, as diferenças em termos de composição (teor de amido) e propriedades intrínsecas dos grânulos são minimizadas. Restam então, diferenças quanto às propriedades dos amidos que foram pré-gelificados durante a cocção inicial das raízes, diferenças quanto aos teores e propriedades do amido granular remanescente desse processo e ainda pode-se considerar diferenças quanto à ação de enzimas autóctones das raízes. Estas últimas são enzimas amilolíticas, naturalmente presentes em vegetais amiláceos, algumas termo-resistentes, citadas em Vilpoux \& Cereda (2003). Tais enzimas podem estar atuando de modo diferenciado nas plantas de 12 e de 15 meses, uma vez tratam-se de períodos fisiológicos diferentes do vegetal.

O comportamento reológico das raízes cozidas, desidratadas e moídas de plantas em diferentes idades foi desuniforme com relação às respectivas raízes cruas, desidratadas e moídas. O material obtido de raízes cozidas de plantas de 12 meses, cujo tempo de cocção foi inferior ao tempo das plantas de 15 meses, apresentou pico de viscosidade consideravelmente inferior às sua correspondente crua. Já as raízes cozidas, desidratadas e moídas de plantas aos 15 meses, de cozimento mais lento, apresentaram pico superior às correspondentes cruas, o que talvez seja indicativo de que não tenha ocorrido gelificação total dos grânulos durante o processo de cozimento e agora, no viscoamilógrafo, esta reação é levada a efeito.

\subsection{Avaliação histoquímica das raízes cruas e cozidas}

Os resultados obtidos pela avaliação histoquímica realizada em amostras de raízes de plantas com 12 meses de idade, tanto in natura como cozidas, podem ser avaliados pelas fotomicrografias apresentadas nas Figuras de 15 a 18. Os resultados obtidos para raízes de plantas com 12 meses e 15 meses foram similares, razão pela qual são apresentadas apenas as microfotografias das raízes de plantas com 12 meses.

A Figura 15 evidencia a presença de pectina na parede celular pelo teste do Vermelho de Rutênio, tanto no material cru como cozido. 

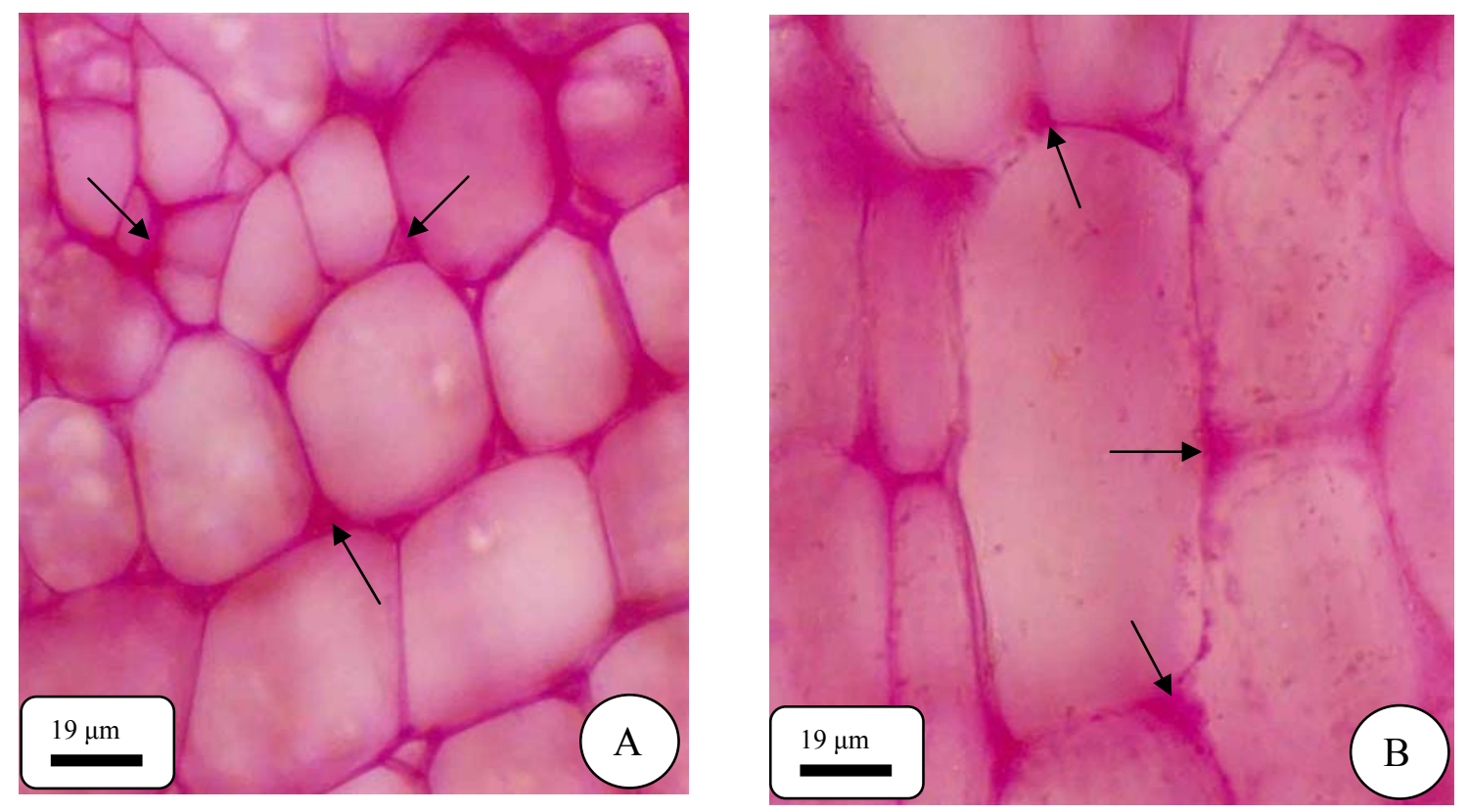

Figura 15 - Secções transversais medianas da raiz adventícia de Manihot esculenta Crantz cultivar IAC 576-70, de plantas com 12 meses de idade, tuberizada. Aspecto geral do cilindro vascular em estrutura secundária. Vermelho de rutênio evidenciando pectina na parede celular (setas) de raízes cruas (A) e raízes cozidas $(\mathrm{B})$

Pelos testes histológicos a pectina está presente na lamela média das raízes das plantas de ambas as idades, exercendo função cimentante entre as células. A avaliação quantitativa (item 4.1.), entretanto, mostrou que este componente está presente em maiores teores nas plantas com 12 meses. O teor de pectina solúvel nas raízes desta idade não apresentou diferença significativa, entretanto, foi numericamente superior.

Além do teor de pectina presente nas raízes, a estrutura e composição dos polissacarídeos pécticos podem também estar relacionados com tempo de cocção e maciez do vegetal. Essa hipótese foi sugerida por Marle et al. (1997), na qual essas diferenças na estrutura e composição influenciam a intensidade da reação de quebra dos polímeros pécticos que conduz ao amolecimento do vegetal. Essa quebra é a despolimerização por $\beta$-eliminação da pectina intercelular citada por Stolle-Smits et al. 
(1995), e que confirmaria a hipótese levantada por Normanha (1988) de que o rompimento incompleto das ligações entre moléculas de derivados pécticos que unem a lamela média às paredes primárias das células e aos demais elementos do parênquima seria a causa de um cozimento deficiente das raízes de mandioca. Explicaria também uma das hipóteses levantadas por Vilpoux \& Cereda (2003), de que alterações na parede celular, dificultando a deformação da mesma, impedem o inchamento dos grânulos de amido e conseqüentemente uma boa gelificação, fator característico de um bom cozimento.

As fotografias das amostras tratadas com floroglucina estão registradas na Figura 16 (A e B).
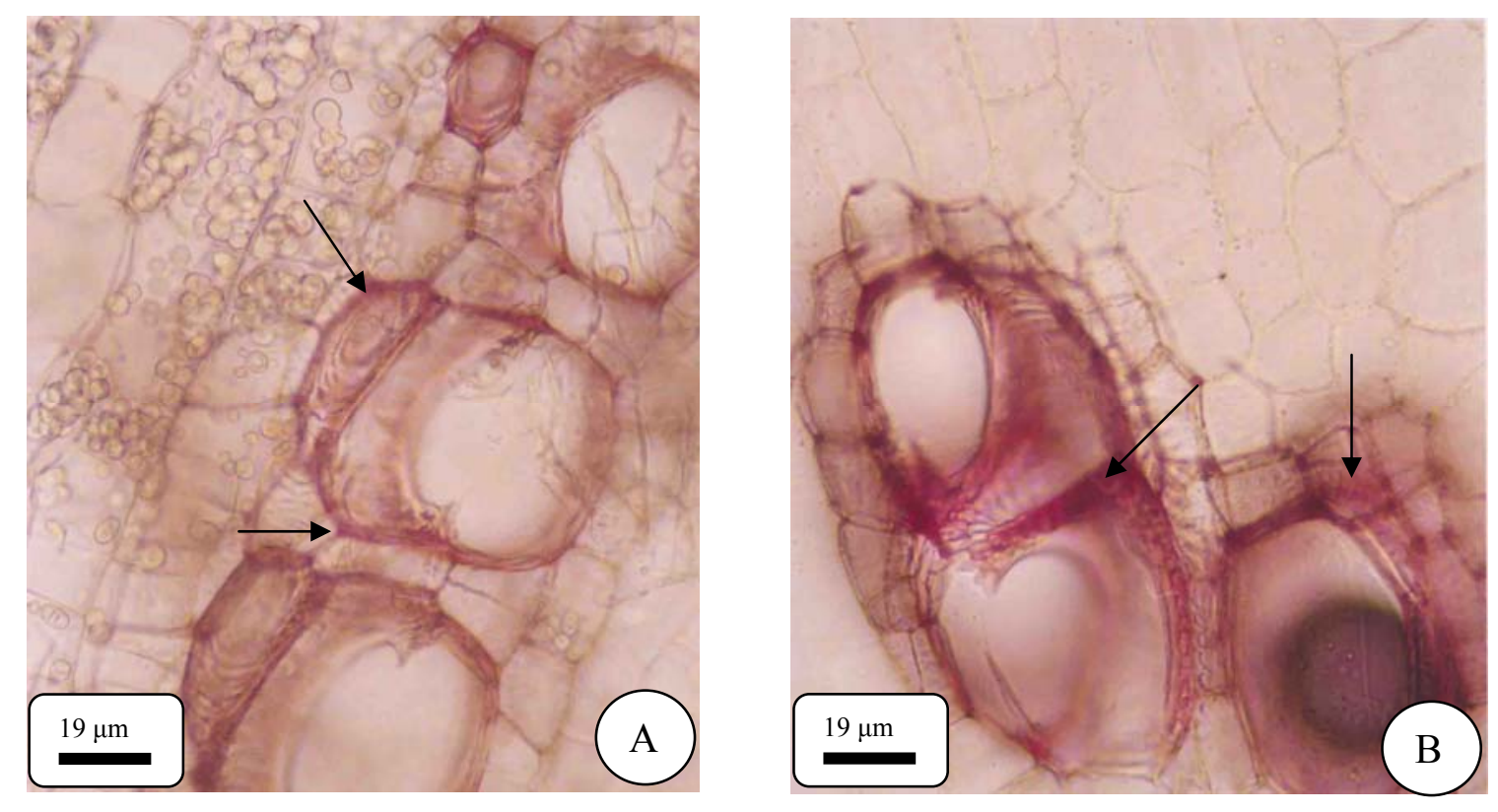

Figura 16 - Secções transversais medianas da raiz adventícia de Manihot esculenta Crantz cultivar IAC 576-70, de plantas com 12 meses de idade, tuberizada. Aspecto geral do cilindro vascular em estrutura secundária. Floroglucina evidenciando parede celular secundária lignificada de elemento de vaso (setas). Raiz crua (A). Raiz cozida (B) 
Para os dois tratamentos foi observada a presença de lignina apenas nos vasos condutores, o que indica que não ocorreu a lignificação das células e, portanto, este componente não estaria interferindo nas possíveis variações na textura e na qualidade de massa cozida. A lignificação de sementes de leguminosas, segundo Nascimento (1992), é a deposição de lignina na lamela média, o que reduz a permeabilidade aquosa da parede celular e promove maior elasticidade das paredes, reduzindo a absorção de água durante a cocção, o que influencia a gelificação do amido e, conseqüentemente, o enrijecimento do vegetal.

A Figura 17 apresenta o resultado das amostras tratada com cloreto férrico, que tem a finalidade de evidenciar compostos fenólicos através de pontos de coloração azul.
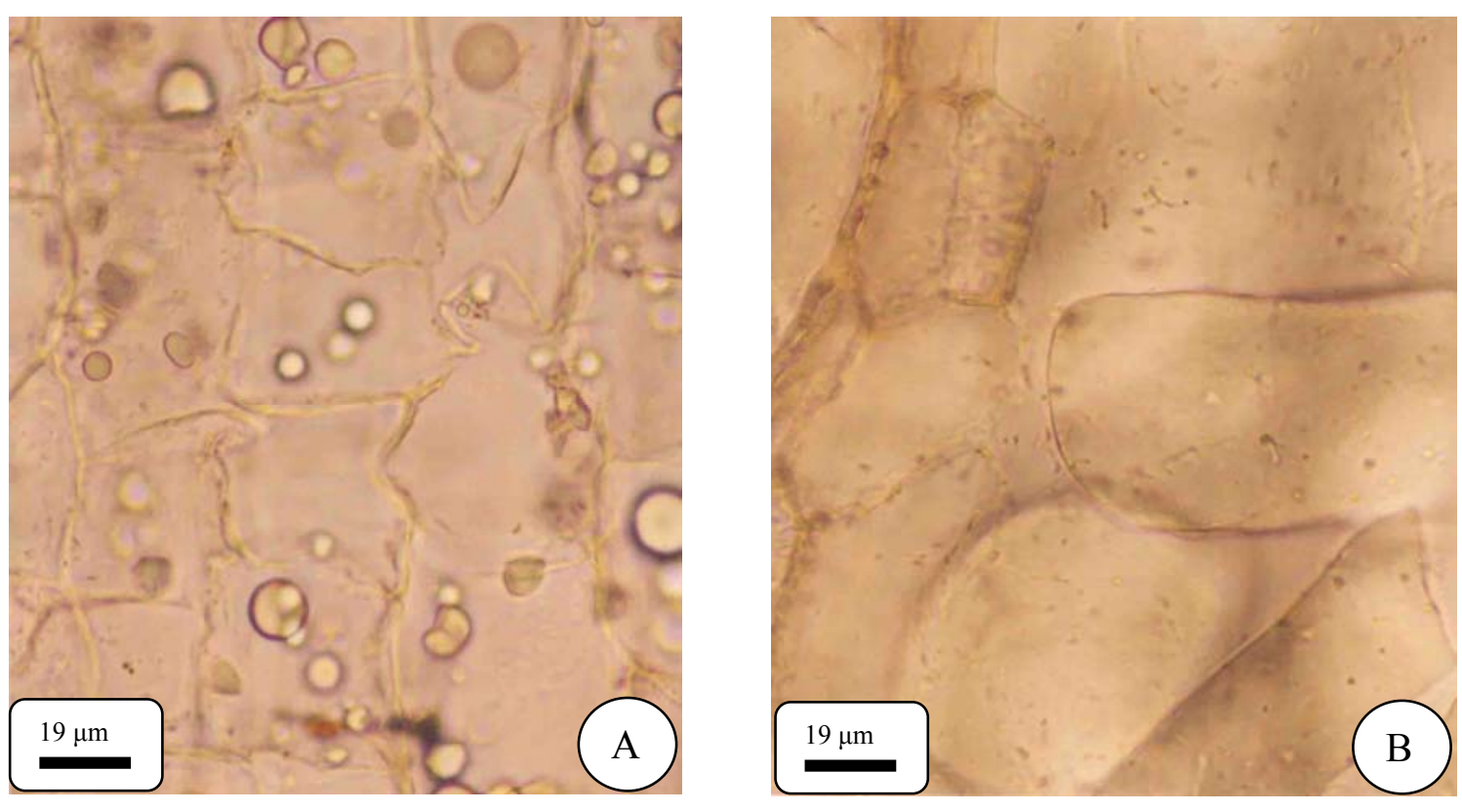

Figura 17 - Secções transversais medianas da raiz adventícia de Manihot esculenta Crantz cultivar IAC 576-70, de plantas com 12 meses de idade, tuberizada. Aspecto geral do cilindro vascular em estrutura secundária. Cloreto férrico para a determinação de compostos fenólicos (coloração azul não evidenciada). Raiz crua (A). Raiz cozida (B) 
Este teste histológico não evidenciou a coloração azul, o que expressa resultado negativo para a presença de compostos fenólicos. Como os compostos fenólicos são precursores de lignina, a ausência desse compostos no parênquima confirma o resultado do teste de floroglucina, que não identificou a presença de lignina no tecido parenquimático (apenas nos vasos condutores). Desse modo, torna-se pouco provável a influência deste componente das fibras, sobre o tempo necessário para cocção ou textura das raízes de plantas em ambas as idades.

A Figura 18 evidenciou a presença de substâncias lipídicas na parede celular das raízes cruas e nas células e parede celular de raízes cozidas de plantas em ambas as idades. A presença na parede celular de substâncias lipídicas, que apresentam caráter apolar, poderia afetar a passagem de água pela parede, tendo-se água insuficiente para gelificar o amido. Isto explicaria a hipótese levantada por Vilpoux \& Cereda (2003) para explicar problemas de cocção em raízes, que se baseia na não penetração de água no interior das células, o que impede a gelificação do amido.
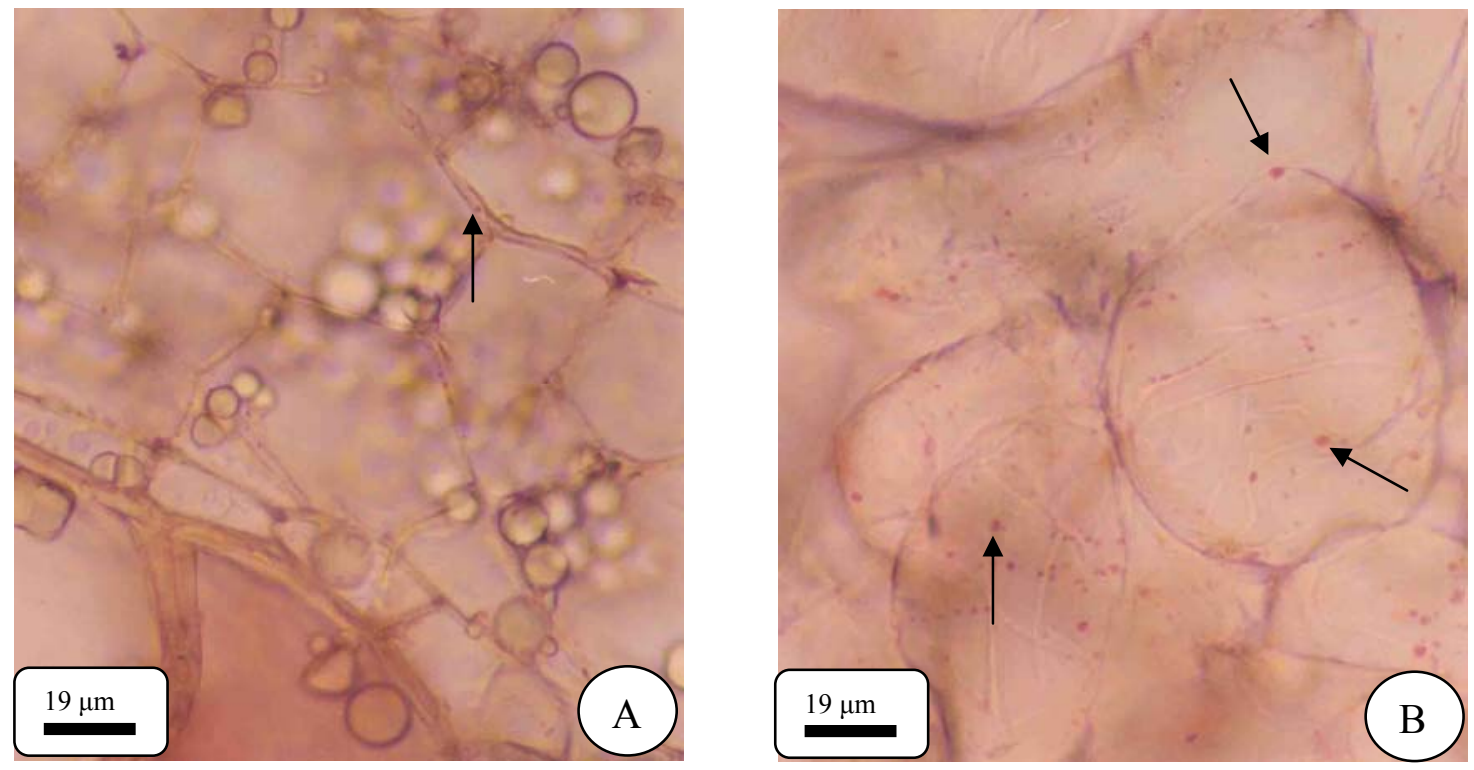

Figura 18 - Secções transversais medianas da raiz adventícia de Manihot esculenta Crantz cultivar IAC 576-70, de plantas com 12 meses de idade, tuberizada. Aspecto geral do cilindro vascular em estrutura secundária. Sudan IV evidenciando presença de lipídeos na parede celular de raiz crua e nas células de raiz cozida (setas). Raiz crua (A). Raiz cozida (B) 
Os testes histoquímicos são indicativos da presença ou ausência de componentes considerados importantes para a cocção e textura dos vegetais. Além deste tipo de indicação, ao se comparar raízes cruas com cozidas, pode-se observar (fotos das Figuras 15, 16, 17 e 18) propriedades como a expansão dos grânulos de amido durante o tratamento hidrotérmico, que se tornam transparentes e inchados. Em virtude da expansão granular ocorreu arredondamento das células e até mesmo, deslizamento, gerando desorganização do tecido. O tecido de raízes que apresentaram menor tempo de cozimento (12 meses) não apresentou pelos testes histológicos dilaceração intensa, embora tenha apresentado maior percentual de desintegração celular.

\subsection{Textura das raízes cruas e cozidas}

A textura se coloca entre os atributos importantes das raízes de mandioca cozidas, sendo decisiva para a determinação do ponto de cocção das amostras.

Os resultados quanto à resistência ao cisalhamento, dureza e adesividade das raízes de mandioca são apresentados na Tabela 10.

Os valores da resistência ao cisalhamento apresentado pelas raízes cruas, em ambas as idades de plantas, foram inferiores aos 18,6 lbf/g obtidos por Di-Tanno (2001) para raízes variedade Ouro do Vale, nas mesmas condições de análise.

No presente trabalho, as diferenças observadas para tempos de cocção podem ser explicadas por diferenças nas características estruturais das raízes in natura das plantas. Raízes que demoraram menos para cozer (12 meses) apresentaram textura mais macia, tanto quando cruas como quando cozidas. 
Tabela 10. Textura das raízes de mandioca de plantas do cultivar IAC 576-70 aos 12 e aos 15 meses de idade

\begin{tabular}{lcc}
\hline \multicolumn{1}{c}{ Variáveis } & \multicolumn{2}{c}{ Média e desvio padrão } \\
\cline { 2 - 3 } & 12 meses & 15 meses \\
\hline Resistência ao cisalhamento $(\mathrm{lbf} / \mathrm{g})$ & $11,8^{\mathrm{a}} \pm 0,87$ & $14,0^{\mathrm{b}} \pm 1,49$ \\
- raízes cruas & $2,2^{\mathrm{a}} \pm 0,48$ & $2,9^{\mathrm{b}} \pm 0,72$ \\
- raízes cozidas & $1,5^{\mathrm{a}} \pm 0,08$ & $2,1^{\mathrm{a}} \pm 0,46$ \\
- raízes cozidas após congelamento & $1259,8^{\mathrm{a}} \pm$ & $2774,2^{\mathrm{b}} \pm$ \\
Dureza das raízes cozidas após congelamento & 463,34 & 293,22 \\
(grama-força) & $-12,0^{\mathrm{a}} \pm 7,29$ & $-5,2^{\mathrm{a}} \pm 3,57$ \\
Adesividade das raízes cozidas após congelamento & \\
(grama-força) & & \\
\hline
\end{tabular}

Nota: médias com letras diferentes na mesma linha diferem entre si em nível de 5\% de probabilidade pelo teste de Tukey

Raízes de plantas aos 15 meses, com maior dificuldade de cocção apresentaram maiores valores de dureza (resistência ao cisalhamento), tanto cruas como cozidas. Durante a cocção essas raízes não se desintegraram muito, o que revela elevada adesão celular, ou seja, as mesmas preservaram suas estruturas e conseqüentemente, suas texturas. Além disto, as raízes de plantas com 15 meses apresentaram teores mais elevados de fibras totais. Eggleston \& Asiedu (1992) também encontraram correlação inversa alta entre a porcentagem de desintegração celular e a força de compressão em raízes de mandioca cozidas.

Pelos dados de textura (Tabela 10), após o cozimento das raízes congeladas foi observado um decréscimo na resistência das raízes ao cisalhamento. Essa menor resistência pode ser atribuída ao rompimento celular devido à formação de cristais de gelo nos tecidos durante o processo de congelamento. Esse fato reforça a melhoria do cozimento por entrada de água ou enfraquecimento das paredes celulares. 
Pode-se dizer que o congelamento das raízes não aumentou o tempo de cocção das mesmas, considerando que foi utilizado apenas o tempo considerado ideal para cocção (16 minutos para plantas de 12 meses e 21 minutos para plantas de 15 meses), foi possível tanto descongelar como cozer as raízes, que ainda apresentaram textura mais macia.

Este resultado contrasta com o observado por Pequeno et al. (1991), onde raízes congeladas das variedades de mandioca Pão do Chile e Baiana apresentaram aumento significativo no tempo de cocção quando comparado com raízes frescas.

$\mathrm{O}$ congelamento afetou a textura das raízes de plantas em ambas as idades. Após este tratamento as plantas com 12 e com 15 meses não apresentaram diferença significativa entre si quanto à resistência das raízes ao cisalhamento.

A análise de textura realizada no texturômetro TA.XT2 (Figuras 19 e 20 e Tabela 10) mostrou que raízes de plantas com 12 meses de idade apresentaram menor dureza que aos 15 meses, confirmando o resultado pelo Texture Testing System. Pelo texturômetro TA.XT2, onde foram efetuadas 12 repetições, ficou evidente a grande variabilidade existente entre as raízes de um mesmo tratamento quanto à textura, fato que pode ser percebido pelos valores de desvio padrão mostrados na Tabela 10 e razão pela qual foi apresentado nas Figuras 20 e 21 as curvas médias de ambas as repetições.

A presença do segundo pico em uma das curvas das raízes de plantas com 15 meses (Figura 21) durante o ciclo de compressão da amostra podem decorrer da presença nessas amostras de pequenos grumos, mais duros.

Além do parâmetro dureza, a qualidade de massa cozida foi avaliada quanto ao parâmetro adesividade. O resultado negativo demonstra a resistência adesiva da amostra junto ao probe do instrumento, quando esse realiza o movimento de retorno após a compressão. Esses valores foram menos intensos se comparados com os valores de dureza, entretanto, mostraram-se mais evidentes nas raízes cozidas das plantas com 12 meses do que nas de 15 meses.

Pelos resultados obtidos, pode se observar que houve diferença no tempo de cocção e nas características texturais apresentadas pelas raízes cozidas de plantas nas diferentes idades. 


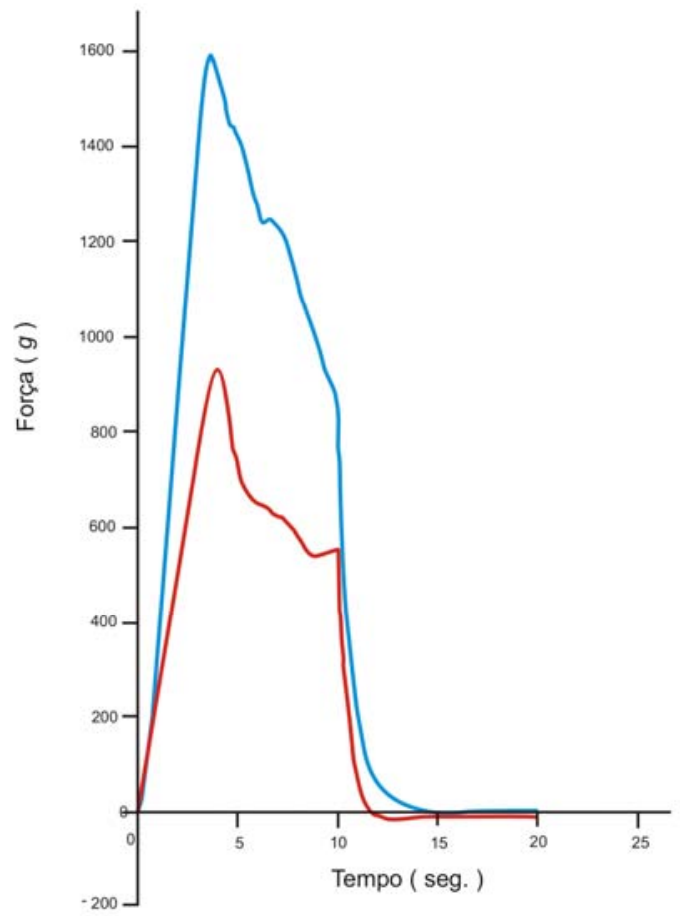

Figura 19 - Curvas obtidas pelo texturômetro TA.XT2 para raízes de mandioca de plantas com 12 meses de idade

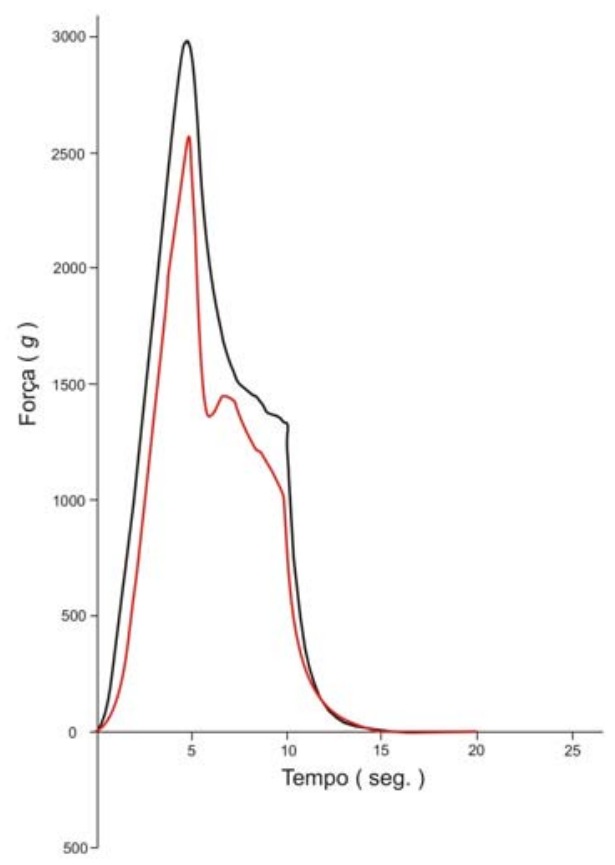

Figura 20 - Curvas pelo texturômetro TA.XT2 para raízes de mandioca de plantas com 15 meses de idade 


\subsection{Análise sensorial das raízes}

As notas médias dos provadores obtidas mediante teste de aceitabilidade das raízes cozidas de plantas de mandioca em ambas as idades encontram-se na Tabela 11.

Tabela 11. Notas dos provadores pela escala hedônica para avaliação global das raízes cozidas de plantas com 12 e 15 meses de idade

\begin{tabular}{rc}
\hline Raízes & $\begin{array}{c}\text { Média e desvio padrão das notas dos } \\
\text { provadores }\end{array}$ \\
\hline Plantas com 12 meses & $8,0^{\mathrm{a}} \pm 0,77$ \\
Plantas com 15 meses & $6,0^{\mathrm{b}} \pm 1,2$ \\
\hline
\end{tabular}

Nota: médias com letras diferentes diferem entre si em nível de 5\% de probabilidade pelo teste de Tukey

As amostras cozidas das raízes de plantas com 12 meses de idade receberam média igual a 8,0, equivalente a gostei muito. Já as amostras cozidas das raízes de plantas com 15 meses de idade receberam média igual a 6,0, referente a gostei ligeiramente. A maior parte das observações feitas pelos provadores foi com relação à textura das raízes. As raízes de plantas com 12 meses de idade foram descritas como mais macias e que desmancham na boca. Já as amostras de raízes de plantas com 15 meses de idade foram descritas como muito secas, pouco macias, esfarelentas e mais rígidas e ainda alguns identificaram alguns grânulos mais duros.

Os resultados obtidos para textura por métodos instrumentais (objetivos) coincidiram com estes resultados subjetivos da análise sensorial das raízes de mandioca. A descrição das raízes de plantas aos 15 meses pelos painelistas evidenciou o que parâmetros avaliados anteriormente já haviam exposto, ou seja, demoram mais para cozer, apresentam menor desintegração celular durante a cocção, maior dureza das 
raízes, valores mais elevados de viscosidade, teores mais elevados de amido e de fibras e ainda, grânulos de amido de tamanho maior.

No caso de batata inglesa, as características da massa cozida têm apresentado correlações com o teor e características do amido presente nos tubérculos, sendo que quanto maior o teor de amido e maior o tamanho dos grânulos, maior a farinosidade do tubérculo (Krokida et al., 2001; Briant et al., 1945; Bu-Contreras \& Rao, 2002). 


\section{CONCLUSÕES}

Nas condições do presente trabalho as raízes de mandioca do cultivar IAC 576-70 apresentaram algumas características significativamente diferentes entre as idades ou os momentos fisiológicos estudados. Não se pode concluir genéricamente se estas diferenças foram decorrentes da idade ou da fisiologia do vegetal; alguns comportamentos são melhor explicados pela idade, outros pela fisiologia vegetal.

$\Leftrightarrow$ Raízes de plantas de mandioca com 12 meses de idade (período vegetativo) apresentaram menor tempo de cocção e melhor qualidade de massa cozida que as raízes de plantas com 15 meses (período de repouso).

$\Leftrightarrow$ As raízes de plantas de mandioca com 12 meses de idade apresentam maior porcentagem de desintegração celular durante o cozimento, menor dureza, tanto no material cru como cozido, maior adesividade no material cozido e maior aceitação pelos provadores na análise sensorial que as raízes das plantas com 15 meses de idade.

$\Leftrightarrow$ O congelamento diminuiu a resistência das raízes cozidas ao cisalhamento em ambas as idades, que não mais apresentaram diferença significativa entre si.

$\stackrel{\leftrightarrow}{\rightarrow}$ As raízes de plantas aos 12 meses (menor tempo de cocção) apresentaram menores teores de amido e de fibras totais e maiores teores de carboidratos redutores, de proteína, de lipídeos e de substâncias pécticas.

$\Leftrightarrow$ Os teores dos minerais cálcio, magnésio e potássio nas raízes de ambas as idades não apresentaram diferença estatística entre si.

$\Leftrightarrow$ O teor de amilose dos amidos extraídos de raízes de plantas nas idades estudadas não variou significativamente, entretanto, nas raízes de menor tempo de coç̧ão (plantas com 12 meses) o tamanho médio dos grânulos foi menor e maior amplitude de variação 
de tamanho foi maior, provavelmente em decorrência do momento fisiológico do vegetal. Quanto às propriedades de pasta do amido, nas plantas com 12 meses foi observado menor pico de viscosidade e pico mais arredondado que o obtido para amido extraído de raízes de plantas com 15 meses.

$\Leftrightarrow$ Os testes histoquímicos não revelaram diferenças expressivas entre as raízes de plantas de menor ou maior tempo de cocção, tanto nas amostras cruas como nas cozidas. Foi detectada a presença de pectina na lamela média das raízes, lignina apenas nos vasos condutores e substâncias lipídicas na parede celular de raízes cruas e nas células e parede celular de raízes cozidas. Compostos fenólicos não foram detectados.

$\stackrel{M}{\rightarrow}$ Os viscoamilogramas (RVA) das raízes cozidas, desidratadas e moídas de plantas aos 12 e aos 15 meses mostraram comportamentos opostos comparativamente aos respectivos viscoamilogramas do material cru. 


\section{REFERÊNCIAS BIBILIOGRÁFICAS}

ALBUQUERQUE, T.T.O.; MIRANDA, L.C.G.; SALIM, J.; TELES, F.F.F.; QUIRINO, J.G. Composição centesimal da raiz de 10 variedades de mandioca (Manihot esculenta Crantz) cultivadas em Minas Gerais. Revista Brasileira da Mandioca, v.12, n.1, p.7-12, jan. 1993.

ASSOCIATION OF OFFICIAL ANALYTICAL CHEMISTS (AOAC). Official Methods of Analysis of the Association of Official Analytical Chemists. 16.ed. Arlington, 1995. 2v.

ASP, N.G.; JOHANSSON, C.G.; HALLMER, H.; SILJESTRÖM, M. Enzymatic assay of insoluble and soluble dietary fiber. Journal of Agriculture and Food Chemistry, v.31, n.3, p.476-482, Mar. 1983.

BARTOLOME, L.G.; HOFF, J.E. Firming of potatoes: biochemical effects of preheating. Journal of Agricultural and Food Chemistry, v.20, n.2, p.266-270, Mar./Apr. 1972.

BHATTY, R.S. Comparisons of good-and poor-cooking lentils. Journal of the Science of Food and Agriculture, v.68, n.2, p.489-496, Feb. 1995. 
BINNER, S.; JARDINE, W.G.; RENARD, C.M.C.G.; JARVIS, M.C. Cell wall modifications during cooking of potatoes and sweet potatoes. Journal of the Science of Food and Agriculture, v.80, n.2, p.216-218, Jan. 2000.

BLANSHARD, J.M.V. Starch granule structure and function. In: GALLIARD, T. (Ed.). Starch: properties and potential. London: Society of Chemical Industry/John Wiley \& Sons, 1987. p.16-54. (Critical reports on applied chemistry, 13).

BOBBIO, P.A.; BOBBIO, F.O. Química do processamento de alimentos. São Paulo: Varela, 1992. 156p.

BRETT, C.T.; WALDRON, K.W. Physiology and biochemistry of plant cell walls. 2.ed. London: Champman \& Hall, 1996. 255p.

BRIANT, A.M.; PERSONIUS, C.J.; CASSEL, E.G. Physical properties of starch from potatoes of different culinary quality. Food Research, v.10, n.5, p.437-444, Sep./Oct. 1945.

BROWNLEADER, M.D.; JACKSON, P.; MOBASHERI, A.; PANTELIDES, A.T.; SUMAR, S.; TREVAN, M.; DEY, P.M. Molecular aspects of cell wall modifications during fruit ripening. Critical Reviews in Food Science and Nutrition, v.39, n.2, p.149-164, Feb. 1999.

BRUCE, A. (Ed.). Biologia molecular da célula. Porto Alegre: Artes Médicas, 1997. 469 p.

BU-CONTRERAS, R.; RAO, M.A. Review: dynamic rheological behavior of heated potatoes. Food Science and Technology International, v.8, n.1, p.3-10, Feb. 2002. 
CAMPOS, S.D.S. Textura de alimentos. In: CAMPOS, S.D.S.; GONÇALVES, J.R.; MORI, E.E.M.; GASPARETTO, C.A. Reologia e textura de alimentos. Campinas: ITAL, 1989. p.12-16.

\section{CHEFTEL, J.C.; CHEFTEL, H. Introduccion a la bioquimica y tecnologia de los} alimentos. 2.ed. Zaragoza: Acribia, 1992. v.1.

CUTTER, E.G. Anatomia vegetal: células e tecidos. 2.ed. São Paulo: Roca, 2002. $304 p$.

DAIUTO, E.R. Desenvolvimento dos grânulos de amido durante o crescimento secundário das raízes de mandioca das cultivares Mico e Branca de Santa Catarina. Botucatu, 2000. 140p. Dissertação (Mestrado) - Faculdade de Ciências Agronômicas, Universidade Estadual Paulista "Júlio de Mesquita Filho".

DAMIÃO FILHO, C.F. Morfologia vegetal. Jaboticabal: Funep/UNESP, 1993. 144p.

DI-TANNO, M.F.P. Influência da temperatura, tempo e concentração de pectinase na textura, rendimento e características físico-química da mandioca (Manihot esculenta C.) durante fermentação. Piracicaba, 2001. 105p. Dissertação (Mestrado) - Escola Superior de Agricultura "Luiz de Queiroz”, Universidade de São Paulo.

EGGLESTON, G.; ASIEDU, R. Effects of boiling on the texture of cassava clones: a compararison of compressive strength, intercellular adhesion and physicochemical composition of the tuberous roots. Tropical Science, v.34, n.3, p.259-273, Mar. 1994.

FAO. Statistical datas: http://apps.fao.org/cgi-bin/nph-db.pl (24 Apr. 2003) 
FAVARO, S.P. Composição química e estrutura de paredes celulares de variedades de mandioca (Manihot esculenta Crantz) com tempos de cocção diferentes. Londrina, 2003. 132p. Tese (Doutorado) - Centro de Ciências Agrárias, Universidade Estadual de Londrina.

GALLIARD, T.; BOWLER, P. Morphology and composition of starch. In: GALLIARD, T. (Ed.) Starch: properties and potential. Society of Chemical Industry/John Wiley \& Sons, 1987. p.55-78. (Critical reports on applied chemistry, 13).

GÓMEZ, G.; VALDIVIESO, M.; NOMA, A.T. The influence of cultivar and plant age on the chemical composition of field-grown cassava leaves an roots. Plant Foods of Humany Nutricion, v.35, n.2, p.109-119, Feb. 1985.

INTERNATIONAL ORGANIZATION FOR STARDARDIZATION. Norme internationale: rizdétermination de la teneur en amylose. 1987. ISO 6647.

JASWAL, A.S. Texture of french fried potato, chemical composition of non-starch polysaccharides. American Potato Journal, v.66, n.12, p.835-841, Dec. 1989.

JENSEN, W.A. Botanical histochemistry: principles and practice. San Francisco: Freeman, 1962. 408p.

JOHANSEN, D.A. Plant microtechnique. New York: McGraw-Hill, 1940. 528p.

KAWANO, K.; FUKUDA, W.M.G. Genetic and environmental effects on dry matter content of cassava root. Crop Science, v.27, n.1, p.69-74, 1987. 
KATO, M.S.A.; CARVALHO, V.D.; CORRÊIA, H.; PINTO, J.E.B.P. Efeito da poda na deterioração fisiológica e na qualidade de raízes de mandioca. Ciência Prática, v.11, n.1, p.75-84, jan. 1987.

KROKIDA, M.K.; OREOPOULOU, V.; MAROULOIS, Z.B.; MARINOS-KOURIS, D. Viscoelastic behaviour of potato strips during deep fat frying. Journal of Food Engineering, v.48, n.3, p.213-218, May 2001.

LINEBACK, D.R. Textural attributes of carbohydrate: rich foods as influenced by chemical reactions during processing. In: FENNEMA, O.R.; CHANG, W.H.; LII, C.Y. Role of chemistry in the quality of processed food. Westport: Food \& Nutrition Press, 1986. p.290-302.

LORENZI, J.O. Variação na qualidade culinária das raízes de mandioca. Bragantia, v.53, n.2, p.237-245, fev. 1994.

LORENZI, J.O.; DIAS, C.A.C. Cultura da mandioca. Campinas: Coordenadoria de Assistência Técnica Integral, 1993. 41p.

MARLE, J.T. van; RECOURT, K.; DIJK, C. van; SCHOLS, H.A.; VORAGEN, G.J. Structural features of cell walls from potato (Solanum tuberosum L.) cultivars Irene and Nicola. Journal of Agricultural and Food Chemistry, v.45, n.5, p.1686-1693, May 1997.

McCREADY, R.M.; McCOMB, E.A. Extraction and determinatios of total pectic materials in fruits. Analytical Chemistry, v.24, n.12, p.1586-1588, Dec. 1952.

MINITAB. Minitab Release 14. http://www.minitab.com (05 Oct. 2003) 
MIRANDA, L.A. Características tecnológicas, agronômicas e de qualidade de mandioca de mesa. Londrina, 2000. 152p. Tese (Doutorado) - Centro de Ciências Agrárias, Universidade Estadual de Londrina.

MORAES-DAllaQUA, M.A. de.; CORAL, D.J. Morfo-anatomia. In: CEREDA, M. P. (Coord.). Agricultura: tuberosas amiláceas latino-americanas. São Paulo: Fundação Cargill, 2002. 540p. (Série: culturas de tuberosas amiláceas latinoamericanas, 2)

NASCIMENTO, L.M. Efeito da radiação gama $\left(\mathrm{Co}^{60}\right)$ nas propriedades físico-químicas e sensoriais de feijões envelhecidos (Phaseolus vulgaris, L.). São Paulo, 1992. 147p. Tese (Doutorado) - Faculdade de Ciências Farmacêuticas, Universidade de São Paulo.

NEWPORT SCIENTIFIC. Operation manual for series 4: instructions manual. Warriewood, 1998. 123p.

NG, A.; WALDRON, K.W. Effect of steaming on cell wall chemistry of potatoes (Solanum tuberosum) in relation to firmness. Journal of Agricultural and Food Chemistry, v.45, n.9, p.3411-3418, Aug. 2002.

NORMANHA, E.S. O mau cozimento dos aipins: uma hipótese. O Agronômico, v.40, n.1, p.13-14, jan./abr. 1988.

NULTSCH, W. Botânica geral. 10.ed. Porto Alegre: Artes Médicas Sul, 2000. 489p.

ONG, M.H.; BLANSHARD, J.M.V. Texture determinants in cooked, parboiled rice. I: rice starch amylose and the fine stucture of amylopectin. Journal of Cereal Science, v.21, n.3, p.251-260, Mar. 1995. 
PARKER, M.L.; WALDRON, K.W. Texture of chinese water chestnut: involvement of cell wall phenolics. Journal of the Science of Food and Agridulture, v.68, n.1, p.337-346, Jan. 1995.

PEQUENO, M.G.; COSTA, L.; CHAGAS, S.J. de R. Efeito do congelamento no tempo de cocção e em alguns componentes químicos das raízes de sete cultivares de mandioca. Revista Brasileira de Mandioca, v.10, n.1-2, p.81-85, jun. 1991.

PEREIRA, A.S.; LORENZI, J.O.; VALLE, T.L. Avaliação do tempo de cozimento e padrão de massa cozida em mandioca de mesa. Revista Brasileira de Mandioca, v.4, n.1, p.27-32, jun. 1985.

PEREIRA, L.T.P.; BELÉIA, A. del P. Isolamento, fracionamento e caracterização de paredes celulares de raízes de mandioca (Manihot esculenta Crantz). Ciência e Tecnologia de Alimentos, v.24, n..1, p.59-63, jan./mar. 2004.

PERIAGO, M.J.; ROS, G.; LÓPEZ, G.; MARTÍNEZ, M.C.; RINCÓN, F. Componentes de la fibra dietética y sus efectos fisiológicos. Revista Española de Ciencia y Tecnología de Alimentos, v.33, n.3, p.229-246, Mar. 1993.

PETERSEN, D.G.; FULCHER, R. . Variation in Minnesota HRS wheats: starch granule size distribution. Food Research International, v.34, n.4, p.357-363, Apr. 2001.

POSTE, L.M.; MACKIE, D.A.; BUTLER, G.; LARMOND, E. Laboratory methods for sensory analysis of food. Ottawa: Canada Communication Group, 1991. 90p.

POSTO AGROMETEREOLÓGICO DA ESALQ. Dados metereológicos. http://www.ciagri.usp.br/ emdabreu/MEDIAS.TXT (03 jun. 2004) 
POTTER, A.L.; McCOMB, E.A. Carbohydrate composition of potatoes: pectin content. American Potato Journal, v.34, n.12, p.342-346, Dec. 1957.

RAVEN, P.H.; EVERT, R.F.; EICHHORN, S.E. Biologia vegetal. 6.ed. Rio de Janeiro: Guanabara Koogan, 2001. 906p.

RICKARD, J.E.; BEHN, K.R. Evaluation of acid and enzyme hidrolytic methods for the determination of cassava starch. Journal of Science of Food and Agriculture, v.41, n.4, p.373-379, Apr. 1987.

RICKARD, J.E.; ASAOKA, M.; BLANSHARD, J.M.V. The physicochemical properties of cassava starch. Tropical Science, v.31, n.4, p.189-207, Apr. 1991.

ROSENTHAL, F.R.T. A cultura da mandioca. Informativo do Instituto Nacional de Tecnologia, v.10, n.1, p.27-36, jan. 1976.

SAFO-KANTANKA, O.; OWSU-NIPAH, J. Cassava varietal screening for cooking quality: relationship between dry matter, starch content, mealiness and certain microscopic observations of the raw and cooked tuber. Journal of Science of Food and Agriculture, v.60, n.1, p.99-104, Jan. 1992.

SARMENTO, S.B.S. Caracterização da fécula de mandioca (Manihot esculenta C.) no período de colheita de cultivares de uso industrial. São Paulo, 1997. 176p. Tese (Doutorado). Faculdade de Ciências Farmacêuticas, Universidade de São Paulo.

SARRUGE, J.R.; HAAG, H.P. Análises químicas em plantas. Piracicaba: USP/ ESALQ, 1974. 56p.

SOMOGY, M. A new reagent for the determination of sugars. The Journal of Biological Chemistry, v.160, n.1, p.61-68, Jan. 1945. 
STERLING, C. Texture and cell-wall polysaccharides in foods. In: LEITCH, J. M.; RHODES, D.N. (Ed.). Recent advances in food science. London: Britter Worths, 1963. p.259-281. v.3: Biochemistry and biophysycs in food research.

STERLING, C.; BATTELHEIM, F.A. Factors associated with potato texture. III: physical attributes and general conclusions. Food Research, v.20, n.2, p.130-137, Mar./Apr. 1955.

STOLLE-SMITS, T.; BEEKHUIZEN, J.G.; DIJK, C. van; VORAGEN, A.G.J.; RECOURT, K. Cell wall dissolution during industrial processing of green beans (Phaseolus vulgaris L.). Journal of Agricultural and Food Chemistry, v.43, n.9, p.2480-2486, Sep. 1995.

STOLLE-SMITS, T.; BEEKHUIZEN, J.G.; RECOURT, K.; VORAGEN, A.G.J.; DIJK, C. van. Changes in pectic and hemicellulosic polymers of green beans (Phaseolus vulgaris L.) during industrial processing. Journal of Agricultural and Food Chemistry, v.45, n.12, p.4790-4799, Dec. 1997.

TERNES, M. Fisiologia da planta. In: CEREDA, M. P. (Coord.). Agricultura: tuberosas amiláceas latino-americanas. São Paulo: Fundação Cargill, 2002. 540p. (Série: culturas de tuberosas amiláceas latino - americanas,2)

THOMAS, D.J.; ATWELL, W.A. Starches. Saint Paul: s. ed. 1999. 94p.

VAlETUDIE, J.C.; GALlANT, D.J.; BOUCHET, B.; COLONNA, P.; CHAMP, M. Influence of cooking procedures on structure and biochemical changes in sweet potato. Starch/Stärke, v.51, n.11-12, p.389-397, Nov./Dec. 1999. 
VILPOUX, O.; CEREDA, M.P. Processamento de raízes e tubérculos para uso culinário minimamente processadas, pré-cozidas, congeladas e fritas (french-fries). In: CEREDA, M. P.; VILPOUX, O. (Coord.). Tecnologia, usos e potencialidades de tuberoses amiláceas latino-americanas. São Paulo: Fundação Cargill, 2003. p. 81-131. (Série culturas de tuberosas amiláceas latino-americanas, 3).

WALDRON, K.W.; SMITH, A.C.; PARR, A.J.; NG, A.; PARKER, M.L. New approaches to understanding and controlling cell separation in relation to fruit and vegetable texture. Trends in Food Science \& Technology, v.25, n.1, p.213-221, Jan. 1997.

WARREN, D.A.; WOODMAN, J.S. The texture of cooked potatoes, a review. Journal of Science of Food and Agriculture, v.25, n.2, p.129-138, Feb. 1974.

WHISTLER, R.L.; BeMILLER, J.N. Carbohydrate chemistry for food scientists. Saint Paul: Eagan Press, 1999. 241p.

WHISTLER, R.L.; DANIEL, J.R. Carbohidratos. In: FENNEMA, O.R. Química de los alimentos. Zaragoza: Acribia, 1993. p.81-156.

ZENG, M.; MORRIS, C.F.; BATEY, I.L.; WRIGLEY, C.W. Sources of variation for starch gelatinization, pasting, and gelation properties in wheat. Cereal Chemistry, v.74, n.1, p.63-71, Jan. 1997. 